Pontifícia Universidade Católica $_{\text {a }}$

DO RIO DE JANEIRO

Mayra Terra Maluf de Araujo

Objetos de Design, Peças Artesanais e Obras de Arte: Similaridades e distinções das Práticas Criativas

Dissertação de Mestrado

Dissertação apresentada ao Programa de Pós-graduação em Design da PUC-Rio como requisito parcial para obtenção do grau de Mestre em Design.

Orientador: Prof. Alberto Cipiniuk

Co-orientadora: Profa. Irina Aragão dos Santos

Rio de Janeiro

Dezembro 2018 
Mayra Terra Maluf de Araujo

\section{Objetos de Design, Peças Artesanais e Obras de Arte: Similaridades e distinções das Práticas Criativas}

Dissertação apresentada ao Programa de Pós-graduação em Design da PUC-Rio como requisito parcial para obtenção do grau de Mestre em Design. Aprovada pela Comissão Examinadora abaixo assinada.

Prof. Alberto Cipiniuk

Orientador

Departamento de Artes \& Design - PUC-Rio

Profa. Irina Aragão dos Santos

Co-orientadora

Departamento de Artes \& Design - PUC-Rio

Prof. Carlos Eduardo Felix da Costa

Departamento de Artes \& Design - PUC-Rio

Profa. Fabiana Oliveira Heirich

Profa. Monah Winograd

Coordenadora Setorial do Centro de Teologia e Ciências humanas - PUC-Rio

Rio de Janeiro, 14 de dezembro de 2018 
Todos os direitos reservados. É proibida a reprodução total ou parcial do trabalho sem autorização da universidade, da autora e do orientador.

\section{Mayra Terra Maluf de Araujo}

Graduou-se em Design - Projeto de Produto na Puc - Rio (Pontifícia Universidade Católica do Rio e Janeiro) em 2014. Possui experiencia como designer de figurinos e em elaboração de projetos de design gráfico e ilustração.

Ficha Catalográfica

Araujo, Mayra Terra Maluf de

Objetos de design, peças artesanais e obras de arte : similaridades e distinções das práticas criativas / Mayra Terra Maluf de Araujo ; orientador: Alberto Cipiniuk ; co-orientadora: Irina Aragão dos Santos. -2018.

132 f. : il. color. ; $30 \mathrm{~cm}$

Dissertação (mestrado)-Pontifícia Universidade Católica do Rio de Janeiro, Departamento de Artes e Design, 2018.

Inclui bibliografia

1. Artes e Design - Teses. 2. Campo do design. 3. Campo da arte. 4. Campo do artesanato. 5. Fronteiras. 6.Criatividade. I. Cipiniuk, Alberto. II. Santos, Irina Aragão dos. III. Pontifícia Universidade Católica do Rio de Janeiro. Departamento de Artes e Design. IV. Título. 


\section{Agradecimentos}

Agradeço ao meu orientador Prof. Alberto Cipinuk pela parceria ao longo de toda a produção deste trabalho e pelo incentivo constante no desenvolvimento de um pensamento crítico e uma formação intelectual.

Agradeço a PUC-Rio pela possibilidade de desenvolvimento desta pesquisa de pós-graduação e igualmente ao Departamento de Artes e Design. O presente trabalho foi realizado com apoio da Coordenação de Aperfeiçoamento de Pessoal de Nível Superior - Brasil (CAPES) - Código de Financiamento 001.

Agradeço a minha amiga e professora Irina Aragão, que sempre foi extremamente presente na minha formação tanto na graduação quanto na pós-graduação, como amiga, professora e orientadora.

Agradeço aos membros da banca, Irina Aragão, Cadu, Fabiana Heinrich e Fernanda Cardoso por compartilharem comigo a resolução deste trabalho e suas considerações sobre ele.

Aos meus colegas dos grupos de estudos GRUDAR e LINDA por semanalmente trocarem ideias, conhecimentos e opiniões comigo.

Aos artesãos e artistas pernambucanos pelo trabalho que realizam e pelas conversas que tiveram comigo e me inspiraram e ajudaram a construir esta dissertação.

Aos meus pais, Heloisa e Ive, por terem me apoiado e me estimulado em tudo que desejei construir até hoje.

Ao Marty Kaleta, a Carol Bergallo, ao Victor Bezerra, a Duda Gaia e ao Raphael Pegden por serem tão próximos, pacientes e companheiros em todos os momentos. 


\section{Resumo}

Araujo, Mayra Terra Maluf; Alberto, Cipiniuk (Orientador). Objetos de Design, Peças Artesanais e Obras de Arte: Similaridades e distinções das Práticas Criativas. Rio de Janeiro, 2018. 132p. Dissertação de Mestrado - Departamento de Design, Pontifícia Universidade Católica do Rio de Janeiro.

Esta pesquisa tem como objetivo realizar um estudo acerca das fronteiras entre o Campo do Design, o Campo da Arte e o Campo do Artesanato. Compreendemos que ambos se encontram por serem percebidos hegemonicamente como profissões resultantes de uma prática criativa, e desse modo analisaremos quais as semelhanças e distinções entre os produtos ou mercadorias que circulam entre nós e como são legitimados para o consumo. Com base no que se entende hoje por criatividade, conduziremos uma argumentação pautada na figura do artista e na construção histórica da crença do gênio criativo e autônomo. Em uma sociedade cuja a estrutura fundamental de consumo é capitalista, desejamos localizar a inserção do artista, do designer e do artesão neste cenário comercial. Analisaremos também o que é tido como cultura erudita e cultura popular, em razão de que essas noções estão intimamente conectadas com as práticas profissionais em questão. Do mesmo modo, examinaremos o valor de uso e o valor de troca simbólica dos objetos, entre o público consumidor e nos espaços destinados a venda e a exposição das obras de arte, das peças de artesanato e dos objetos de design. Esta pesquisa se desenvolve em um contexto brasileiro e apresentaremos uma investigação empírica realizada com artesãos, artistas e designers nos estados de Pernambuco, Paraíba e Alagoa. Enfim, desejamos verificar como se constituem as diferenciações simbólicas destes objetos tidos como especiais em relação aos demais, e como podemos estabelecer classificações que possam distinguir cada campo específico e os profissionais que neles atuam.

\section{Palavras Chave}

Campo do Design; Campo da Arte; Campo do Artesanato; Cultura Erudita; Cultura Popular; Criatividade; Fronteira; Autonomia; Consumo; Legitimação. 


\section{Abstract}

Araujo, Mayra Terra Maluf; Alberto, Cipiniuk (Advisor). Objects of Design, Handicrafts, and Works of Art: Similarities and Distinctions of the Creative Practices. Rio de Janeiro, 2018. 132p. Dissertação de Mestrado - Departamento de Design, Pontifícia Universidade Católica do Rio de Janeiro.

This project analyzes the boundaries between the Field of Design, the Field of Art, and the Field of Handicrafts. We understand that each is hegemonically perceived as a profession resulting from a creative practice and we will analyze the similarities and differences between the products or goods circulating among us and how they are legitimized for consumption. Based on what is known today about creativity, we will lead an argument based on the role of the artist and the historical construction of the creative and autonomous genius. In a society whose fundamental structure of consumption is capitalist, we aim to locate the insertion of the artist, designer, and artisan in this commercial setting. We will also analyze what is considered erudite culture and popular culture as these concepts are closely connected to the professional practices in question. Similarly, we will examine the value of use and the value of symbolic exchange of objects within the consumer public and the spaces intended for selling and exhibiting the works of art, handicrafts, and design objects. The research focuses on the Brazilian context as we will present an empirical investigation conducted with artisans, artists, and designers in the states of Pernambuco, Paraíba and Alagoa. Finally, we aim to verify how the symbolic differentiation of these objects is considered special compared to others and how we can establish classifications that can distinguish each field and the professionals who work within them.

\section{Keywords}

Field of Design; Field of Art; Field of Artisan; Erudite Culture; Popular Culture; Creativity; Borders/Boundaries; Autonomy; Consumption; Legitimization; 


\section{Sumário}

1. Introdução

2. As Crenças e Fundamentos das Práticas Criativas 23

2.1. O Conceito de Criatividade no Design e na Arte 28

2.2. O Trabalho Coletivo e as Expressões Individuais do Criador Moderno

2.3. A Cultura Erudita e a Cultura Popular - Uma Visão a Partir das Definições de Canclini

3. As Relações Fronteiriças na Produção de Objetos - O Design, A Arte e o Artesanato como Elementos de Comparação

3.1. As Intercessões e Dissemelhanças Simbólicas dos Objetos Industriais, das Peças de Artesanato e das Obras de Arte 63

3.2. A Produção Interiorana do Artesanato e as Feiras Regionais

3.3. Comunicação Visual e Artes Gráficas - uma visão das práticas pelos profissionais atuantes

4. Conclusão

5. Referências bibliográficas 


\section{Lista de Figuras}

Figura 1 - The Golden Calf, Demian Hirst.

Figura 2 - Juice Salif, Phillipe Starck - Espremedor de laranjas desenvolvido pelo designer Felipe Starck

Figura 3 - Artesanatos produzidos na llha do Ferro - AL

Figura 4 - Artesanatos produzidos na llha do Ferro - AL

90

Figura 5 - Oficina de trabalho do artesão José Bezerra no Vale do Catimbau - PE

Figura 6 - Oficina de trabalho do artesão Luiz Benício no Vale do Catimbau - PE

Figura 7 - Cartaz desenvolvido por Raoni Assis para o festival RecBeat de 2015

Figura 8 - Cartaz desenvolvido por Shiko para o festival RecBeat de 2013

Figura 9 - Cartaz desenvolvido por Ayode França para o Festival RecBeat de 2017 


\section{Introdução}

Consumir tipos distintos de mercadorias, isto é, a troca de dinheiro por um objeto fabricado, seja ele um objeto de design, objeto de arte ou um objeto de artesanato, é uma ação humana profundamente enraizada e corriqueira na sociedade contemporânea. A diferenciação entre o consumo e a produção dos objetos se dá de forma mais óbvia pelos distintos meios de fabricação que eles possuem, podendo ser industrial, semi-industrial ou artesanal. Entretanto este não é o único ponto que eles se apartam.

A forma como os brasileiros se relacionam hoje com as mais diversas mercadorias ou produtos exige dos pesquisadores uma reflexão pautada em algumas crenças preconcebidas e institucionalizadas sobre esses objetos que consumimos, pois são exatamente essas crenças que definem o valor simbólico dos objetos. Assim, se verifica que há uma discussão, ainda que silenciosa, de como se dá ou se classifica o valor cultural de um objeto, pois para nós há objetos mais importantes do que outros.

Em nossa sociedade, seja pelo valor de uso ou pelo valor de troca simbólica, verifica-se que por conta do capitalismo tendemos a perceber simbolicamente apenas aquilo que é agregado financeiramente aos objetos ou mercadorias que nos cercam. Tudo indica que em geral esquecemos de tratar de outras formas simbólicas que não sejam aquelas que consideram a troca de um objeto por certa quantidade de dinheiro. Saber quanto custa isso ou aquilo é dar um valor simbólico para alguma coisa, mas preocupamo-nos em emular essa tradição com outras e talvez mais antigas, mas igualmente válidas. E, ao tratar do consumo de bens materiais, desejamos sustentar que nos referimos às variedades mais diversas disso que se compreende mercadorias, que de modo geral abrange um leque incalculável de objetos.

Apesar de sermos condicionais ao remeter a palavra produto para "coisas" com uma funcionalidade explícita ou não, sustentamos que é necessário que se mensure que os objetos tidos como artísticos ou culturais como satélites do grande planeta chamado bens de consumo. Nós, como seres sociais que somos, estamos constantemente cercados por objetos que nos transmitem simbologias e 
usos diferentes. Desse modo, podemos mapear rapidamente alguns destes bens de consumo que nos cercam e que são bastante distintos tanto em função, quanto em entendimento de importância, isto é, que possuam valor simbólico ou não. Então, para exemplificarmos rapidamente quão diversos podem ser esses produtos ou mercadorias, consideraremos um "usuário"1 contemporâneo ocidental, vivendo em um país da periferia do capitalismo neoliberal, que em um período de poucas horas após acordar já fez uso de roupas, sabonete, pão francês, pasta de dente, da máquina de café ou filtro de papel, uma caneca de barro com grafismo marajoara artesanal comprada em uma feira de arte popular, de um telefone celular, de uma música, um livro, sapatos e assim por diante. Desse conjunto de objetos, consideramos aqui que o livro e a música são "objetos de arte", isto é, que envolvem de algum modo o termo arte e, como "objeto artesanal" o pão francês e a caneca estilo marajoara. Assim como, verificamos que eles são produzidos semiindustrialmente. Ou outros são totalmente industriais.

As possíveis considerações que podemos apresentar tanto em relação ao valor de uso quanto do valor simbólico agregado de um filtro de papel, uma camiseta e uma música são absolutamente distintos. Fundamentalmente eles se opõem quanto a materialidade plena de uma camiseta ou do filtro de papel apesar da distinção quanto a vida útil de cada um - e a imaterialidade da música escutada virtualmente. Porém, de todo modo, ambos se assemelham em um ponto: quando pensamos que se trata de bens de consumo, embora apresentem distinções significativas nos seus processos de produção ou fabricação, distribuição e comercialização, todos são mercadorias, isto é, são trocados por dinheiro.

A todo momento estão se fabricando mais e mais utensílios, roupas, músicas, filmes, carros, pão francês, obras de arte, satélites, armas, refrigerantes, santos em madeira, remédios, canudos descartáveis, canetas e tudo aquilo que nos cerca cotidianamente, mercadorias que na falta de melhor juízo, acreditamos possuírem valor de uso. Nosso consumo desenfreado de bens tão diferentes serve de suporte ou estrutura para a reprodução e ampliação da sociedade industrial tal

\footnotetext{
${ }^{1}$ Embora usuário seja um termo dicionarizado e razoavelmente empregado na língua portuguesa, é também o termo técnico empregado pelos pares do Campo do Design para nomear o público consumidor. Os usuários são aqueles que foram inculcados pela noção de que um objeto projetado por um designer é mais útil do que um que não foi. Essa noção é sistematicamente legitimada pelos pares do campo e reproduzida e ampliada regularmente nos bancos escolares das instituições de ensino do design. O mesmo ocorre no meio social em geral por intermédio da mídia, exposições, certames etc.
} 
como a conhecemos hoje. Nossa economia é baseada em um modo de produção capitalista e também desenvolve uma apologia para obtenção desses bens materiais fabricados pela indústria. Porém a diferenciação essencial entre as categorias de produtos se reduz a um critério apenas, um critério que os agrupa de tal modo que constituímos uma percepção distinta sobre eles e hegemonicamente hierarquizamos aquilo que acreditamos ser mais importante ou mais superficial, bem como atribuímos juízos de valor intimamente ligados ao preço, à estética e à funcionalidade. Enfim, embora estejamos enumerando três categorias de análise, elas se confundem no critério econômico. Se compararmos o filtro de papel a uma camiseta nos fica claro que existem inúmeras diferenciações entre os dois, apesar de ambos serem frutos da produção industrial. O estudo que pretendemos realizar está relacionado à compreensão do vínculo entre os grupos sociais e os bens de consumo. Julgamos que essa associação se estende para além do objeto em si, pois as relações sociais acrescidas pela manipulação midiática e que terminam por definir a percepção que as pessoas têm de algo ou alguma coisa, se faz essencial para refletirmos acerca dos objetos que nos cercam.

As conexões que podemos estabelecer entre objetos, isto é, entre eles mesmos, deve contemplar, entre outras coisas, quais deles possuem maior interação entre si, ou aqueles que são entendidos sob óticas similares por possuírem noções hegemônicas de interpretação parecidas. Essa categorização pode ser feita a partir da análise de uso, da forma de produção, dos valores simbólicos distintos, da região em que foram concebidos e muitos outros aspectos que formam pontos de contato entre eles. Entretanto são as relações humanas com os bens de consumo que de fato vão evidenciar o valor de uso e o valor de troca simbólica de cada um deles, dando margem assim à criação de elementos que possibilitem associações entre sua produção, circulação e consumo.

Essa pesquisa apresentará uma análise de alguns pontos condutores para se debater concordâncias e divergências entre categorias de objetos que têm como intercessão a noção de que seu desenvolvimento se dá a partir disso que se nomeia como produção criativa, que difere da produção dos outros objetos industriais e que de modo geral julgamos não serem criativos. Compreendemos que a produção criativa abrange diversas esferas da indústria, incluindo isso que se chama de indústria cultural, tal como a música, o teatro e o cinema, porém o que vamos 
abordar dentro da noção de produção criativa são objetos de arte, objetos de artesanato e objetos de design.

Ao longo do trabalho sustentaremos a divisão entre campos, tal como a teoria social de Pierre Bourdieu definiu o campo e que por vezes essas fronteiras podem nos parecer uma separação um tanto ou quanto nebulosa. Mas sustentamos que a partir de uma argumentação pautada nas Ciências Sociais é possível debater certos padrões baseados no exame das estruturas sociais e julgamos que é possível uma demarcação de fronteiras mais precisa ou clara, entretanto sabemos que é inegável a existência de uma flexibilidade quanto a esse tipo de classificação.

A motivação para contemplarmos justamente esse grupo de objetos especiais, digamos assim, se dá por diferentes fatores, porém, o principal deles é pela aproximação simbólica de seus produtores. Eles são nomeados comumente como pessoas criativas (artistas, designers e artesãos) e, desse modo, como desenvolvedores de produtos com forte apelo estético ou com uma preocupação maior em produzir algo que seja minimamente dirigido à contemplação ou à fruição estética.

O objetivo desse debate é investigar como se dá a prática profissional do artista, do designer e do artesão e quais relações podemos estabelecer entre os produtos ou mercadorias que são produzidos por cada um desses profissionais, seus campos de atuação e a sociedade capitalista. Ademais, nos parece fundamental para a compreensão das conexões entre esses profissionais com o público consumidor dessas categorias de objetos que possamos desmistificar algumas crenças estabelecidas como verdades inquestionáveis em relação ao que de fato se entende por produção criativa, e como esse tipo de trabalho opera dentro da lógica do mercado capitalista vigente nos dias de hoje.

Procuramos evitar os estudos realizados através das críticas do juízo do gosto ou da oposição puramente entre as características funcionais e as estéticas. Empregando as Ciências Sociais pretendemos realizar uma análise de como as relações humanas fundadas nas relações de trabalho estabelecem determinadas classificações para os produtos ou mercadorias de um modo geral, portanto teremos como ponto norteador de nossa investigação o contexto social onde as mercadorias ou os bens de consumo estão inseridos. Do mesmo modo, 
consideramos primordial que se entenda primeiro qual o perfil ${ }^{2}$ do profissional que desempenha sua prática profissional no Campo da Arte, do design e do artesanato, daí então partiremos para definir quais são suas similaridades e diferenças.

Essa pesquisa se iniciou a partir de um interesse pessoal em verificar a veracidade de alguns conceitos amplamente difundidos entre os pares do Campo do Design, principalmente dentro da universidade, quando essa pesquisadora ainda era graduanda em design entre os anos de 2009 e 2013 na PUC-Rio. Nos parecia haver uma difusão sistemática dentro do campo, de uma noção romântica e passadista acerca da criatividade vinculada primordialmente ao Campo da Arte, mas que acabou por ser adotada por outras áreas, como a área do design. Pudemos perceber que a perpetuação dessas crenças acabava por abrir grandes lacunas entre o ensino universitário do design e a real atuação dos profissionais dessa categoria no mercado de trabalho de um modo geral, o que tinha reflexo também em uma dificuldade clara para mim e para meus colegas de graduação em design saber definir o que era realmente a natureza da sua profissão. Desta forma, uma parte desse trabalho exercerá uma crítica a esse modo de ensino, que nos parece ser adotado em praticamente todas as escolas de design.

Nossa investigação acerca das fronteiras entre os campos considera que a noção da criatividade inata é um ponto intercessor entre o que se compreende sobre a atuação profissional do designer, do artesão e do artista. Em consequência disto, acreditamos que ocorrem certos equívocos teóricos difundidos ainda no ensino universitário, que tornam a separação destes trabalhos um tanto nebulosa. Assim, antes de adentrarmos em nossa pesquisa, vale considerar que não desejamos estabelecer uma defesa intransigente em relação a separação total de áreas de atuação, ou que essa fronteira deveria ser engessada e não flexibilizada. Nossa defesa tem como objetivo esclarecer a origem de algumas crenças, como ocorreu esse deslocamento e como se deu a sua perpetuação para o Campo do Design, assim como qual a interferência desses mitos nas fronteiras que separam o aluno de design do mercado profissional que ele encontra fora da universidade.

Paralelamente ao objetivo principal dessa pesquisa, quando nos

\footnotetext{
${ }^{2}$ Quando tratamos de perfil do profissional estamos nos referindo a visão social constituída acerca dele e também a como se dá geralmente a sua formação na sua área específica de atuação e sua atuação no mercado de trabalho.
} 
esforçávamos para definir com maior clareza a fronteira entre a arte e o design, começamos a estabelecer analogias com a produção e o simbolismo do trabalho artesanal. A homologia entre o trabalho do artista e do designer, parecia associarse integralmente ao trabalho do artesão, portanto, esses estudos - a aproximação da arte e o design do artesanato - se iniciara por conta de inúmeras viagens ao Nordeste do Brasil e da observação de diversos artesãos no estado de Pernambuco entre os anos de 2014 a 2017. Foi a partir dessa viagem que começamos a perceber certas semelhanças com o que vínhamos analisado em nossa pesquisa teórica (de mestrado) realizada na universidade, ou seja, verificamos que havia uma transposição da crença romântica da figura do artista para um campo associado, mas que não era necessariamente considerado como um verdadeiro ${ }^{3}$ Campo da Arte, isto é, naquela ocasião, pensávamos na eventual existência de um Campo do Artesanato $^{4}$, isto é, pensávamos que seria possível um dia provarmos que se tratava de um campo específico e que se verificava distinto do Campo da Arte, embora operasse com os mesmos pressupostos teóricos. Desse modo o debate das interseções e diferenças entre as produções dos objetos de artesanato, design e arte, bem como o entendimento ou significação social sobre quem seria cada um desses profissionais, emergiu como parte de nosso objeto de estudo.

Pretendemos compreender quais são os pontos de conexão e atrito que operam de forma muitas vezes imperceptível a um olhar desatento, ou mesmo para os atuantes das áreas, que com frequência se enxergam nesse limiar e se utilizam de subcategorias classificatórias para se definir. Por exemplo: categorias como artista gráfico, designer artístico ou designer artesanal, nos interessa entender se existe de fato a diferenciação entre estes profissionais e se eles se posicionam realmente na fronteira de duas categorias de trabalho.

De modo panorâmico podemos considerar que as noções que os pares

\footnotetext{
${ }^{3}$ De acordo com Pierre Bourdieu (BOURDIEU, P. A Distinção: Crítica social do julgamento. $2^{\mathrm{a}}$ Edição. Porto Alegre: Editora Zouk, 2006), a arte legitimada como verdadeira, assim como aquela que é consagrada como falsa têm como critério de discussão noções eruditas que se contrapõem na arena do Campo da Arte. Os agentes ou pares dominantes defendem isso que é a expressão erudita, já os pretendentes defendem outras formas de não institucionalizadas que geralmente chamamos de populares. $\mathrm{O}$ artesanato não seria, portanto, propriamente um campo, mas um subcampo do Campo da Arte.

${ }^{4}$ Optamos por tratar por Campo do Artesanato por julgarmos que atualmente a produção e venda de artesanatos opera de modo muito distinto da concepção da arte erudita, diferentemente de como a teoria de Pierre Bourdieu julgava a arte popular ou arte média, tal como a fotografia, como pertencente ao Campo da Arte (BOURDIEU, P. A Distinção: Crítica social do julgamento. $2^{\mathrm{a}}$ Edição. Porto Alegre: Editora Zouk, 2006).
} 
empregam para definir um objeto como arte ou como design, são, na verdade, desdobramentos de uma mesma prática profissional que outrora chamávamos de artesanato. Logo, assim como todas as outras práticas laborais, elas eram compreendidas como ofício desde a Antiguidade Clássica e isso foi válido praticamente até o final do Antigo Regime. Conforme foram ocorrendo as mudanças sociais, aconteceram também seus desdobramentos para áreas mais específicas e impossíveis de se conceber ou compreender dentro da estrutura social da Idade Antiga. Assim, a pintura e a escultura, por exemplo, que eram meras práticas artesanais, passaram a ser outra coisa, passaram a possuir outro significado, passaram a ser compreendidas de outro modo. E para efeito de aplicação, gostaríamos de considerar aqui o final da Idade Média com o golpe de misericórdia à metafísica católica realizado por Kant. ${ }^{5}$ Hoje, e mais uma vez, todas essas práticas laborais, curiosamente dividem espaço com o artesanato. De forma simplificada, poderíamos considerar o artesanato como um ponto de intercessão entre o design e a arte, uma vez que ambos são fruto do desdobramento histórico que o artesanato sofreu. Ademais, nos dias de hoje o artesanato pode possuir tanto um valor decorativo, tal qual a arte, como valor utilitário, tal qual o design industrial. Em outras palavras, o artesanato brasileiro atualmente se propõe a desenvolver peças únicas e puramente contemplativas, como também peças seriadas manufaturadas ou semi-industriais, que podem ser funcionais ou decorativas.

Tal como indicamos mais acima, a outra relação que se estabelece entre esses objetos especiais ou criativos é a sua condição como mercadoria, condição essa que cada um desses profissionais admite ter, ou simplesmente a omite, afirmando a sua gratuidade. ${ }^{6}$ Para o artesão esse objeto expressa ou traduz a produção ou um trabalho que serve como meio de subsistência. Com veremos adiante, verificamos que os artesãos não têm pudor de dizê-lo abertamente e em

5 Quando Kant escreveu a Crítica da Razão Pura (KANT, I. Crítica da Razão Pura. Tradução:

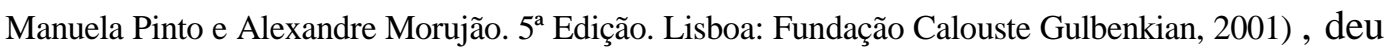
o golpe de misericórdia na metafísica cristã, afirmando que seus pressupostos não poderiam ser mais sustentados com os argumentos irracionais, tal como explicavam os milagres e a fé. A partir de agora, a explicação das coisas que não eram explicadas pela razão, tal como a beleza, teria uma ciência própria, a estética. ${ }^{6}$ Pierre Bourdieu menciona em a Produção da Crença, que os colecionadores de arte adquirem suas peças não para o comércio, tal como manda o modo de produção capitalista, mas por "amor à arte" (2005). 
muitos casos adéquam especificidades do produto conforme a demanda do público, admitindo uma produção voltada para o consumo. ${ }^{7}$ Já para o artista essas relações de compra e venda se mostram mais veladas. Normalmente justificando que a sua produção se dá primordialmente por razões pessoais ou sentimentais, razões essas posteriores e mais relevantes do que a intenção de comércio. E por fim o designer, cuja posição normalmente se assemelha às anteriores. Assume que se localiza dentro da estrutura capitalista e que sua atuação se dá principalmente na produção industrial. Contudo, essa consciência é confusa, pois geralmente se vê na figura do artista. Escamoteia o fato de que sua prática profissional se dá na produção ou manufatura de objetos de design.

Nessa introdução, gostaríamos de deixar claro que nossa reflexão se sustenta apenas em linhas gerais dos fenômenos observados e, portanto, nossos escritos possuem um caráter ensaístico, afinal julgamos que não estamos tratando de uma ciência exata, e gostaríamos de lembrar que as exceções estarão presentes em todas as comparações e debates listados acima. Ao longo de nossa pesquisa essas analogias e divisões serão debatidas com intuito de se estabelecer paralelos entre o que compreendemos hoje hegemonicamente acerca de cada profissional de forma isolada, e comparativamente com os demais que pretendemos analisar. Utilizaremos uma argumentação pautada em dados históricos e no contexto social, daí o trabalho desses profissionais, e as suas relações sociais, serão examinadas também sob o ponto de vista político e econômico.

Para trazermos essa investigação ao âmbito brasileiro, realizamos uma pesquisa empírica com artesãos, designers e artistas da região nordeste. Sustentamos que essa região, possui uma rica produção artesanal e passível de uma análise na qual transparece em absoluto a relação da permanência dessa cultura "primitiva"8 com as necessidades sociais e econômicas que muitas vezes não são possibilitadas por políticas públicas equivocadas do Estado.

E, como uma espécie de contraponto, ou tal como nas teclas dos pianos, as

\footnotetext{
${ }^{7}$ Gostaríamos de lembrar que consideramos aqui a fala dos artesãos que tivemos ocasião de conversar no Nordeste brasileiro, daí é preciso ter em mente que o que disseram, esse despudor em relação aos objetos que fabricam e que dizem ser para o consumo, foi observado apenas naquela região do país. Intuitivamente, julgamos que o mesmo ocorre em todo o país, mas essa verificação não foi comprovada.

${ }^{8}$ Utilizamos aqui o termo "primitivo" por ser empregado por Néstor García Canclini (CANCLINI 1982: 17), autor que temos como referência nesta dissertação. Porém, gostaríamos de esclarecer que consideramos o emprego deste termo como uma visão taxativa oriunda de um observador ocidental moderno e urbano. Julgamos que "sociedades não complexas" seria mais adequado para se tratar destas comunidades produtoras de artesanato.
} 
consoantes e as dissonantes, optamos por examinar a questão do design dentro da mesma região. Entrevistamos os artistas e os designers que se firmam e operam em capitais, onde a lógica da estrutura social é muito diferente do interior rural, inclusive pelo acesso à educação em nível superior dentro da área de atuação específica. Enfim, o que nos coube foi relatar diálogos registrados em campo de forma empírica, entre o que se compreende pela figura do artista, do designer e do artesão. A forma como se definem os objetos produzidos por esses profissionais e como se incorporam à sociedade. Pelo exame dos dados obtidos desse microcosmo, sustentamos, mas não sem certa apreensão por estarmos enunciando considerações equivocadas, podemos inserir essa investigação dentro do território nacional como um todo e utilizando como recorte o nordeste brasileiro.

Dessa maneira, julgamos que poderemos construir nossa análise acerca da separação ou fronteira entre os campos teoricamente, mas mantendo uma argumentação baseada também no exercício das atividades que serão postas em exame e que se dão na prática. Sustentamos essa estratégia teórica pois verificamos que há razões para que haja tal justaposição entre esses campos, tanto no estudo universitário, quanto no que se pode examinar no mercado de trabalho e nas considerações ideológicas de um modo geral.

A nossa pesquisa se apresenta da seguinte forma: no primeiro capítulo intitulado por As Crenças e Fundamentos das Práticas Criativas, nos ocuparemos disso que é compreendido como trabalho criativo hegemonicamente, e apresentaremos dados históricos a fim de comprovar quando e em que contexto essa noção surgiu. Em linhas gerais a investigação se sustentará na percepção de que isso que se entende por criatividade está diretamente vinculado à figura do artista e desse modo a uma autonomia pessoal, a uma individualidade produtiva, considerando o que passou a se entender por artista após o século XIX. A dita autonomia ou independência do artista, percebida como complementar a isso que se define como prática criativa, será amplamente questionada ao longo do texto, assim como o porquê de atribuirmos essa noção aos profissionais que estamos nos referindo na investigação, isto é, ao designer, ao artista e ao artesão. Discutiremos como o entendimento de criatividade perpassa por toda a formação ideológica da figura desses profissionais e porque essa "característica" acaba por distingui-los socialmente dos outros trabalhadores. Para essa análise e debate, utilizaremos como base principalmente as teorias sociais de Pierre Bourdieu e suas 
considerações sobre a distinção social. Importa ressaltar que a teoria social de Pierre Bourdieu, muitas vezes será apresentada de modo difuso, sem as referências bibliográficas de praxe, mas consideramos que nossos leitores, ou qualquer leitor familiarizado com as Ciências Sociais, perceberá a mão desse autor.

O ponto central deste capítulo será o questionamento acerca dessa noção a genialidade do criador -, que para nós tem uma veracidade mítica, ou seja, que está sedimentada no imaginário social e é hegemônica, mas que a sustentaremos como absolutamente fictícia. Discutiremos a conjunção direta que existe entre a criatividade, a arte e o design e como esses três termos ou conceitos se inserem em contextos extremamente distantes da prática artística, servindo apenas como adjetivo para se categorizar pessoas ou coisas como superiores aos demais. Isto é, entendemos que o projeto de uma cadeira de design, o futebol arte ou uma propaganda comercial criativa como coisas dotadas de uma natureza especial, excepcionais às outras da mesma categoria e desse modo trataremos da distinção de status social que esses conceitos carregam e qual a distância entre a noção mítica designada pela adjetivação dos nomes desses trabalhos e a prática concreta deles atualmente.

No primeiro subcapítulo, O Conceito de Criatividade no Design e na Arte, debateremos as questões referentes a compreensão do que é criatividade e como essa noção se desdobra dentro desses três campos, apresentando a singularidade de cada um. Sustentaremos que conceito de criatividade dentro do design e do artesanato foram herdados do Campo da Arte e são datados do período do Romantismo na Europa, isto é, em uma época que a noção de arte já estava dissociada do artesanato. Entretanto atualmente podemos compreender o artesanato como algo criativo e como uma vertente da arte em geral, ocorrendo assim uma inversão de hierarquia de legitimação, colocando a arte como um campo autônomo e distinto, cujas noções passam a ser exportadas para outros campos. Apresentaremos uma discussão argumentativa com intuito de esclarecer nosso posicionamento na defesa de que toda arte é manufatura ou uma forma de trabalho e que toda forma de trabalho é potencialmente criativa, utilizando como suporte o livro de Janet Wolff, A Produção Social da Arte, estabelecendo assim a noção contemporânea de criatividade como algo arbitrário e construído, como fruto de treinamento e não mais como uma característica inata de alguém dotado de uma natureza especial. 
Ainda utilizando A Produção Social da Arte como referencial teórico, manifestaremos nossa posição no segundo subcapítulo intitulado de $O$ Trabalho Coletivo e as Expressões Individuais do Criador Moderno, acerca do que se entende por autonomia produtiva, apontando tal crença como irreal e passadista, fruto da noção romântica da arte, tal como a noção de criatividade. Defenderemos o trabalho como prática coletiva sob qualquer circunstância, afinal somos seres sociais e não vivemos isolados de todo e qualquer contato com outras pessoas, ou de coisas fabricadas por outras pessoas. E, assim como a criatividade, a autonomia ou individualidade está conectada intrinsecamente à figura do artista, que é tido como detentor de todo processo de trabalho, ou seja, entende-se que quando se pinta um quadro, por exemplo, todo o trabalho se dá de forma individual, uma vez que o artista exprime um sentimento pessoal e tem o domínio de toda a manufatura que é desenvolvida de forma isolada. Analisaremos o quão julgamos ser equivocada essa crença, e de que modo o trabalho coletivo está presente na produção artística, uma vez que não podemos perceber a individualidade do trabalho apenas no ato da pintura, afinal para que isso se dê e depois se comercialize existe uma grande rede de pessoas nesse processo.

Seguindo dentro da temática da individualidade, analisaremos o discurso artístico sobre a expressão unicamente sensível, difundido como motivador da prática artística, isto é, questionaremos a crença na arte como uma manifestação pessoal pura e simplesmente, sob o argumento de que somos fruto da estrutura social e que nela estamos inseridos, desse modo a arte também se relaciona com o contexto social e histórico vigente no momento da concepção, logo julgar a arte como uma expressão unicamente subjetiva é novamente formular reflexões superficiais, na qual a análise não se estende para além do objeto e do artista, ou seja, não contempla a sociedade como um todo.

Como subcapítulo de encerramento, denominado de A Cultura Erudita e a Cultura Popular - Uma Visão a Partir das Definições de Canclini, refletiremos e debateremos com base no autor (Néstor García Canclini), o que é isso que tratamos por cultura. Afinal, utilizamos essa palavra massivamente no nosso cotidiano, porém dificilmente nos perguntamos o que cultura de fato significa, uma vez que já está tão enraizada no nosso vocabulário a empregamos sem buscarmos refletir previamente sobre seus conceitos primordiais. Por exemplo, quando utilizamos a palavra cultura como adjetivo, e dessa forma a utilizamos 
coloquialmente para caracterizar as pessoas como cultas, estamos também imprimindo sobre essas pessoas um privilégio ou uma distinção social, uma vez que compreendemos por culto aquele que é letrado, que domina saberes eruditos, tal como filosofia, literatura ou artes. Entretanto a cultura popular traz e transporta paradigmas diferentes, ela nos remete muito mais a um saber assistemático, a expressão de comunidades a partir das crenças e ritos. Aprofundaremos essa reflexão, aqui superficial, de forma mais ampla no texto, criando paralelos entre a pesquisa de objetos, a fim de compreender aonde as áreas de atuação do design, da arte e do artesanato se encontram dentro das noções de cultura e cultura popular. Compreender essa definição nos será útil também para sustentarmos o debate sobre a diferenciação social das práticas, ou a luta de classes, ou se desejarmos dos lugares sociais, que ficam explícitas dentro da valorização maior ou menor de cada categoria de objetos, e quais as diferenças sociais fundamentais entre os produtores de cada uma delas. Desse modo compreender o significado do termo cultura, nos abrirá espaço para questionarmos o status social presente na arte e no design, e a visão taxativa e elitista ocidental moderna, que empregamos em relação ao artesanato, uma vez que é claro que existe uma hierarquização entre a cultura erudita e a cultura popular.

O segundo capítulo intitulado como As Relações Fronteiriças na Produção de Objetos - o Design, a Arte e o Artesanato como Elementos de Comparação, adentrará de modo mais preciso ao questionamento acerca das correspondências e diferenciações em relação às categorias de objetos que estamos estudando. Utilizaremos as noções debatidas no capítulo anterior, referentes às crenças hegemônicas sobre os artistas, os artesãos e os designers, que evidenciam como essas práticas de trabalho se dão, enfim, qual as lacunas estabelecidas entre o que se entende por esses trabalhos e como eles ocorrem de fato. Desse modo no segundo capítulo poderemos estabelecer relações mais claras entre as diferenciações do que se entende pela prática criativa, como ela se dá e finalmente qual o real reflexo desse trabalho nos objetos fabricados. Isto é, analisaremos se a noção romantizada do produtor pode ser sustentada quando nos atemos a tratar do objeto em si, sua forma de fabricação e como o mercado absorve esses bens de consumo, pois visamos discutir as diferenças simbólicas entre cada categoria de objeto, como o deslocamento espacial é capaz de produzir uma ressignificação dos 
produtos, e como agem os agentes legitimadores que consagram determinados bens. Ingressaremos no debate acerca da legitimação a partir de Bourdieu, o que nos dá margem para questionar se a aproximação das fronteiras dos campos se dá de forma diferenciada quando existe uma valorização maior ou menor de determinado objeto. Ou seja, o objeto quando legitimado tende a ser compreendido como possuidor de uma aura distinta, aproximando-se da noção empregada às obras de arte, e assim investigaremos se os objetos de design tidos como carismáticos, ou os artesanatos mais reconhecidos pelo mercado, possuem uma aproximação maior com o Campo da Arte que os demais.

Debateremos como operam os agentes legitimadores, a fim de questionar a natureza das escolhas por determinados produtos, isto é, se essa decisão é de caráter subjetivo ou mercadológico. Outro ponto que investigaremos são os locais destinados a exposição e venda de cada categoria de produto, quais as principais diferenças destes espaços e qual o perfil do público consumidor de cada um, evidentemente considerando as diferenciações das classes sociais tanto dos produtores quanto dos consumidores. Será destinado neste capítulo uma consideração mais centralizada a respeito da produção artesanal interiorana e da produção artística e industrial dos centros urbanos do nordeste brasileiro, incluindo assim uma pesquisa empírica e entrevistas realizadas na região.

O primeiro subcapítulo intitulado de As Intercessões e Dissemelhanças Simbólicas dos Objetos Industriais, das Peças de Artesanato e das Obras de Arte, proporá uma reflexão e debate acerca das diferenciações das práticas analisando primordialmente as palavras utilizadas para se referir a cada família de objetos, ou seja, como através da linguagem já podemos ter uma noção da hierarquia simbólica entre as famílias de objetos, isto é, o que se mostra mais imponente enquanto palavra, obra, peça ou objeto. Consideraremos também questões relacionadas à forma, à função e à construção do juízo de valor estético como algo inculcado e não de natureza subjetiva, o que nos dá margem para compreender também a oposição entre Arte Livre e Arte Aplicada. Esta primeira parte do capítulo se deterá na investigação do objeto enquanto produto e como se dão as relações de fabricação e consumo, considerando a estrutura social que estamos inseridos hoje, isto é, traçando paralelos com outras áreas do saber e não apenas sob visão do objeto em si e suas considerações sobre especificidades técnicas e estéticas, mas em uma busca para compreendermos simbolicamente como ele é 
inserido, produzido e consumido pela sociedade.

O segundo subcapítulo, A Produção Interiorana do Artesanato e as Feiras Regionais, se deterá em apresentar uma experiência empírica de investigação da produção artesanal interiorana nordestina realizada em 2017 nos estados de Pernambuco e Alagoas, traçando um paralelo com a pesquisa de Canclini acerca da produção artesanal na América Latina. Realizaremos uma análise social, política e econômica da região investigada, que será de extrema importância para a compreensão da simbologia do artesanato, uma vez que ele se dá no Brasil mais como forma de subsistência do que como prática criativa. Para isso mencionaremos não apenas as questões relativas a produção, mas também como e aonde essas peças são comercializadas, e como se dá a ressignificação do objeto quando ele sai do seu contexto territorial original.

Como último subcapítulo, Comunicação Visual e Artes Gráficas - Uma Visão das Práticas Pelos Profissionais Atuantes, apresentaremos entrevistas realizadas com profissionais do Campo da Arte e do Design coletadas em RecifePE e João Pessoa-PB, com intuito de avaliar de forma prática como os profissionais dessas áreas se veem localizados a partir das fronteiras imaginárias que estamos propondo. Desse modo, exporemos a interlocução na íntegra, seguido de uma análise teórica a respeito do material coletado.

A pesquisa se encerrará em uma longa conclusão na qual analisaremos de forma geral tudo que foi debatido traçando pontos de congruência entre as problemáticas apresentadas e expondo com mais veemência nossa opinião pessoal a partir de nossas experiências empíricas, e desse modo, estabelecendo pontes entre aquilo que se entende como prática e aquilo que debatemos teoricamente. 


\section{As Crenças e Fundamentos das Práticas Criativas}

Principiamos este capítulo com o título de "As Crenças e Fundamentos das Práticas Criativas" sustentando que a maior parte daquilo que é identificado pelos pares do Campo do Design como prática criativa infelizmente é tratado teoricamente de forma superficial e de maneira hegemônica sem a presença do contraditório, ademais possui uma ligação ou uma aproximação com a noção de prática criativa tal como ela é entendida no Campo da Arte, sejam as artes plásticas, literárias, musicais ou qualquer outra área próxima compreendida por esse título. Constatamos com curiosidade que o uso da palavra arte geralmente é acompanhado da noção de criatividade e autonomia ou expressão individual do criador.

A noção de arte associada à noção de criatividade é de tal ordem que até entre aqueles que gostam e discutem o sobre futebol, por exemplo, uma das inequívocas paixões nacionais, é de comum acordo que existe a noção de um futebol arte que é muito diferente do outro tipo de futebol, ainda que ele nunca seja nomeado como tal, mas para quem discute futebol, todo mundo "sabe" exatamente que existe um "futebol arte" e o futebol de "outro tipo". E mais ainda, "sabem" que determinados jogadores atuam de forma criativa em campo, enquanto a maioria apenas joga futebol do "outro tipo".

De fato, os termos arte e criatividade são empregados como adjetivos qualificativos para quase todas as práticas humanas e utilizados para reafirmar o talento ou dom de alguns, sejam de marceneiros, dançarinos, cozinheiros, costureiros ou de jogadores de futebol que passaram previamente por um processo de legitimação entre seus próprios pares dentro do Campo do Futebol, se é que podemos afirmar que exista um Campo do Futebol. ${ }^{9}$ De qualquer modo é fato que podemos afirmar que existe uma verdadeira "indústria"10 do esporte, isto é, um regime de funcionamento particular de operação, um modo específico ou singular

\footnotetext{
${ }^{9}$ Evidentemente que não estamos nos referindo ao lugar onde se joga o futebol, mas à noção de "campo" formulada por Pierre Bourdieu.

${ }^{10}$ Pensamos o termo indústria como conjunto de práticas e trocas econômicas que têm por fim a manipulação e exploração de matérias-primas e fontes energéticas, bem como a transformação de produtos semiacabados em bens de produção ou de consumo.
} 
de como as coisas funcionam ou acontecem no âmbito do futebol, a maneira como os pares do eventual Campo do Futebol se comportam, a forma como eles constroem seus heróis e seus próprios valores, que produzem uma certa amálgama que reúne o todo dessa prática, como, por exemplo, normalmente os jogadores criativos são considerados superiores aos outros jogadores que jogam o futebol do "outro tipo". Consequentemente, caso desconsideremos que existam méritos reais ${ }^{11}$ desse ou daquele jogador, mas que exista apenas a sua valorização simbólica, esse fato tem reflexo financeiro direto na carreira esportiva desse ou daquele jogador, tais como contratos com times de elite ou uso da imagem pela indústria através do marketing, mesmo que ele seja apenas um jogador "normal", digamos assim.

Abrimos este capítulo com o exemplo dos jogadores de futebol, mas não aprofundaremos este debate para além desse ponto. O que vale para nós aqui é evidenciar objetivamente como o uso das palavras arte e criatividade são recorrentes em nossa cultura, e das diversas noções ou sentidos que a mesma carrega e que empregamos de modo equivocado na grande maioria das vezes, onde raramente é questionado isso que é arte e o porque Pelé e Garrincha, por exemplo, serão sempre lembrados como "gênios" do futebol arte, seja lá o que isso possa significar. Portanto, o que gostaríamos de saber é como é que as pessoas que gostam de futebol sabem claramente qual é a diferença entre o que é futebol arte e o futebol de "outro tipo". Quem ensinou a elas aquilo que sabem sobre criação ou arte no âmbito do futebol? E como uma noção que pertence ao Campo da Arte, pode migrar para o Campo do Futebol? Afinal a noção de arte é anterior à do futebol.

Usar o exemplo do futebol, oferece como intento indicar que um dos inúmeros campos que frequentemente empregam a palavra arte, possui o mesmo sentido do que o empregamos no Campo do Design ou mesmo no Campo da Arte, sendo de grande importância também esclarecer que não estamos fazendo críticas diretas ao uso do termo em ambientes não pertencentes ao Campo artístico tradicional de forma coloquial, mas sim para frisar que para prosseguirmos com

${ }^{11}$ Consideramos que os méritos pessoais podem ser reais ou imaginados. Nesse caso estamos considerando que os méritos dos jogadores são mais imaginados do que efetivos, embora haja realmente jogadores que possuem habilidades que os outros não possuem. O "grande jogador" é sempre o goleador ou o artilheiro, ainda que sem a sua equipe ele não possa fazer nada no campo. Mas a forma como enxergamos, fazem com que o artilheiro seja visto como alguém especial, ou dotado de méritos acima dos outros jogadores. 
um embasamento teórico adequado, é preciso que entendamos com mais clareza os fatores históricos e sociais que se relacionam diretamente com o conceito ou noção de arte, de criatividade, de autonomia do meio social e de cultura. ${ }^{12}$

É de comum acordo social, isto é, o senso comum ou o imaginário social, afirma que aquele que faz "arte" é "artista", entretanto não compreendemos com clareza quais são as atribuições reais desses termos quando utilizamos estas duas palavras para nos referirmos a objetos e pessoas. Nos dias de hoje é muito nebuloso dizer o que é um objeto de arte e finalmente quem é verdadeiramente um artista. Para além do uso cotidiano da palavra, quando a inserimos em uma discussão teórica, o rigor com os aspectos sociais e históricos dos termos devem ser levados em consideração. Arte é mais que um substantivo feminino empregado na definição prestigiada de alguns objetos da cultura material, ela é uma noção carregada de significados intrínsecos. Por exemplo, o entendimento por criatividade é massivamente atribuído a figura do artista, bem como a autonomia individual do seu trabalho e a produção de coisas da cultura como resultado.

Defendemos a noção real da figura do artista como um trabalhador e não a sua arrogante idealização. Do mesmo modo sustentaremos que os mecanismos de funcionamento das práticas criativas se relacionam com o mundo socialmente. Tendemos hegemonicamente a não considerar a arte como o resultado de operações de um mercado de trocas financeiras, apesar de existirem os leilões milionários de obras, o trabalho dos marchands, as vendas das galerias, as bienais que movimentam não apenas o mercado direto ${ }^{13}$ da arte como também o do entretenimento, isto é, as feiras anuais de arte como a da Basiléia (Art Basel) e inúmeros outros eventos e profissionais que promovem e alimentam o mercado financeiro de arte, e que mesmo assim, com toda essa manipulação ou especulação comercial que não tem nada a ver com a natureza estética das obras, nós (o público) continuamos considerando que a arte é um ato legítimo de expressão individual ou

\footnotetext{
${ }^{12}$ Entendemos cultura aqui, tal qual emprega Néstor García Canclini (CANCLINI 2005: 36), como o termo usado popularmente para definir aquilo que se acredita como arte maior, ou seja, o produto artístico identificado como dentro de um padrão de gosto de pessoas compreendidas como "cultas"

${ }^{13}$ Quando falamos em mercado direto, estamos apontando o mercado de compra e venda direta, isto é, quando a comercialização da obra de arte é feita diretamente com o artista, marchand ou em um leilão de obras de arte. $\mathrm{O}$ que se diferencia de uma feira de artes por exemplo, onde a maioria do público está interessado apenas na apreciação da obra, é também um evento de entretenimento, porém existe também compra e venda de objetos.
} 
autônoma do artista, que somente ele decide o que vai fazer e que ninguém mais no mundo intervém em sua produção.

Sarah Thorton em seu livro Sete Dias no Mundo da Arte afirmava que "as grandes obras não surgem simplesmente do nada; elas são feitas - não apenas pelos artistas e seus assistentes, mas também pelos marchands, curadores, críticos e colecionadores que 'apoiam' a obra" (THORTON, 2008: 15). Ou seja, é necessário repensar a autonomia criativa do artista, bem como a noção de que a produção artística ocorre de forma individual e praticamente sem contato com a sociedade.

A autora também enuncia discussões sobre a crença na arte por um viés antropológico, isto é, como um valor cultural sedimentado por séculos de história, afirmando que a maioria das pessoas defende que nada é mais importante que a própria arte (a noção tradicional) e que tudo aquilo que está por detrás da noção de autonomia ou independência absoluta do artista é considerado como algo a se ignorar, a noção da arte como expressão tradicional da cultura deve prevalecer sobre todas as outras formas de interpretação. De nossa parte defendemos junto a Pierre Bourdieu a noção teórica de um Campo da Arte, onde possuímos três agentes sociais e eles atuam conjuntamente, ainda que estejam sempre em disputa pela hegemonia no campo. Os agentes da produção (os artistas), os agentes de recepção (o público) e os agentes de circulação (os críticos, os museus e outras instituições de legitimação).

Aliás, outro equívoco que é preciso esclarecer é a manutenção da noção passadista do entendimento do artista como um profissional liberal e que trabalha individualmente vendendo livremente no mercado financeiro de arte a sua força de trabalho. Essa noção ingênua ignora as condições históricas concretas do modo de produção capitalista na qual os donos do capital são os donos de toda produção cultural, seja ela no âmbito da indústria ou disso que nomeamos (a elites nomeiam) como arte. Argumentaremos em favor de que todo tipo de trabalho é coletivo, mesmo este camuflado na figura do artista individual, que também carrega outras noções referentes ao seu próprio ser individual, como o do indivíduo marginalizado, isolado socialmente, boêmio, inconstante e genial. Apesar desta personificação da figura do artista ser compreendida hegemonicamente desta forma, essa noção foi constituída socialmente desde o início da Idade Moderna, e 
por ser uma visão romântica ${ }^{14}$ cabe a nós desmistificar esse conceito, bem como a noção de dom e criatividade como características espirituais enviadas por Deus a homens e mulheres escolhidos.

Ao analisarmos o Campo da Arte, o trabalho e a figura do artista, é preciso também que apontemos como isto é compreendido dentro da estrutura social em que vivemos e de que forma todas essas noções estão interligadas diretamente a noção de cultura. Afinal, o que é isso que compreendemos como cultura e que trata de diversas esferas sociais ligadas a arte, sua produção, distribuição e consumo? Pois assim como a palavra artista torna-se adjetivável, o atributo de culto também cumpre este papel, de forma que as duas características têm relações diretas quando vinculadas a indivíduos, que em geral socialmente ocupam um mesmo status perante a sociedade, aquele entendido como artista ou como culto estão em uma posição de diferenciação social perante a trabalhadores comuns, fazem parte de uma mesma elite intelectual que mais adiante vamos analisar a partir de Pierre Bourdieu e Canclini, que nisto há também uma ligação direta com o nível ${ }^{15}$ de extração social e o nível escolar de cada indivíduo.

A noção romantizada da figura do artista como alguém distinto ou prestigiado socialmente, criativo e autônomo, é também empregada no Campo do Design, onde o profissional do campo ideologicamente é caracterizado de forma muito semelhante com essa idealização. Apesar de sua força de trabalho ser empregada de forma mais direta na sociedade industrial, ou seja, aonde o objeto de design é tratado como mercadoria de maneira mais transparente do que a obra de arte, que simbolicamente teria um sentido mais "puro" ou "contemplativo" em relação aos outros objetos da cultura material. Entretanto designers e artistas são compreendidos dentro da estrutura social como dotados de potencialidades criativas únicas e inexplicáveis, tem a ver com as demandas de mercado, ou com a sociedade industrial capitalista.

Por fim, concluímos esta introdução do capítulo sintetizando que adiante, a discussão que será sustentada é com base nas noções hegemônicas acerca disso que é arte, cultura e como se desenvolve o trabalho do artista. Temos a intenção de

\footnotetext{
${ }^{14}$ A noção é do início da Idade Moderna, mas foi durante o período do romantismo que ela se consolidou e se propagou planetariamente.

${ }^{15}$ Pierre Bourdieu preferiria empregar o termo "localização", mas embora estejamos empregando outro termo pensamos a partir de sua teoria sociológica (BOURDIEU, P. A Distinção: Crítica social do julgamento. $2^{\mathrm{a}}$ Edição. Porto Alegre: Editora Zouk, 2006).
} 
compreender este campo com o olhar teórico embasado em uma análise social e histórica e não mais como fomos inculcados a enxergar através da estrutura social que vigora hegemonicamente. E como essa noção foi herdada por outras áreas profissionais e instauradas como uma espécie de verdade inquestionável.

\section{1}

\section{O conceito de criatividade no design e na arte}

“A mistificação que existe em se isolar o trabalho artístico como algo diferente e habitualmente superior a todas as outras formas de trabalho só podem ser combatidas mostrando-se que todas as formas de trabalho são (potencialmente) do mesmo modo criativas e que o trabalho artístico, como outros trabalhos, perde sua qualidade como 'atividade livre, criativa' sob o capitalismo'. (WOLFF, 1981: 27)

Assim inauguramos este debate com base na afirmação de que toda forma de trabalho é potencialmente criativa, entretanto esta noção, assim como a própria forma de trabalhar, sofreram transformações em relação aos diferentes e característicos modos de produção dos períodos históricos da história da humanidade. Aqui nos deteremos apenas na dimensão teórica, na noção, na ideiaforça das origens míticas do trabalho criativo, característico da cultura prémoderna para a moderna, que nos parece ser basilar para o entendimento da prática profissional do designer e a figura do artista, ou de modo geral de qualquer profissional que possamos nomear de criador. Já na Idade Moderna, a prática profissional do artista, passou a ser vista como se esse profissional fosse alguém dotado de uma natureza especial, noção essa que se confunde com a antiga (prémoderna) associação que outrora se fazia com o trabalho do artista, quando ela e todas as outras formas de trabalho, por definição eram de origem divina, isto é, dependia da alma que Deus oferecia para cada um. Nessa época as pessoas acreditavam que não eram os homens e mulheres que escolhiam suas profissões, mas elas eram desígnios divinos. E, do mesmo modo, que o fenômeno da criação ocorria de maneira isolada, sem depender da estrutura social que o artista estivesse inserido, o que efetivamente nunca ocorreu. Esta mistificação do trabalho criativo 
dos artistas, como o único que poderíamos denominar de criador e de uma forma de trabalho isolada, que embora nunca tenha existido realmente na história da humanidade, surpreende pela sua permanência nos dias de hoje.

A partir de um exame panorâmico dessa ideia-força, de um dos fundamentos ou princípios teóricos do Campo do Design, que hoje são reproduzidas e ampliadas pelos pares, parece-nos claro que existe um esforço sistemático para reproduzir e ampliar essa noção. Mas por qual motivo os pares do campo pretendem defender o passado? Que no passado essa forma de pensar tenha existido é algo que podemos compreender e explicar, mas mantê-la contemporaneamente, durante os estertores do capitalismo industrial e da sua ideologia comercial, não deixa de ser curioso. Como explicar a permanência de uma noção que existe em torno do trabalho denominado criativo tal como ela era pensada e defendida no passado? Perguntamo-nos por qual motivo os pares do campo reproduzem a noção passadista de que o dom da criatividade é algo que nasce com a gente, uma predestinação e, que seja necessário que ele seja expresso na forma de arte, e aquele que o detêm é um gênio com traços bem definidos na sua personalidade. Defendemos que essa noção só pode ser contestada evidenciando que todas as formas de trabalho são criativas, e que todas elas, incluindo aí a maneira artística chamada de "livre" e "criativa", estão submetidas ao modo de produção da sociedade capitalista, e exercem suas funções tal como essa engrenagem exige, isto é, ser produto ou mercadoria de troca comercial que chamamos de mercado dentro dessa estrutura.

Do ponto de vista histórico, podemos apontar em que momento a noção do artista como gênio criativo dotado de um dom ou graça superior aos dos outros seres humanos surgiu e porque o criador é visto como estando fora da sociedade, como marginal, excêntrico. Esta noção é romântica, é a noção moderna do artista datada do final do século XVIII e início do século XIX, momento no qual houve a ascensão do individualismo juntamente ao desenvolvimento do capitalismo industrial, bem como a real desvinculação do artista de qualquer grupo ou classe social bem delineada e seu afastamento do mecenato das sociedades de corte.

Quando o regime de circulação e proteção do trabalho artístico do mecenato foi substituído pelo sistema do crítico-comerciante, deixou o artista em uma condição precária para trocar ou comercializar o resultado do seu trabalho no novo mercado de trocas financeiras inaugurado pelo capitalismo. Agora o artista 
precisava sair do seu ateliê para vender a sua força de trabalho em troca de dinheiro, mas não tinha tempo e tampouco o domínio dessa modalidade profissional - o comércio - daí foi obrigado a delegá-la ao "marchand de tableaux". Antes disso, ele vivia sob a proteção do mecenas como um serviçal da sociedade cortesã e a sua produção era consumida por esse grupo social, mas não havia remuneração na troca, apenas proteção patriarcal. Raramente o artista era remunerado em dinheiro ou salário, mas algumas vezes obtinha presentes eventualmente valiosos, como joias ou pequenas parcelas de terra. Podemos dizer que a evolução da sociedade industrial marginalizou o trabalho do artista e ao mesmo tempo ofereceu em troca uma efêmera distinção social, pois sua forma de trabalho passou a ser tida hegemonicamente como uma forma de trabalho "diferente" das outras, mas o artista não tinha nenhuma garantia de que o sucesso de suas vendas persistiria enquanto durasse a sua atividade profissional. Mesmo nos dias de hoje a noção de fama e sucesso na vida dos artistas, como sabemos, é precária, pois raros são os artistas de sucesso financeiro durante toda sua vida profissional.

Antes do Renascimento, na Europa, os artistas trabalhavam nas mesmas condições sociais de outros trabalhadores. Na verdade, a denominação "artista" não existia como nos dias de hoje e eles, de fato, eram esses trabalhadores, eram meros oficiais mecânicos, artesãos, músicos, atores etc., mas isso não quer dizer que os seus trabalhos eram de baixa qualidade técnica. Sistematicamente, seus conhecimentos e técnicas eram passados de geração para geração. Todos esses ofícios eram simbolicamente equivalentes e igualmente importantes, enfim, desempenhavam um papel social similar. Estes artesãos ou trabalhadores que operavam todas as práticas profissionais, assim como aqueles que hoje chamamos de criativas eram geridos pelas guildas, que eram corporações de ofício que as cidades possuíam e que administravam o trabalho, definiam a sua qualidade técnica, assim como postulavam os preços a serem cobrados, enfim, definiam as regras do trabalho de forma absoluta. $\mathrm{Na}$ tentativa de romper com as regras corporativas a nobreza e a igreja a fim de, por exemplo, trazer um pintor de outra cidade para ornar uma capela, criaram outro tipo de condição de trabalho, que a exemplo das academias literárias - local de encontro de membros da nobreza intelectualizados e com aspirações literárias - chamamos de Academia. As Academias passaram a ensinar institucionalmente (o que antes era feito de modo 
assistemático e prático nas famílias dos artesãos) pintura, música e literatura (poesia). Rapidamente as academias de arte se sobrepuseram às leis e regras das guildas para a gestão dos trabalhos, tendo agora suas próprias regras, mas com uma particularidade, os acadêmicos estavam livres das normas das guildas, isto é, os acadêmicos eram proprietários individuais do seu conhecimento e podiam vendê-lo livremente no mercado em qualquer cidade que resolvessem visitar. Os antigos artesãos, agora formados nas Academias, passaram a possuir uma distinção social em relação aos outros que não tiveram o privilégio desse estudo e inserção social, e aí surgem as divisões dentro disso que se nomeava artesanato e agora passa a ser chamado de arte. Verifica-se o surgimento das distinções nas classificações como arte "maior" (artista Acadêmico, aquele que havia frequentado uma academia de arte) e arte "menor" ou decorativa (artesanato). Portanto, a designação de maior ou menor, não é uma reposta a um problema técnico ou estético de um produto denominado criativo ou de arte, mas uma questão de natureza extra-estética, uma noção social arbitrada como se fosse um problema teórico da arte.

Entretanto na Idade Moderna, com o início do modo de produção mecanizado e da sociedade capitalista, cumpriu-se um dos maiores paradoxos da história da humanidade, o trabalho que antes produzia coesão social e propiciava sentido para todas as relações sociais, permitindo progresso e civilização dos homens e mulheres foi desumanizado. A prática laboral, qualquer que seja ela, obscurecida a sua natureza real e humanizadora, elemento que tornava a divisão entre as formas de trabalho e os valores humanos mais claras, isto é, onde o melhor artesão era também o homem mais respeitado socialmente, aquele que tinha o maior domínio técnico de sua "arte" seria o artesão mais digno e por essa razão o mais bem remunerado, deixou de existir. Daí os homens mais dignos, os mais respeitados exatamente por suas atividades profissionais, foram obscurecidos ou inferiorizados socialmente. Mais tarde, quando os artesãos saíram dos ateliês e foram para as usinas, quando não eram mais donos dos meios de produção, as relações hierárquicas estabelecidas dentro das fábricas, por exemplo, afastaram temporariamente ainda mais o operário do artesão (esse último, agora visto como artista), aquele que possuía o domínio de um trabalho autônomo e que poderia vendê-lo livremente e que agora se desvinculava do sistema de patrocínios facultado pela nobreza aos músicos, artesãos, escritores etc. 
Outro aspecto importante de contemplarmos é que nos parece que os pares do Campo da Arte dos dias de hoje também se esforçam em apagar ou silenciar. Esse aspecto diz respeito à noção social de artista na modernidade. Trata-se da questão da individualidade, que como vimos passou a vigorar de modo mais acentuado, com o fim da sociedade cortesã. Tendem ou se esforçam a nos convencer, a nos fazer crer que o trabalho artístico ou criativo é realizado de forma individual. Há um esforço para que acreditemos no artista trabalhando isolado no seu ateliê, alguém que expressa emoções próprias e foge dos moldes de produção da sociedade capitalista. Mais acima indicamos que esta noção era romântica e havia surgido no mesmo período histórico de modificação das formas de trabalho do "Ancien Régime", mas é preciso salientar que não existe trabalho que não seja coletivo, da mesma forma que até mesmo o artista moderno está subordinado às leis do mercado de trabalho da sociedade industrial, onde a sua obra é laicizada e se torna produto ou mercadoria que pode ser invertida em dinheiro. Que assim como qualquer outro tipo de trabalho a arte também é moldada pelas exigências deste mercado. Todas essas convenções sociais que foram inculcadas e que cremos hoje serem verdadeiras em relação a natureza libertadora do trabalho do artista, o verdadeiro trabalho criativo, podem ser desmistificadas quando analisadas historicamente e para compreender qualquer relação do chamado "trabalho artístico" com a sociedade é necessário abordarmos essas questões.

Apesar de termos os fatores históricos nos servindo como base para afirmarmos que a noção de artista tal qual temos hoje é uma idealização romântica, a maior parte das pessoas segue acreditando que o artista é um gênio isolado, incompreendido, uma espécie de personagem que é interpretado apenas pelos pares da classe artística. A noção da arte como expressão visceral necessária aos homens verdadeiramente livres permeia o imaginário social contemporâneo, e quando nos deparamos com um quadro de vanguarda por exemplo, queremos entender e sentir um pouco do que o artista sentiu, o que ele gostaria de dizer com suas incompreendidas pinceladas. A ideia de isolamento para a criação plena também é tida como verdade, o afastamento da sociedade como incentivador da criação, como se quanto mais distante socialmente fosse, mais fácil se conectar espiritualmente com o eu interior e daí se emanasse o dom, do ato intuitivo e pessoal, na verdade é uma falácia. Como podemos tomar isso como verdade se o 
artista faz parte de uma sociedade e precisa dela para desenvolver os seus trabalhos e posteriormente vendê-los? Afinal, não somos seres isolados e atualmente é impossível sê-lo, precisamos da estrutura social que fazemos parte, tanto para suprimento de funções básicas cotidianas como para a produção e circulação intelectual e cultural dos nossos trabalhos e de nós mesmos.

Ocorre que a história da arte, tal como ela é ensinada nas escolas, e dessa forma como ela reforçada e compreendida hegemonicamente de forma superficial, nos mostra que o artista, principalmente a partir do Modernismo, é visto de forma romantizada. Como essa noção pode ser sustentada? Defendemos que uma das razões para a romantização da figura do artista é que o mercado da arte transmite a crença de que o lucro é apenas uma consequência, pois quem consome a arte o faz "por amor"16 a ela, e não por questões financeiras.

A noção romântica da figura do artista além de minimizar a prática necessária para se tornar um artista de fato e para que ele possa viver da sua força de trabalho, também gera rótulos referentes ao pouco exercício profissional, a noção do sujeito social vagabundo, com muito tempo ocioso, que despende mais tempo fruindo do que de fato produzindo alguma obra. Essa crença no pouco trabalho do artista e a forma pejorativa com que isso é compreendido socialmente, é o segundo ponto na nossa defesa sobre a negatividade da noção romântica. As circunstâncias sociais atuais nos fazem crer em afirmativas éticas para a vida laboral tais como: "o trabalho dignifica o homem", "Deus ajuda, quem cedo madruga", "quem dorme sonha, quem trabalha conquista". Somos condicionados a acreditar que para se ter uma vida digna e moral é necessário que se trabalhe regularmente, oito horas por dia e cinco dias por semana, caso contrário se é um vagabundo, alguém que não é bem quisto socialmente. Podemos usar como exemplo o caso dos ciganos no cenário europeu, que até os dias de hoje sofrem perseguição social e política, muito porque também não estão dentro das convenções tradicionais do trabalho. Ou bem os índios na América Latina, não aceitos dentro de seus padrões originais de subsistência diretamente dependente da natureza, tanto na agricultura familiar subordinada a um ciclo do crescimento das plantas, quanto nas práticas extrativistas, função referente a alguns integrantes do povo e que não demanda de uma rotina como a que entendemos como ideal

16 BOURDIEU; Pierre. A Produção da Crença - Contribuição para uma Economia dos Bens Simbólicos. $3^{\text {a }}$ Edição. Porto Alegre: ZOUK 2005. 
dentro de um padrão ocidental moderno. Em suma, somos condicionados socialmente a entender o "trabalho" como uma forma específica e aceita de comportamento social. Uma noção pautada em uma legitimação de que o mérito pessoal do indivíduo está diretamente relacionado a isso que hoje compreendemos como trabalho. Mas será que de fato precisamos trabalhar por tantas horas semanais? Ou o trabalho que executamos é realmente útil a sociedade?

O antropólogo americano David Graenber em um pequeno e recente artigo para a revista Strike! Maganize, sustentava a noção de que aquilo que profetizou o economista John Maynard Keynes em 1930, que no final do século (século XX) teríamos um avanço tecnológico tamanho que um trabalhador poderia trabalhar em média 15 horas semanais devido a automatização dos trabalhos produtivos, o que de fato não ocorreu. Apesar de ter verdadeiramente havido a automatização e a diminuição do trabalho humano dentro da indústria e do campo (agricultura), foram criados outros trabalhos, como em setores de venda, que tiveram crescimento exponencial, além de trabalhos burocráticos e administrativos. Segundo o autor, a razão pela qual não se diminuiu a quantidade de horas trabalhadas devido ao avanço tecnológico, não é de cunho econômico, mas sim moral e político, uma vez que a classe dominante compreendeu que uma população que crê na disciplina moral do trabalho é muito mais conveniente e seguro que uma população produtiva, feliz e com tempo livre, afinal manter a população trabalhando massivamente permite que a classe dominante conduza melhor as rédeas sociais de acordo com seus interesses pessoais. O antropólogo sustentava ainda no mesmo artigo, considerações sobre o que ele classificava como trabalhos inúteis e como são muitas vezes gastas as horas de trabalho com outras coisas que não as atribuições previstas ao profissional, considerando é claro os trabalhos legitimados e aceitos moralmente como apropriados. Isto é, a relação entre o tempo que se está no trabalho, ou seja, o tempo oficial de se bater o "ponto" de entrada e saída, e o tempo que o profissional está de fato produzindo, não possui uma relação direta. Segundo ele, o trabalho poderia de fato ser efetuado em 15 horas semanais em média por indivíduo, porém “o restante do seu tempo eles gastam organizando ou participando de seminários motivacionais, atualizando o Facebook ou baixando séries de TV".

Tendo em vista que o artigo de Graeber foi analisado por nós de forma panorâmica, uma vez que as relações econômicas não são o nosso centro de 
debate, voltemos a nossa discussão central, que tem como fim entender os desdobramentos da noção romântica - a gratuidade ou inutilidade da arte - no Campo da Arte e do Campo do Design. Porém, o que podemos sustentar com essa rápida observação é o fato de que a superficialidade que analisamos as relações de trabalho dentro da nossa sociedade produz ou reforça noções míticas sobre a moralidade e a utilidade do trabalho aceito como apropriado, do mesmo modo que julgamos o trabalho artístico relapso ou vadio, apesar de muitas vezes essa relação ser oposta. O que ocorre de fato é que existe uma relutância em se enquadrar o artista como profissional legítimo dentro de uma sociedade industrial produtiva, noção essa que não ocorre apenas a partir da classe dominante, mas pelos próprios pares do Campo da Arte, que creem nessas noções e acreditam ser marginalizados e dispensáveis perante a sociedade industrial.

Não é incomum ouvirmos declarações que a arte não é prioridade dentro da sociedade, ou que dentre as necessidades humanas ela não é fundamental. Ora, de fato isso ocorre quando consideramos as necessidades sociais básicas como saúde, moradia e alimentação. Entretanto, desde que se mantenha a nossa cultura da forma como ela é, sempre existirá a parcela da população almejando consumir produtos artísticos ou simbólicos, ou como se entende hegemonicamente, coisas supérfluas ou sem finalidade utilitária. $\mathrm{O}$ que de fato ocorre é que a gratuidade do produto artístico pode ser avaliada por diferentes óticas, flexibilizada a partir do ponto de vista da classe social que a está analisando ou pelo entendimento do que de fato é a arte. O mesmo ocorre com os produtos carismáticos do design industrial, pois há quem possua objetos funcionais de luxo, e há quem tenha objetos convencionais comprados em qualquer loja de utensílios domésticos. O que nos cabe trazer como debate vai além do que se entende como gratuito ou superficial (decorativo) quando examinamos o objeto artístico ou industrial carismático, considerando apenas seus fatores estéticos, pois deste modo deixamos de aprofundar a análise do objeto como participante de uma sociedade, isto é, de uma cultura, e que o seu valor de troca simbólica é um fator crucial para compreendermos o que e, principalmente para quem, é útil ou não um objeto de arte.

Podemos iniciar uma reflexão pautada em um ponto de intercessão entre a investigação de Graeber a respeito dos empregos "inúteis" e do nosso entendimento sobre a noção romântica da figura e da profissão do artista, apesar 
do antropólogo não discutir diretamente o Campo da Arte. Observamos empiricamente dentro da universidade, mais especificamente entre alunos do Departamento de Artes e Design da PUC-Rio, considerações sobre o mercado de arte, e uma das pautas recorrentes é a argumentação afirmativa de que as artes plásticas possuem uma função social inútil, e em um momento de crise financeira a arte é a primeira "coisa" que se corta, pois ninguém precisa de arte para viver, e assim fica comprovado de igual maneira, que a sobrevivência por intermédio das artes plásticas está diretamente ligada à economia, à pujança da sociedade industrial e ao seu poder de consumo, e que provavelmente talvez essa fosse a razão por termos uma maioria de artistas hoje frustrados por terem ensaiado suas profissionalizações na carreira artística e que efetivamente não aconteceram.

Nos parece curioso como se constrói essa noção, visto que a história da arte está aí para provar que crises econômicas não são capazes de diluir a produção artística. Além disto, é um tanto superficial a colocação de que a arte é a primeira coisa que é cortada do orçamento em uma crise, afinal, do orçamento de quem? Levando em consideração o mercado milionário que as artes plásticas fazem girar, e que ela é um produto de alto luxo com valor especulativo enorme, os momentos de crise podem até favorecer o mercado de arte, afinal para alguns especuladores ele é mais seguro que a bolsa de valores, como quando ocorreu a crise de 2008, com a crise das "subprimes mortgages"17 na bolsa de Wall Street, momento em que o mercado de arte estava particularmente aquecido (como relata Sarah Thorton em Sete Dias no Mundo da Arte). Obviamente esse mercado milionário contempla apenas um número muito reduzido de artistas. Entretanto o Campo da Arte abrange também os artistas menores, as escolas de arte, as galerias, os museus, etc. Pensar na inutilidade da arte nos parece um tanto romântico, seria como admitir apenas a noção kantiana da gratuidade dos aspectos estéticos, ou "criativos" dos artistas, quando na verdade o objeto de arte também está dentro da cultura material, e é mercadoria.

Então a função da obra de arte na sociedade industrial é também de consumo, assim como dos outros bens industriais, e os objetos entendidos como objetos de design (apesar de que muito dificilmente alguém possa cogitar o desaparecimento da indústria). Enfim, sustentamos a noção de que a função da

17 Crédito de risco concedido a um tomador que não oferece garantias suficientes para se beneficiar da taxa de juros mais vantajosa (prime rate). 
arte possa até variar dependendo do espaço e da forma de remuneração esperada através dela, isto é, um leilão de arte e um museu operam de formas distintas, entretanto ambos possuem uma função social importante, tanto por razões comerciais quanto por razões simbólicas.

O que nos é fundamental neste relato é compreender a associação existente entre a noção romântica da profissão do artista ou do designer com a compreensão do que vem a ser um trabalho considerado legítimo na sociedade. Nos parece um tanto incoerente defender a distinção social do artista através da exaltação da criatividade, do dom e ao mesmo tempo desconsiderá-lo como um profissional sério que vende a sua força de trabalho. Do mesmo modo, parece-nos esdrúxulo justificar a moralidade do trabalho dentro de um sistema que submete o empregado a uma quantidade de horas trabalhadas que não são relativas à sua produção, isto é, que o empregado tenha uma demanda menor do que deveria ter e dessa forma despende seu tempo em tarefas inúteis, enfim, as duas coisas nos parecem hipocrisia.

Entender o mito da genialidade criativa do artista é também tentarmos desmistificar esse mercado, que é extravagante, de alto luxo e de fluxo de capital financeiro colossal. A venda de obras de artistas vivos com tamanha magnitude especulativa, tal qual os grandes nomes do Modernismo, não era usual até o final dos anos 1950, salvo algumas exceções como Picasso. Outro fator que mascara as intenções do mercado de arte e também do artista é a existência de intermediários na venda, como os marchands, que são sem dúvidas as figuras mais icônicas, os agenciadores dos artistas, aquelas que dão os valores a "criação imparcial", afinal outro mito muito difundido socialmente, é que o artista não sabe dar preço para a própria obra, pois ele se relaciona afetivamente com ela. O que ocorre é que por ser um mercado de alto luxo e para pessoas abastadas, o marchand já tem seus clientes em potencial, ele já circula nesses ambientes burgueses, além de funcionar como agente legitimador do artista em questão. $\mathrm{O}$ reconhecimento do artista apenas se dá se o mesmo for legitimado dentro do mercado comercial da arte e assim atribuindo "valor" à sua obra, ou seja, o valor financeiro ou comercial chancela o valor estético. Um exemplo que desconstrói por completo a ilusão do artista marginal dependente de um mecenas ou do mercado de arte e que não produz visando retorno financeiro é o contemporâneo Damien Hirst que em 2008 foi o "primeiro artista vivo que consignou diretamente suas obras a uma casa de 
leilão. Hirst recebeu $100 \%$ do preço ao bater o martelo, um negócio muito melhor que ele conseguiria com seus marchands". (THORTON: 2008, 53). Assim como Hirst outros artistas, hoje respeitados e inseridos dentro da noção passadista romantizada da arte, como Salvador Dalí ${ }^{18}$, também tiveram suas carreias estreitamente ligadas ao mercado de consumo de bens artísticos, isto é, tendo sua imagem diretamente vinculadas à publicidade e à televisão.

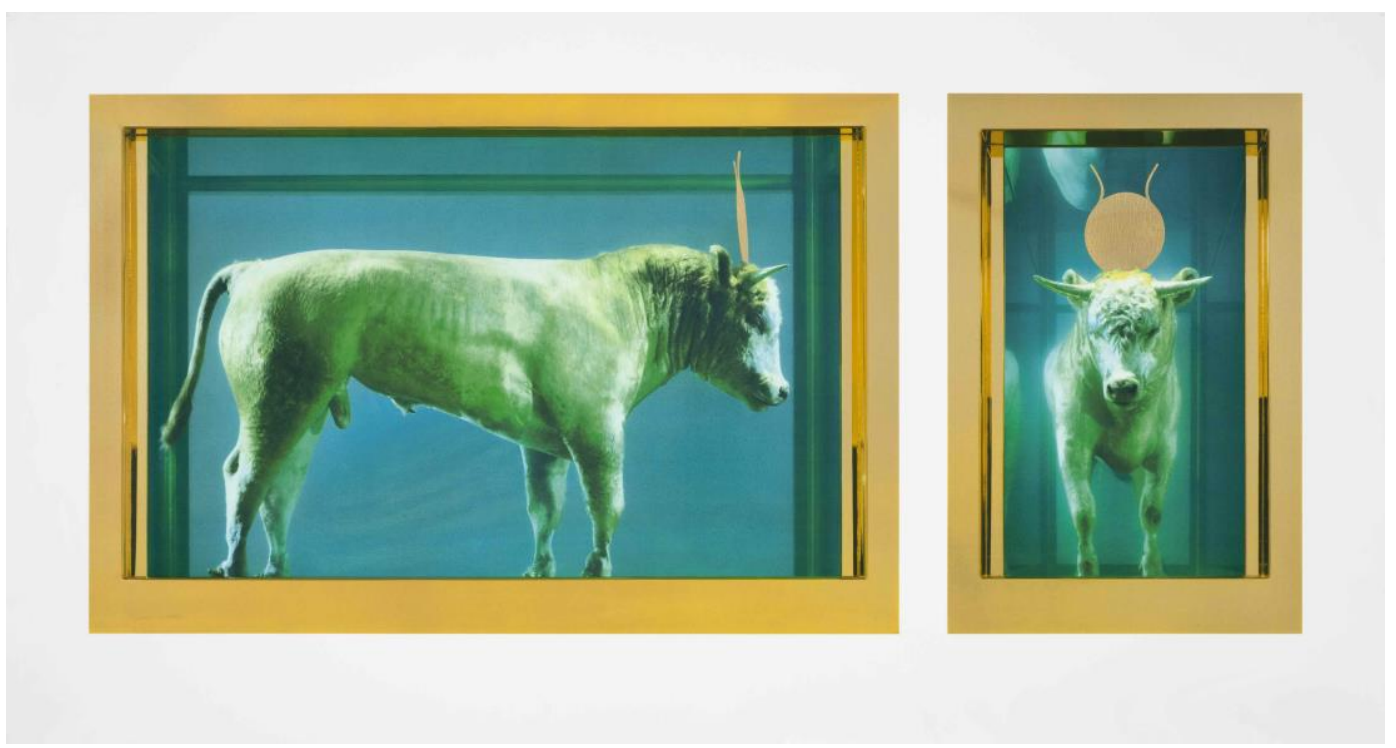

Figura 1 - The Golden Calf - Demian Hist. A obra está entre as que foram vendidas no leilão de Sotheby's de Londres e foi arrematada por 13 milhões de euros. (Fonte: https://www.publico.pt20080917culturaipsilonnoticiadamien-hirst-obtem-140-milhoes-de-eurosem-leilao-revolucionario-1343025. Acesso em 20/10/2018).

Compreender a arte tendo como foco apenas o mercado comercial de alguns artistas com fluxo de capital, bem como quem consome este tipo de objeto que está inserido dentro de uma cultura material, é outro modo - além do argumento histórico - fundamental para desnudarmos a noção do gênio criativo. O carisma sobre o trabalho de um determinado artista não é algo que ocorre puramente por questões estéticas, é necessário todo um respaldo social assegurado pelos agentes de legitimação para que o reconhecimento do autor vire de domínio social. Arriscamos afirmar que a crença no gênio marginal, com um dom inato e que foi reconhecido por um talento único e que a remuneração pelo trabalho foi

18 Utilizamos aqui Salvador Dalí como exemplo pelo fato do artistas ter vinculado sua imagem a inúmeras propagandas comerciais, como para a Chocolates Lavin, a Alka-Setzer e o conhaque Veterano (https://www.youtube.com/watch?v=Pa2rwk-SlCo. Acesso em 10/09/2018). 
apenas reflexo natural, despretensioso e espontâneo, chega a ser, minimamente, inocente.

Se no Campo da Arte isso é difundido pelos motivos que analisamos acima, arriscamos mencionar que o Campo do Design também bebe da mesma fonte, apesar de ter sido legitimado como profissão muito posteriormente. Quando tratamos da prática do design, falamos de desenvolvimento de produtos, de bens de consumo, dentro de uma sociedade industrial capitalista. Trata-se de um processo de concepção, fabricação e distribuição de objetos da cultura material cujo o processo integra uma vasta gama de profissionais, além do próprio designer, que fica responsável pelo desenho ou concepção do produto, mas não possui a autonomia das escolhas finais, pois geralmente elas ficam a cargo dos donos das empresas. O trabalho do designer é voltado diretamente para isso que eles denominam "demanda de mercado", isto é, algo que longinquamente poderíamos chamar de real solicitação, mas para a obtenção de lucro. O design é compreendido pelo público e pelos designers como uma ferramenta para incremento da mais valia. Contudo, havemos de nos lembrar que os pares do campo cortejam o mito da superioridade criativa tal qual os artistas, e nos desperta interesse esse tipo de aproximação entre as duas práticas. Tal como no caso do designer, curiosamente o trabalho do artista também é uma produção coletiva onde o autor é responsável apenas por uma pequena parte de todo o processo da produção da "obra", mas nesse segundo caso essas circunstâncias históricas são silenciadas e esses detalhes de homologia entre a prática do design e a prática da arte, são tratados de forma velada, e tal como no caso do designer, tem-se a impressão de que a venda é consequência e não objetivo primordial do artista. Um ponto de divergência entre a prática do artista e do designer, é que de certa maneira está legitimado que para o designer, seria natural afirmar que ele deseja ser remunerado pelo trabalho que realiza. Essa diferença simbólica de integração ao mercado industrial também se dá com a prática do artesanato, que diferentemente das "obras" de arte, também é entendido como produto ou mercadoria, destinado a venda imediata, apesar de possuir um caráter decorativo, ele não ocupa o mesmo espaço simbólico da arte, e ao mesmo tempo sua produção é em pequena escala, em oposição a produção industrial do objeto de design.

Sabemos também que existiram alguns movimentos para aproximação 
teórica das noções que possibilitam uma definição destes campos empregando os mesmos critérios, como por exemplo o caso da Bauhaus, que segundo Canclini, desejou conter a diferenciação de classes que ocorre entre o artesão e o artista, aplicando uma experimentação formal em um design industrial inovador e urbano concomitantemente com os avanços das vanguardas artísticas na cultura cotidiana, o que culminaria em uma comunidade de artífices integrados dentro das suas práticas laborais (CANCLINI, 1989: 41). Entretanto este tipo de experiência se torna quase utópica e de pouca repercussão dentro de uma sociedade capitalista e de modo geral para sanar a curiosidade intelectual das pessoas.

Concluímos então, que a ideia de dom e criatividade, ligados a produção de objetos da cultura material, está inserida em diferentes campos, tal como na arte (lugar que ela é oriunda), no design e no artesanato. E independentemente das formas de produção e de clareza intencional ou velada em relação à espera de um retorno financeiro pelo trabalho, ambas defendem ideologicamente o mito do gênio criativo, tão enraizado hoje no discurso hegemônico dos pares desses campos correlatos, sem admitir que quem de fato cria as demandas do mercado são os financiadores em potencial, isto é, os donos de indústrias no caso do design, ou os compradores das obras de arte ou das peças de artesanato, fazendo-nos assim "esquecer" que o que chamados de criatividade na verdade são fatores externos ao criador, mas sim demandas sociais legitimadas por um mercado que é gerido por uma pequena parcela da população que financia isso que chamamos de arte ou design.

\section{2}

\section{O trabalho coletivo e as expressões individuais do criador moderno}

A noção mítica de genialidade e dom presentes no Campo da Arte, como vimos anteriormente, é fruto de um período histórico específico e se perpetua até os dias de hoje, assegurado por um mercado de arte que preza pela permanência desta crença. Ocorre também que essa noção foi herdada por outros campos para justificar a produção de bens de consumo sob um olhar romântico, atribuindo ao designer ou ao artesão, supostas características que os colocam em um lugar social diferente dos demais trabalhadores, agregando assim valor estético e financeiro a 
produtos que de fato são apenas reproduções industriais produzidos $\mathrm{e}$ comercializados com interesse comercial dos donos das industriais. Com isso, fica claro para nós a intencionalidade de se perpetuar essa visão romântica acerca do artista, e em que momento se iniciou.

Outro ponto chave que se insere nessa mítica moderna do artista genial é a crença equivocada de que ele, como trabalhador autônomo (até mesmo a palavra trabalhador nos parece estranha quando falamos de trabalhos de arte) é um produtor individual, que trabalha por conta própria, sem interferência externa de outros indivíduos, dominando o processo completo de produção das obras de arte. Afinal, se julgamos que alguém se torna artista por ter nascido com esse dom por alguma razão espiritual, seja ela astrológica ou religiosa, defenderemos o fato de que a expressão da arte é algo que se dá no campo das expressões pessoais e subjetivas do artista. É assegurar que o "fazer arte" é intrínseco ao autor da obra, e que nela retrata emoções próprias, onde as vivências íntimas têm mais peso dentro da produção do que toda a sociedade que o cerca. Seria o mesmo que disséssemos que a criação é algo individual, que a criatividade, o talento e o dom são de domínio único do autor e dessa forma apenas ele detém o poder de transformar suas ideias tão individuais, em expressão palpável, ou seja, objetos compreendidos como obras de arte.

Para desmontarmos essa noção hegemônica de que o trabalho artístico é individual, e defendermos que assim como todas as outras formas de trabalho ele é coletivo, faremos uma análise do Campo da Arte $^{19}$ e como fatores externos a ele são fundamentais para o seu funcionamento de tal modo que se tornam colaborativos na sua produção. Para isso empregaremos os seguintes pontos: i) a tecnologia, ii) as instituições sociais e iii) os fatores econômicos ${ }^{20}$ externos a produção artística.

Quando tratamos da noção teórica do Campo da Arte, não estamos apenas nos referindo à produção artística visual, as artes plásticas, mas também estamos considerando na questão, o teatro, a música, o cinema, a dança e a literatura. A

\footnotetext{
${ }^{19}$ Pensamos aqui em uma noção universal que nomeia algumas práticas laborais como produtoras da arte e que nomeamos juntamente com Pierre Bourdieu como pertencentes ao Campo da Arte, mas nele operam diferentes agentes produtores de diferentes gêneros artísticos, tais como a literatura, a música, a gravura, a arquitetura, as artes visuais etc.

20 Janet Wolff em A Produção Social da Arte defende as três classificações: tecnologia, instituições sociais e fatores econômicos, para explicar a noção de colaboração e coletividade no Campo da Arte (1981: 47-59).
} 
noção de individualidade produtiva, sem dúvidas está mais presente dentro das artes plásticas e da literatura, ou poesia, onde acreditamos que o autor é detentor único da criação. Nas Artes de Espetáculo, como nas apresentações de teatro, música ou dança, nos é mais nítida a separação do trabalho entre outros indivíduos, bem como na produção de filmes. No teatro por exemplo, podemos elencar diversos profissionais diferentes responsáveis pela exibição de uma peça, tendo como protagonistas além dos atores (que têm o contato mais direto com o público), o diretor, o roteirista, o iluminador, o figurista, além de outros que variam com a proporção e a temática da composição. Porém, esta lista do que chamamos de “equipe de apoio", não se limita aos profissionais ligados diretamente à peça, no instante do ato da apresentação, mas também a outros mediadores mais ocultos, como o dono do teatro, a instituição financiadora, a equipe de imprensa e marketing que trabalham na divulgação, o crítico que legitima sua qualidade e assim atrai o público para as salas de espetáculos.

No cinema essa equipe é ainda mais extensa, basta apreciarmos os créditos "baixando" no final dos filmes quando as pessoas estão indo embora, além de depender fundamentalmente também dos recursos tecnológicos disponíveis, o que expande ainda mais a rede de colaboradores na produção do filme. Apesar do Oscar de melhor filme ser entregue ao diretor, ele não detém sozinho o livre arbítrio da direção, e isto não está relacionado apenas ao elenco e a enorme equipe que está no set no momento da filmagem, mas também aos agentes legitimadores e financiadores de um filme. Sabemos que existe ainda a censura direta e a imposição pelo silenciamento de determinados temas muitas vezes imposto por instituições sociais. Mas há também a censura indireta, que está inculcada socialmente em nós mesmos e nos impede de possuir o livre arbítrio completo. Por exemplo, questões religiosas e políticas muitas vezes são um campo minado, e é necessário usar cautela para se explorar. Caso contrário seria impossível dispor de uma instituição financiadora para a produção do filme, ou caso haja aceitação para a produção, o público e os críticos se encarregam de diminuir a distribuição, apresentando rejeição à temática. De todo modo, por vivermos em sociedade, sabemos os limites que a expressividade individual pode alcançar para que haja uma aceitação do mercado e do público. E obviamente quando se trabalha com Arte de Espetáculo esperamos que a recepção seja favorável. Janet Wolff sustenta, em A Produção Social da Arte, a coletivização das Artes de Espetáculo, uma vez, 
que para que se elabore uma apresentação pública, é necessário uma grande variedade daquilo que Becker chama de "pessoal de apoio", não se detendo assim apenas no trabalho do autor do espetáculo. (WOLFF, 1981: 45).

É de comum acordo entre os pares e para uma parte do público que um diretor não é o único criador de um filme, bem como um maestro regente não é uma figura isolada em um concerto, entretanto são esses profissionais que acabam por receber a maior parte dos louros pela criação. Dentro das Artes de Espetáculo não há objeções quanto à ideia de trabalho coletivo. Poderíamos aqui apontar outras questões referentes às apresentações artísticas e a equipe de apoio responsável por sua realização, que se subdivide entre profissionais da área técnica e por outros artistas, que não estão em holofote principal. Tomemos como exemplo os cartazes oficiais desenvolvidos para filmes exibidos em cinemas, onde certamente estarão presentes o nome do diretor e dos atores principais, mas o fotógrafo, ou ilustrador, ou designer responsável pela capa dificilmente será nominado como tal, ou terá um reconhecimento similar aos que os nomes estão escritos. Existe uma hierarquização dentro da colaboração artística, no qual poucos são responsabilizados por trabalhos referentes a equipes de apoio muito grandes e que envolvem profissionais de diferentes áreas, direta ou indiretamente. Entretanto assim como no mercado comercial da arte, ou no desenho industrial, as Artes de Espetáculo também estão submetidas as empresas de patrocínio ou instituições sociais que não apenas legitimam a obra produzida ou a financiam, tal como a gigantesca e teratológica Fundação Roberto Marinho que está praticamente por trás de tudo que se faz em termos de cultura aqui no Brasil, mas também tem o poder de tomar decisões que interferem diretamente no produto artístico visando maior rentabilidade, como por exemplo a escalação de um ator que aumente os números de bilheteria e consequentemente o retorno financeiro aos donos das empresas.

Se nas Artes de Espetáculo fica claro para nós o caráter colaborativo do trabalho e a subdivisão do mesmo por diferentes profissionais, nas artes tidas como autônomas essa evidência é mais nebulosa nos dias de hoje. No passado, isto é, durante o Antigo Regime, a pintura e a literatura eram diretamente ligadas ao sistema de patrocínio e encomenda das obras, logo não se entendia a figura do artista como um ser criativo autônomo, se entendia a prática da pintura, da escultura ou da literatura como um simples ofício e que qualquer um poderia 
realizá-lo. Quando ao final do século XVIII o artista se emancipou das guildas e o sistema de mecenato foi substituído pelo crítico comercial, modifica-se, portanto, a relação compreendida como prática artística, outrora vista unicamente como coletiva. Onde antes a temática das obras era fornecida pelo mecenas ou comanditário, na Idade Moderna ela passa a ser percebida como a livre inspiração do criador. De fato, o ato da pintura (tomaremos esta prática como exemplo principal), é muitas vezes individual e envolve apenas o artista e a tela a ser pintada. Entretanto entender a prática artística apenas no momento da concepção da obra é uma percepção que consideramos superficial. É necessário considerarmos quais aspectos levaram a escolha da temática que será pintada, por quem e em que lugar este trabalho será comercializado, as tintas e pincéis utilizados na confecção e outros inúmeros aspectos fundamentais que fazem da criação pictórica um trabalho coletivo.

Novamente precisaremos analisar o mercado da arte para justificarmos o trabalho da pintura como uma produção coletiva. Assim como nas Artes de Espetáculo, na pintura ou na escultura, a distribuição, legitimação e venda de obras de arte não está a cargo unicamente do artista, mas sim de uma vasta cadeia de profissionais que são envolvidos no processo de comercialização. Porém, esta etapa se dá a posteriori da produção da obra. Entretanto o trabalho já é de cunho coletivo a priori, isto é, deve se considerar a formação do indivíduo como artista (não nos referimos aqui unicamente a formações acadêmicas, mas da profissionalização do indivíduo como pintor), o que está sendo produzido dentro do Campo da Arte em momento coetâneo a ele e os materiais que o mesmo utilizou para a realização do trabalho. Certamente o que é mais ou menos vendável na pintura se altera de acordo com a época, cabe ao pintor compreender o que o mercado artístico está valorizando para que se tenha êxito ou "apoio" para a venda da obra. Logo, a dita "expressão individual criadora do artista" deve estar minimamente alinhada a produção artística vigente para que se alcance um valor comercial dentro do mercado de arte. Essa simples conclusão por si só desmonta a ideia de que existe a livre criação pessoal, que se pauta apenas na inspiração pura. Se vivemos em sociedade, somos condicionados por ela, sofremos processos de inculcação muitas vezes imperceptíveis que nos levam a "criar" ou escolher entre uma coisa e outra. $\mathrm{O}$ mercado comercial na ponta do processo exige de forma velada que o artista se equipare as tendências comerciais, caso contrário as 
possibilidades de se projetar como artista ficam reduzidas, ao passo que essa legitimação ocorre através de marchands, galerias de arte, feiras, bienais, etc.

A própria formação do artista como tal, principalmente aqueles que legitimaram a prática dentro de um meio acadêmico como as universidades ou escolas de arte, já evidencia a colaboração na criação. Quando um professor, por exemplo, tece considerações positivas ou negativas em relação à obra apresentada, por si só, isso já torna-se uma influência externa. E, apesar de parecer óbvio, os artistas analisados como referência histórica também coletivizam a prática artística, e modificam aquilo que é compreendido como uma expressão individual intrínseca. Esses pontos de consideração são válidos principalmente entre os profissionais do campo que trabalham com arte dentro dos moldes tradicionais, tais como conhecemos, isto é, a pintura, a escultura e a literatura. Entretanto quando consideramos também aqueles ditos artistas que ingressam para o Campo da Publicidade ou da comunicação visual, a evidência da colaboração e da coletividade é mais nítida, e podemos chamá-la também de briefing. O briefing direto ${ }^{21}$ na arte hoje, nada mais é que o equivalente da encomenda do mecenas no Antigo Regime. Por exemplo, quando um artista é contratado para ilustrar a capa de um disco de música, ou um cartaz de cinema (no próximo capítulo trataremos especificamente desta questão, mas cabe agora nos determos nos aspectos referentes ao trabalho coletivo). Entendemos que o trabalho realizado explicitamente mediante briefing, é uma atribuição do designer. Profissional este que também é considerado socialmente como um trabalhador autônomo, apesar de ser evidente que o objeto industrial é compreendido como um objeto da cultura material de forma mais clara que o objeto de arte. Mas tal como já foi analisado mais acima, algumas características vinculadas aos artistas são também atribuídas ao designer, e da mesma forma ele é entendido como criativo e autônomo. Entretanto como poderíamos defender a existência de uma autonomia se na própria metodologia projetual, amplamente defendida pelos pares do campo, o briefing aparece como a primeira etapa para o desenvolvimento de um projeto? $\mathrm{Na}$ nossa compreensão, a partir no momento em que um financiador submete o designer a um "roteiro do que se espera como resultado", a radical autonomia

\footnotetext{
${ }^{21}$ Mencionamos briefing direto considerando que o indireto é aquele que o mercado comercial impõe de forma velada. Ou seja, aquilo que é vendável em determinado momento, e que é compreendido como tal pelo artista.
} 
individual do projeto deixa de existir, admitindo-o sem sombra de dúvidas como coletivo, logo não é necessário que nos estendamos mais acerca do trabalho coletivo no Campo do Design, ou da publicidade por exemplo, que funciona sob a mesma estrutura de desenvolvimento de projeto. Além disto, não é apenas na encomenda do projeto que o trabalho torna-se coletivo, mas também pelo fato que a criação não pode se dar de forma totalmente livre, pois questões como custo, ou viabilidade de produção industrial que são essenciais para se definir a estética, ou os materiais ou a funcionalidade do objeto, submetendo assim o designer a uma série de questões financeiras mais importantes que a fabricação de uma "ideia" criativa.

Compreender que a autonomia é uma noção fantasiosa não apenas para quem produz, mas também para quem consome objetos, é de extrema importância para que possamos debater a lógica do mercado capitalista, que se sustenta a partir da padronização do comportamento que leva a uma melhor especulação produtiva por parte dos donos das indústrias, que em linhas gerais também criam as necessidades e nos convencem de que elas são verdadeiramente essenciais, nos tornando assim reféns do consumo de determinados objetos. Vale frisar que a forma como é conduzida a produção e a venda de bens de consumo mascara o domínio total da indústria. $\mathrm{Na}$ moda por exemplo, somos bombardeados de propagandas que ditam qual será a cor da próxima estação. Logo acreditamos que quem define esta escolha são os renomados estilistas ou fashion designers da alta costura. Isso é, é de comum acordo a crença em uma hierarquização da moda que tem como topo profissionais renomados da alta costura, exemplificando, se um desfile da Chanel para o Paris Fashion Week traz modelos vestindo roupas na cor verde militar, é provável que esta cor vá se destacar a posteriori em diversos desfiles de outros costureiros conceituados, em seguida vai aparecer nas lojas de alto valor financeiro, seguidas de lojas de departamento até as lojas mais populares, onde então já perderam o valor simbólico da distinção social e não mais são um artigo consumido por pessoas que entendem de moda e possuem um alto poder aquisitivo de compra e assim se diferenciam dos demais consumidores, ocorrendo assim uma desqualificação do verde militar pelo seu consumo popular. O que não nos é apresentado com clareza na verdade, é o fato de que a decisão pela cor que será tendência - trends and forecasts - na próxima estação e que girará uma grande parcela do mercado da moda não é uma decisão das marcas de alto luxo, ou alta 
costura, mas sim da indústria química que tem o poder de definir, a partir da sua própria produção previamente estabelecida, quais tecidos serão fabricados em quais cores para a produção e o desenvolvimento de coleções das grandes marcas $a$ posteriori, e que depois ganharão espaço em grande parcela da cadeia produtiva de roupas. Esse exemplo nos é útil no sentido de usá-lo como embasamento para discutirmos de que forma a indústria tem influência de modo mais direto nas nossas escolhas de consumo do que pudemos presumir sob nosso olhar romântico a respeito das escolhas pessoais. Logo, podemos nos julgar distintos no momento que estivemos entre as primeiras pessoas a assistir ao desfile da Chanel no Paris Fashion Week, e considerarmos que a escolha de se usar o verde militar antes da grande maioria das pessoas, provém de uma sensibilidade inata para se entender de moda, e nos julgarmos únicos ou formadores de opinião acerca do que seria um gosto sofisticado para comprar roupas. Porém, a análise da cadeia produtiva prova que a lógica do mercado opera de tal forma que somos condicionados a agir desta maneira e seguir perpetuando essas crenças, afinal, isso é vantajoso principalmente para quem vende. Essa relação se dá não apenas com roupas, mas com qualquer bem da cultura material e imaterial, assim como com os posicionamentos ideológicos e comportamentais individuais.

O que desejamos evidenciar foi o declínio da certeza do trabalho como produção coletiva, assim como crença na individualização do sujeito enquanto ser social. Segundo Norbert Elias em seu livro A Sociedade do Indivíduo, a formação da estrutura social, bem como as mudanças nela ocorridas, não dependem das pessoas como partículas individuais e, do mesmo modo, não pode se compreender o sujeito como ser isolado. A existência social só pode se dar em conjunto, com a relação entre os indivíduos e não de forma individual, e quanto maior for o intercâmbio entre as pessoas, maior e mais estreita será a ligação entre elas, e apenas dessa forma podemos compreender a sociedade como um todo, cuja formação se dá de forma alegórica e sem planejamento prévio, "não há identidadeeu sem identidade-nós" (ELIAS, 1987: 152).

Se na Antiguidade era evidente que as ações eram comunais, hoje já nos temos como detentores totais das nossas escolhas. O trabalho manufaturado do Antigo Regime só poderia se dar uma vez que fosse integrado entre os moradores de uma comunidade, assim como se acreditava que Deus que traçava o destino dos homens, sendo eles incapazes de ter decisões próprias uma vez que eram regidos 
por uma força maior. Vale ressaltar que não sustentamos que esse modelo de sociedade é melhor ou se aproxima mais da crítica a autonomia, afinal ambos são carregados de ideologias constituídas por instituições detentoras de um enorme poder de manipulação, seja a igreja ou a indústria e a mídia. Utilizamos esta comparação em função de estabelecer um pensamento crítico consistente em detrimento aquilo que estamos utilizando como argumento. Hoje, ainda temos as instituições religiosas extremamente eficientes em relação ao domínio social, porém contrabalanceadas com o poder que a indústria exerce, e obviamente o teocentrismo já não é mais tido como verdade, sendo assim, o homem moderno antropocêntrico entende seu livre arbítrio perante Deus, mas não tem a mesma clareza em relação a sociedade capitalista. Poderíamos traçar um paralelo, observado por nós e utilizado aqui apenas a fim de exemplificar, entre a crescente crença na astrologia pelo homem moderno e o individualismo dele em relação a sociedade. Se nas religiões o coletivismo está presente, uma vez que os dogmas de cada uma são teoricamente iguais para todos os fies, na astrologia o mapa astral é algo totalmente individual, que é gerado de acordo com a data, a hora e o local de nascimento de cada pessoa. Logo, se justifica nos astros características unitárias para cada sujeito, e se estabelecem pontos de conexão entra pessoas de mesmo signo, excluindo-se assim que o comportamento é fruto da estrutura social e assegurando a confirmação a individualidade.

Nos parece ingênuo a sustentação de que alguém do signo de capricórnio será mais pragmático por questões astrológicas e que todas as outras do mesmo signo terão as mesmas características independente se ela trabalha na bolsa de valores de Nova Iorque ou em uma plantação de arroz no interior da China. A coletivização comportamental dos signos também possui grandes lacunas em relação à compreensão do homem como ser social e dependente diretamente da estrutura social para se formar como indivíduo. Do mesmo modo que se entender como único e passível de todas as escolhas pessoais porque "optou" por usar Iphone, dirigir um carro elétrico, gostar de Basquiat, de filmes do Coppola e ouvir Devendra Banhart, por mais distante do mainstream que isso possa aparentar, não deixa de ser uma inculcação social do comportamento. Apesar de parecer que apenas a cultura de massa é capaz de manipular as pessoas, por ter recursos ou uma divulgação muito maior nos meios de comunicação, aquilo que consideramos como alternativo também opera por uma mesma lógica, afinal o juízo de gosto 
também está relacionado com a luta de classes e dessa forma com a diferenciação social.

Julgamos que é preciso lembrar que aquilo que tem a intenção de ser distinto do que é consumido pela camada popular, possui também uma lógica de propagação midiática e comercial diferente. Então, por mais que se acredite que os fãs do Romero Britto sejam mais influenciados pelos agentes de comunicação do que os apreciadores de Tunga, devemos ter a clareza de que de fato a arte contemporânea é um espaço elitizado e hostil, e como defende Bourdieu, é necessário um domínio dos códigos estéticos que são fruto de uma capital escolar, diretamente ligado com o capital financeiro. Então, o interesse pelo reconhecimento de massa de determinados artistas se dá de forma distinta de outros, tal como ocorreu como o nome de Romero Britto que não se destaca apenas pintando quadros, mas também vendendo suas criações para marcas de produtos de higiene e limpeza estamparem em seus rótulos, por exemplo. Logo, é indiscutível que existam diferentes abordagens de propagação de trabalhos de artistas distintos, mas ambas são programadas para atingir determinado públicoalvo, que se diferem por questões de classe social e assim de distinção de status social. Desse modo, o que se consome em cada classe tem relação direta com poder financeiro e escolar, e dessa forma a imposição do gosto pelo mercado industrial e educacional opera de formas dispares, mas produzem um resultado semelhante, que nada mais é que a manipulação do consumo.

Para finalizar as considerações sobre a noção do trabalho coletivo do artista e do designer, vale frisar que estes profissionais que trabalham sob uma ótica social similar e desenvolvem produtos da cultura material. Assim necessitam seguir determinadas regras veladas presentes na sociedade para que a venda do objeto tenha êxito. Já o artesão, que é regido pelos mesmos princípios comerciais, opera tradicionalmente de outro modo. Diferentemente das considerações feitas em relação à crença na autonomia do artista e do designer, as noções que precedem o artesanato o determinam como sendo fundamentalmente coletivo. Por não ser um saber institucionalizado, e ser transmitido de forma assistemática através de gerações dentro de pequenas comunidades, ele se admite coletivo. $\mathrm{O}$ artesanato geralmente não é nominado de acordo com o autor individual, mas sim pela região que ele foi produzido, da mesma forma que não há grande distinção entre as peças produzidas por pessoas diferentes, elas seguem um mesmo padrão 
estético, não havendo assim a pretensão de que se revele uma expressão pessoal do criador. Aquilo que discrepa, tal como o caso de um artesão famoso como Mestre Vitalino, passa para o Campo da Arte. $\mathrm{O}$ artesanato não possui a crença na essência individual criativa e expressiva tal como a arte, ele é abertamente compreendido como mercadoria que transmite através dos objetos a identidade de um povo (falamos aqui do artesanato produzido e comercializado como objetos decorativos e não aqueles de cunho funcional, ritualístico ou espiritual utilizados internamente nas comunidades em festejos e celebrações). As diferenças estéticas entre os objetos de artesanato se dão mais por regiões e comunidades diferentes do que entre produtores de um mesmo local, onde todos os artesãos se identificam principalmente dentro de um mesmo padrão visual. A noção de autoria dentro do artesanato ocorre à medida em que alguns artesãos sofrem processos de legitimação que acarretaram em maior visibilidade e assim suas peças ficam na fronteira entre a obra de arte e o artesanato, sendo complexa a compreensão plena sob sua classificação. Mas, o que nos interessa de fato dentro do processo artesanal é como ele trabalha de forma colaborativa, diferenciando-se assim de demais práticas tidas como criativas. "Um índio nunca é menos livre do que quando está só" (CANCLINI, 1982: 83).

Por fim, tendemos a acreditar que as práticas criativas são processos autônomos definidos unicamente pela expressão individual do criador, que elas são mais relacionadas com uma forma essencial de demonstração sentimental daquele que o faz, do que com o contexto social e histórico que ele está inserido. Nas Artes de Espetáculo nos fica mais evidente a colaboração e coletivização da montagem de determinada peça, concerto ou filme, mas ainda assim a tendência hegemônica é atribuir a criação do roteiro, ou da música à apenas uma pessoa (o compositor), entendendo que o restante da equipe tem participação ativa no momento do espetáculo e não na concepção e desenvolvimento da parte criativa previamente escrita. Bem como no Campo do Design, entende-se que a elaboração da forma e função se faz por um indivíduo e que a colaboração se dá na fabricação do objeto. Já nas artes plásticas, na literatura e na poesia, esta noção está muito mais enraizada e dessa forma muito mais difícil é a compreensão de que apesar do ato da pintura ser em parte individual, o artista é influenciado socialmente e é isso que torna seu trabalho coletivo, que o faz mais construído pelo sistema social do que por questões individuais de expressividade. Em suma, vivemos em uma sociedade 
extremamente individualista, e isso de fato se reflete na crença no trabalho autônomo e autoral, que se desenvolve unicamente por vontade de um indivíduo, porém não somos seres isolados, vivemos em sociedade e a prática criativa se dá através dela e para ela, ou seja, o trabalho artístico (isto é, o profissional artista, e não o indivíduo que desenha por hobby e guarda seus esboços na gaveta, enquanto na vida profissional vende sua força de trabalho em outra área, que é de fato sua arrecadação financeira) querer um público consumidor, que funcione dentro de padrões de comportamento antecipadamente e socialmente construído que aceita e aprecia certas coisas e outras não. O artista de certo modo "trabalha" para esse público, e mesmo que não seja imposto diretamente a ele qual deve ser sua temática de produção estética, conceitual ou linguística, sabe-se o que é ou não rentável, o que é ou não consumido, e essa forma o mercado criativo já está sujeito a determinadas barreiras previamente estabelecidas, mesmo que nada precise ser dito diretamente, derrubando assim a noção do trabalho individual, toda forma de trabalho é essencialmente coletiva.

\section{3}

\section{A cultura erudita e a cultura popular - Uma visão a partir das definições de Canclini}

Parece-nos razoável que quando desejamos debater aspectos referentes à cultura, precisamos primeiro compreender o que essa palavra representa, ou definir qual das suas significações se enquadra melhor no conceito abordado. Sua delimitação é imprecisa e há séculos pesquisadores tentam exprimir teoricamente o que de fato é cultura, quem a influencia e a domina e como aplicar essa palavra cotidianamente ou em estudos aprofundados. Os antropólogos Alfred Kroeber e Clyde K. Klukhohn, por exemplo, reuniram em 1952, quase trezentas maneiras de se definir cultura, o que nos atenta quanto a necessidade de análise desta palavra para compreender qual dentre tantas explicações distintas se encaixa em que contexto, ou melhor se conecta com linhas de pesquisas diferentes.

A busca das Ciências Sociais em definir cultura nos abre inúmeros caminhos para o debate da significação deste termo, bem como para as aplicações cotidianas despretensiosas e espontâneas, na qual a própria pluralidade de culturas 
e os meandros atuais que as tornam unidas, ou desconectadas ou miscigenadas, tornam ainda mais complexo esse entendimento. Podemos listar hoje quais são as principais narrativas cotidianas quando tratamos de cultura, mas não que isso seja uma verdade epistemológica, pois uma definição com pretensão de ser completamente verossímil é difícil, ao ponto que essa noção é parcial.

No livro Diferentes, Desiguais e Desconectados (2015) de Néstor García Canclini são apresentadas duas noções cotidianas do que é cultura diante de uma visão hegemônica. A primeira está ligada à educação, sofisticação e informação, ou seja, quando falamos de cultura como acumulo de conhecimento e intelectualidade. Esta definição nos é muito familiar no uso coloquial da palavra, mas ela está ligada diretamente a filosofia idealista. Canclini afirma que "a distinção entre cultura e civilização foi elaborada pela filosofia alemã no final do século XIX e no princípio do século XX” (2015: 37). Resumidamente, esta definição diferencia cultura de civilização, onde a cultura pertence a um status mais elevado, algo lapidado por um artista, por exemplo, e que alcança uma diferenciação social e uma definição de obra de arte. Já a civilização é aquilo que é modificado da natureza pelo homem através de um conjunto de técnicas, entretanto não alcança esse valor da beleza sublime da obra de arte, por tanto não é cultura.

Podemos destacar várias críticas a essa forma de pensamento, a esse uso coloquial da palavra cultura sendo ligado ao domínio do saber e da intelectualidade. O primeiro ponto que podemos discutir é uma divisão de trabalho neste conceito, na qual se diferencia o artista dos demais trabalhadores, dando o status de cultural à sua produção, o que obviamente está ligado a uma luta de classes e valores políticos e comerciais. Outra questão é quem legitima aquilo que pode ser considerado cultura dentro deste aspecto. Quem são aqueles que ditam os critérios disso que é a cultura e o que não é? Para que haja produtos civilizatórios que possamos chamar de culturais é porque existem aqueles que são chamados de não culturais, e então a questão passa a ser em que medida isto é uma escolha social espontânea, ou é a voz de uns poucos legitimados? Parece-nos que definição de cultura é sempre uma escolha econômica e política daqueles que detém poder para consagrá-la. Se analisarmos isto dentro da história da humanidade, sob nossa ótica latino-americana, vemos que os homens e mulheres tidos como cultos são aqueles que possuem conhecimentos e gostos vinculados principalmente à história 
moderna do Ocidente, desenvolvidas na área europeia ou norte-americana. Ocorre que para obterem esses conhecimentos tidos como "cultos", precisaram de toda uma organização social, de uma estrutura social, para recrutarem e formarem neófitos dentro desses postulados. Do mesmo modo, tiveram que possuir todo um aparato de organização para que esses valores fossem reproduzidos e ampliados e ao fim e ao cabo parecerem naturais para aqueles que tiveram oportunidade de fazer parte dessa parcela social.

Diferenciamos também os tipos de cultura. Quando falamos de alguém culto, imaginamos naturalmente uma pessoa letrada, com conhecimento avançado de literatura estrangeira, de música clássica, de idiomas, cinema, filosofia, ou arte, enfim, tratamos de uma definição altamente sofisticada e elitista, uma herança da visão dos nobres do Antigo Regime. A classe trabalhadora dificilmente tem disponibilidade de tempo ou recursos para acessar essa posição social daquele tido como culto.

Para nós, latino-americanos esta análise ainda se dá de forma mais complexa, pois atribuímos esse adjetivo de culto a conhecimentos de valores que são distantes da nossa sociedade, e somos conduzidos a absorver a cultura de outrem e acreditar que ela é superior. É claro que existe um monopólio econômico das grandes potências, atualmente os EUA, que nos induz a isso. Mas o fato é que sob essa definição do que é cultura acabamos criando um subtítulo para a nossa própria sociedade, chamada de cultura popular.

No Brasil, por exemplo, tudo aquilo que não tem influência americana ou europeia dentro dos Campos Artísticos é tipo como cultura popular. Na realidade, poucas são as manifestações populares que não têm interferência externa no nosso país devido a nossa história, mas existem aquelas que já estão tão enraizadas que nomeamos de brasileiras. E mesmo dentro do país existe uma colonização cultural do Sudeste para o Nordeste, onde o primeiro por sofrer mais atuação de culturas exteriores, considera o segundo mais 'popular'. Seria ingênuo da nossa parte acreditar que se há uma distinção de nomes não há uma diferenciação de status social de quem produz e quem consome cada uma.

Por fim, voltando à noção da filosofia idealista de que a cultura é algo ligado aos aspectos intelectuais e educacionais e vinculados ao conhecimento histórico e artístico de uma determinada produção Ocidental moderna europeia e estadunidense, podemos constatar que esta noção é taxativa e elitista e por mais 
que usemos isso cotidianamente ela não é suficiente para compreendermos o sentido da palavra cultura.

Canclini também apresenta outra noção frequente da palavra cultura, que trata de um conjunto de usos científicos que surgiu contra esses usos cotidianos, simplórios ou idealistas. Segundo ele existem dois confrontos principais que se submetem ao termo, que são natureza-cultura e sociedade-cultura. Antes de entrarmos nestas definições, vale ressaltar que devemos considerar para definirmos uma noção cientificamente aceitável para Canclini:

a) uma definição unívoca, que situe o termo cultura num sistema teórico determinado e o livre das conotações equívocas da linguagem comum.

b) um protocolo de observação rigoroso, que remeta ao conjunto de fatos, de processos sociais, nos quais o cultural possa registrar-se de modo sistemático (CANCLINI, 2005: 38).

No pensamento antropológico e filosófico, por algum tempo, definiu-se cultura como aquilo que era oposto ao natural. Ou seja, cultura como algo que abarcasse tudo aquilo que foi construído pelo homem em contrapartida a aquilo que era natural, que simplesmente existia no mundo. Entretanto esta explicação se verificou superficial, pois como ela poderia englobar tantos aspectos sociais, econômicos, políticos, religiosos, artísticos e etc. Para Canclini é preciso questionar se isso não seria um sinônimo idealista do conceito de formação social, tal como ocorreu, por exemplo, na obra de Ruth Benedict, segundo a qual a cultura é a forma que adota uma sociedade unificada pelos valores dominantes. (CANCLINI, 2005: 38)

Esta visão de oposição de cultura e natureza ao menos admite que toda criação humana em todas as sociedades é cultural, diferentemente do uso coloquial de cultura apresentado acima, que excluí uma parte desta produção. "A consequência política dessa definição foi o relativismo cultural: admitir que cada cultura tem o direito de dotar-se das suas próprias formas de organização e estilos de vida, mesmo quando incluam aspectos que podem ser surpreendentes, como os sacrifícios humanos ou poligamia" (CANCLINI, 2005: 39). Desta forma extinguimos a ideia de que existem produtos desenvolvidos por humanos ou sociedades que são superiores a outras, e compreendemos tudo como cultura. 
Entretanto quando tratamos de tantos aspectos distintos da vida social em uma mesma noção, ela perde a eficácia operacional.

Para delimitar a cultura de outros aspectos sociais precisamos compreender o que opõe cultura e sociedade. Esta definição aparece e meados do século XX, mas é mais bem definida por Pierre Bourdieu, onde compreendemos a sociedade como conjunto de estruturas que delimitam e distribuem poder e produção entre pessoas em âmbitos sociais, políticos e econômicos. Porém, existem alguns aspectos que não se enquadram dentro destas análises práticas, como por exemplo as variadas línguas e rituais espalhados nas diferentes sociedades.

Para Bourdieu, ao analisarmos o capital cultural é de fundamental importância levarmos em consideração o capital escolar e a origem do social do indivíduo, pois eles são diretamente relacionados. Dentro da análise feita por Bourdieu, com base em sua pesquisa quantitativa, relacionando a frequência a museus ao capital escolar no livro A Distinção - Crítica Social do Julgamento (BOURDIEU 1982: 18), observamos que quanto maior o nível de especialização acadêmico, maior é a frequência de visitação aos museus, bem como o tempo despendido diante de uma obra. E não apenas particularmente no caso das artes plásticas esta estatística se perpetua, mas também em relação a música, a literatura e ao cinema. Enfim, nos segmentos compreendidos como culturais, ou melhor, como a cultura legítima, a relação entre educação e frequência é direta, cujo quanto maior o grau de instrução, maior a procura por este tipo de entretenimento.

Assimilar ou compreender uma noção abstrata, tal como é o caso da noção de arte, significa dominar os códigos estéticos e históricos que circundam este universo, é ter o escopo necessário para diferenciar movimentos artísticos e associá-los ao momento em que foram desenvolvidos. Apenas "ver" as obras, ou frequentar galerias e museus, não é entender seu significado. Analisando brevemente a história fica nítido a relação de cultura e classe social, uma vez que a nobreza não apenas patrocinava a arte como também detinha o conhecimento para compreendê-la. Uma corte frívola, abastada e com tempo ocioso pode se dedicar a estudos de arte, de filosofia e literatura, na qual o acesso ao conhecimento era absoluto. Já a classe trabalhadora possuía apenas sua força de trabalho e precisava dela para subsistir, o tempo ocioso era quase inexistente e o acesso à educação era baixo. Logo ficava claro também que quem determinava o gosto - isso que era tido 
como belo e bom - era a mesma nobreza que desfrutava dele. Segundo Bourdieu, a distinção social concentra-se nas práticas culturais, que podemos classificar por três níveis que expressam aspectos subjetivos do comportamento que definem os "gostos". O primeiro deles é o gosto legítimo, a estética dominante, ou o gosto erudito.

A ideia de gosto legítimo ou erudito dialoga diretamente com as classes economicamente dominantes, que devido as estruturas sociais vigentes possuem maior domínio do capital cultural (artístico) legitimado. É entendido que existe um modo "correto" de se compreender a arte, e ele está ligado a estudos eruditos sobre o campo, que apenas uma pequena parcela da população tem acesso. Desta forma, o gosto legítimo de uma estética dominante é conectado com uma classe social abastada e culta que domina os códigos estéticos e históricos artísticos. Os próprios espaços físicos dos museus são intimidadores e hostis para aqueles que não dominam esses códigos. As pessoas não sabem se podem rir, falar alto, ou conversar animadamente dentro de museus. Supostamente concebidos para oferecerem uma ambiência favorável à apreciação da arte, eles são exclusivos e silenciosos, apesar de darem a impressão de vigilância comportamental àquele que contempla a obra, onde se sentir confortável está ligado a uma segurança interna de domínio intelectual. O próprio espetador não se limita a observar apenas a exposição, mas também a forma de contemplação do outro, afinal, por mais que seja velado, há uma questão de diferenciação social daquele que é de fato legitimado como culto, "cria-se a ilusão que as desigualdades não se devem aquilo que se tem, mas aquilo que se é. A cultura, a arte e a capacidade de desfrutála aparecem como "dons" ou qualidades naturais, não como resultado de uma aprendizagem desigual devido a divisão histórica entre as classes" (CANCLINI, 2004: 81).

Já o segundo nível, a estética dos gostos médios, como já explicita a própria denominação, está em um lugar intermediário entre as artes 'legítimas' e as populares. Ele diferencia-se do gosto dominante pela falta de autonomia no próprio campo, que é submetido a uma indústria cultural, aos donos de empresas e a demandas externas, dentro da lógica de conquista de mercado. Bourdieu ${ }^{22}$ afirma que existem práticas que são características do gosto médio, como por

${ }^{22}$ BOURDIEU, Pierre. Un art moyen: Essai sur les usages sociaux de la photgraphie. Paris: Minuit, 1965. 
exemplo a fotografia, que não é tida como uma arte maior, mas também não é completamente acessível a classes mais baixas. ${ }^{23}$

E por fim, a estética popular ocupa um espaço pragmático e funcionalista, ao contrário da estética da burguesia, ou o lugar social na qual ela se localiza, que se baseia em poder econômico e muito capital cultural, além, evidentemente, do capital social. As preferências estéticas das classes populares estão ligadas a escolha do necessário, seja ele por uma funcionalidade prática ou imposto por uma necessidade social de possuir determinados objetos. O consumo de objetos desta classe baseia-se na função utilitária deles, existindo uma recusa a gratuidade e a futilidade da "arte pela arte". De certo modo isso ocorre também por esta classe não dominar os códigos artísticos para a compreensão e o acesso ao Campo da Arte erudito, desta forma os bens materiais ganham importância quando eles assumem uma função na vida cotidiana, e não para a contemplação puramente. Compreender os tipos de consumo estético das classes nos auxilia a refletir sobre as exibições artísticas e sua legitimação. Torna-se simples o entendimento de que aquilo que é tido como obra de arte, que preenche os espaços de galerias e museus é produzido e consumido majoritariamente por uma elite intelectual e social, que é quem aprova e confecciona o que será entendido como arte e logo como cultural.

Podemos categorizar, segundo Jean Baudrillard, quatro tipos de valores na sociedade que são importantes para compreendermos a diferenciação entre o socioeconômico e o cultural. São eles: a) Valor de Uso: referente a funcionalidade do objeto; b) Valor de Troca: ligado ao preço de mercado ou a custo da hora de trabalho; c) Valor de Signo: representa as conotações simbólicas ligadas ao objeto, como por exemplo o status referente a ele e a quem o possui dentro de uma sociedade; d) Valor de Símbolo: Relaciona-se com objeto específico e situações ligadas a ele. Dentro destes quatro tipos de valor da sociedade podemos destacar os dois primeiros que trata da materialidade do objeto, dos dois últimos que se referem a processos de significação, ou cultura.

\footnotetext{
23 Vale atentar para o fato de que Bourdieu escreveu sobre a fotografia em 1965 (BOURDIEU, P. Un art moyen: Essai sur les usages sociaux de la photgraphie. Paris: Minuit, 1965), hoje com a fotografia digital e principalmente com os smartphones o acesso à fotografia se modificou, bem como o uso que é feito dela, onde antes era majoritariamente material, ou seja, impressa em papel, hoje é em sua maioria virtual.
} 
Com isto chegamos a uma possível definição operacional: "a cultura abarca o conjunto de processos sociais de produção, circulação e consumo da significação na vida social". (CANCLINI, 2005: 41). Atribui-se esta dificuldade em definir cultura por ela ser um processo social e desta forma está sempre se modificando e se apresentando de formas distintas, se transformando, tendo reapropriações ou ressignificações dentro de uma sociedade intercultural. Canclini fala dessa concepção processual e cambiante da cultura dentro do artesanato alegando que a produção artesanal se dá geralmente em áreas rurais ou indígenas, e quando são deslocados para os centros urbanos e consumidores pertencentes a uma realidade muito distinta da dos artesãos se apropriam delas, são atribuídas a essas peças funções diferentes daquelas pensadas na fabricação.

Dentro do artesanato brasileiro por exemplo, as ressignificações dos objetos produzidos nos interiores e trazidos às áreas urbanas geralmente ganham função decorativa. Independentemente se são panelas de barro, cestos, vasos marajoaras, pratos, colheres de pau ornadas e mais uma gama de produtos que originalmente teriam uma função doméstica de uso prático, são convertidos em peças de decoração. No interior do país existe uma vasta produção artesanal que é fundamental para a subsistência de homens e mulheres em locais isolados, à margem da sociedade, que o acesso à educação, à saúde e a recursos hídricos são precários bem como políticas econômicas nestes locais.

A venda desses objetos gera fonte de renda para pequenas cidades que sobrevivem deles ao longo de gerações. O próprio artesão já compreende que o uso original do seu produto será modificado, desfuncionalizado, ressignificado, e desta forma ele próprio adapta a sua produção para atender esta demanda de mercado. E dentro de uma visão antropológica não existe uso mais ou menos legítimo. Existe uma mudança direcionada pelo mercado dentro do padrão original do artesanato. E, para o artesão admitir que ele também se adaptou para impulsionar suas vendas e assim obter mais lucro é algo comum, uma vez que o artesanato não é associado, assim como a arte, a uma criação divina e particular, isto é, algo independente ou autônomo em relação às coisas do mundo ou dos valores sociais que todos empregam, mas como uma fonte de renda a partir de objetos meramente decorativos. O que para nós, não existe diferença, ambos são moldados pelas demandas de mercado.

Precisamos analisar também que a mudança de significação dos objetos 
está ligada diretamente a uma relação de poder, onde existem agentes legitimadores (que muito provavelmente não pertencem a parcela da sociedade que produz artesanato) que determinam formas de uso a esses objetos quando eles estão realocados nos centros consumidores. Novamente existe uma posição elitista e taxativa de poder que determina a produção artesanal e a sua venda no mercado.

Voltando a Canclini, ao prestar atenção nos deslocamentos de função e significado dos objetos no trânsito de uma cultura para outra, necessitamos falar de definições sociossemióticas de cultura, que abarcam o processo de produção, circulação e consumo de significações na vida social. Para ele existem quatro vertentes contemporâneas principais. A primeira é a Cultura como a instância em que cada grupo organiza sua identidade, o que já é debatido desde o século XIX, porém devido a uma visão de mundo mais pautada na globalização, considera-se hoje aspectos referentes a interculturalidade, na qual se analisa globalmente os meios de produção, circulação e consumo, compreendendo assim que as fronteiras étnicas e nacionais podem ser porosas, por mais que tenham repertórios culturais distintos. A segunda é a Cultura Vista como Instancia Simbólica da Produção e Reprodução da Sociedade, que defende que na sociossemiótica, a cultura e a sociedade são fruto do entrelaçamento dos comportamentos sociais, entre o material e o simbólico. Desse modo, a cultura e o social são sobrepostos, e entende-se que em todas as práticas sociais existe uma dimensão cultural, mas que nem tudo é cultura, pois ela não é o mesmo que a sociedade como um todo, em todos os aspectos que a estruturam. A terceira definição, Cultura como uma Instância de Conformação do Consenso e da Hegemonia, diz respeito ao uso da palavra cultura como exercício de poder, que ocorre quando utilizamos o termo para tratar de uma elite. Do mesmo modo, quando tratamos de cultura popular também estamos exercendo uma visão taxativa e hierarquizada em relação a cultura erudita. E por fim, a Cultura como Dramatização Eufemizada dos Conflitos Sociais, se refere a interpretação simbólica a partir do teatro, da música, da dança e outros manifestos artísticos daquilo que está acontecendo na sociedade, mas de forma dramatizada, que expõe os confrontos de forma interpretativa.

Então para entendermos o que se tem como definição de cultura popular, precisamos primeiro descartar as definições funcionalistas, de caráter universal ou estruturalistas, como lógicas mentais, bem como ela também não deve ser vista de forma idealista, como acredita-se que ela expressa as características pessoais de 
um povo, pois isto não se trata de uma definição metafísica e sim das relações sociais. Para Canclini, e tendemos a concordar com suas palavras, as "culturas populares se constituem por um processo de apropriação desigual dos bens econômicos e culturais de uma nação ou etnia por parte dos seus setores subalternos, e pela compreensão, reprodução e transformação, real e simbólica, das condições gerais e específicas do trabalho e da vida”. (CANCLINI, 1983: 43)

Visto isso, podemos compreender que aquele que absorve e participa de manifestações da arte culta ou da popular foi levado a tal ponto a partir da estrutura social que pertence, ou seja, das famílias, das escolas, dos meios de comunicação, das instituições que integram os cotidianos. Pierre Bourdieu denomina esses lugares de instâncias de legitimação e consagração social. O acesso a determinado nível escolar, ou situação econômica, atuam no processo de formação do consumo cultural de cada camada social, bem como a compreensão hegemônica do próprio meio define as noções pessoais de cada indivíduo em relação as definições do que é a cultura erudita e a popular. Na América Latina esse conceito se torna um tanto complexo pois temos uma formação cultural mista, na qual importamos noções do modelo universal da arte, baseado na formação artística europeia e estadunidense e temos também a forte manifestação da arte indígena e mestiça em todo continente. A partir desses processos de cruzamento entre as duas culturas artísticas e estéticas, temos uma expressão mista e culturas, um cruzamento entre elas que se dá de forma comum nos lares e no imaginário simbólico coletivo. 


\section{As Relações Fronteiriças na Produção de Objetos - 0 Design, a Arte e o Artesanato como Elementos de Comparação}

À primeira vista, para tratar de objetos da cultura material, produzidos em uma sociedade industrial, devemos considerar que esse tipo de abordagem pode nos remeter a uma análise dos bens de consumo produzidos em larga escala pela indústria e que são adquiridos em lojas de departamentos. Essas lojas empregam sofisticados meios de convencimento da pseudo importância e legitimidade desses objetos, afinal eles são apenas objetos com valor de troca simbólica ou comercial e sem qualquer valor de uso social. Esses mecanismos de marketing, não ocorrem apenas nesses estabelecimentos, mas são empregados antes, durante e depois da compra. Fora isso, os objetos podem se distinguir em uma grande variedade de classificações que muitas vezes, devido a conceitos hegemônicos presentes em nossa sociedade, esquecemos que eles fazem parte de um regime operativo de circulação de mercadorias para consecução da mais valia, como é o caso dos objetos que chamamos de obras de arte, das peças de artesanato e de objetos de design. Por exemplo: uma pintura de Scliar, uma peça de cerâmica de Mestre Vitalino e uma cadeira Thonet. A similaridade simbólica entre os três está no fato de que são compreendidos socialmente como objetos diferenciados daqueles que possuem um valor de uso doméstico e funcional. Esses objetos são socialmente hierarquizados em uma escala de valores simbólicos onde eles possuem um status mais elevado, e porque são tidos como resultado de um processo criativo no qual seu autor também se difere socialmente como artista, artesão ou designer, e carregam, portanto, a imagem de gênio. Se no capítulo anterior traçamos uma análise com ênfase nos produtores, agora vamos nos debruçar mais na análise dos objetos em si.

Apesar dessas três categorias profissionais ocuparem um mesmo lugar social, isto é, um lugar ideal de produtores de objetos superiores em relação aos demais objetos da cultura material, cada um se integra a um espaço distinto de produção, circulação e recepção, bem como possuem seus próprios valores simbólicos, econômicos e sociais. Para compreendermos estas diferenciações, 
precisamos primeiramente compreender as questões políticas e culturais por trás destas classificações de objetos e quem as produz e em que locais eles são exibidos, vendidos ou trocados. Poderíamos afirmar sem erro que o entendimento das pessoas, incluindo aí o entendimento dos agentes de produção dessas três categorias opera quase sempre de forma superficial, isto é, com considerações acríticas e passadistas. Quase que na totalidade das afirmações pronunciadas a torto e a direito pelos pares ou pelas pessoas comuns, a obra de arte é sempre vista como um canal que nos auxilia a entrar em contato com emoções estéticas e espirituais, a peça de artesanato constantemente se apresenta como a presença da tradição popular e primitiva e o objeto de design como a expressão da funcionalidade perfeita conectado a uma forma anatômica ou ergonômica.

Entretanto, sustentamos que estas três categorias classificatórias não possuem nenhuma validade além dos interesses mercantis que lhes são atribuídas, pois os objetos são compreendidos desta forma apenas quando os deslocamos do mundo "real" 24 , isto é, quando os colocamos em lugares especiais de circulação para realizarem seus papéis sociais com valor de troca simbólica e eventualmente quando esse valor é invertido em valor financeiro. Ou seja, quando postos à venda em dependências comerciais dentro desses lugares de legitimação, tal como nos museus e suas lojinhas de bugigangas "artísticas", ou então quando os analisamos separadamente do convívio dos outros objetos, sejam eles materiais ou tidos como espirituais. Esse tipo de comportamento de considerar os objetos industriais, artesanais ou artísticos apenas pelo seu valor de troca simbólica como se possuísse um valor de uso social, nos parece ser um equívoco, pois precisamos considerar o contexto social vivo ou "real" para entendermos de fato qual é a representação simbólica concreta de cada um deles.

Como análise inicial podemos agrupar esses objetos tal como Pierre Bourdieu o realizou: como pertencentes à cultura legítima ou erudita ou pertencentes à cultura popular, lembrando que esses lugares são transitórios e circulares, ora objetos cultos, ora objetos populares. Assim um objeto da cultura erudita pode ser popularizado ou um objeto popular pode ser considerado erudito,

\footnotetext{
${ }^{24}$ O termo "real" entre aspas é para distinguir o mundo concreto das relações humanas e o mundo imaginado ou construído arbitrariamente pelos grupos sociais. Essa separação é muito complicada conceitualmente, afinal podemos nos perguntar sob quais critérios temos para distinguir isso que é real disso que é imaginado? Para todos os efeitos, a separação aqui é apenas didática, daí não nos aprofundaremos.
} 
por exemplo: uma sonata de Chopin interpretada com ruídos coletados das ruas, buzinas dos carros, descarga de caminhões, sinais sonoros de entrada de garagens, apitos de guardas etc., e os caracteres gráficos do Profeta Gentileza, que saíram dos muros e colunas dos viadutos e passaram a ser caracteres "cults", especialmente na produção de discos de cantores e músicos populares com aspiração a se distinguirem dos cantores e músicos "pseudos sertanejos" ou "bregas". Essa variação ocorre mediante a processos de legitimação impostos pelos agentes de circulação que são poderosamente influenciadores, afinal eles nos ditam a quem e qual espaço pertence cada manifestação cultural e desta forma a sua produção de objetos. Obviamente a presença desses agentes de legitimação é responsável desta distinção e torna possível o mapeamento geográfico e econômico de produtos diferentes e assim podemos traçar perfis tanto de consumidores como de desenvolvedores (produtores), o que nos faz entender os espaços de venda e apreciação de objetos de design, artesanais e de arte.

\section{1}

\section{As Intercessões e Dissemelhanças Simbólicas dos Objetos Industriais, das Peças de Artesanato e das Obras de Arte}

A noção de objeto - aquilo que não é sujeito ou que não se confunde com ele - pode à primeira vista parecer universal e se aplicar a qualquer categoria de artefatos produzidos artificialmente. Utilizamos o substantivo objeto para nos referirmos a quase todos os tipos de itens como uma palavra neutra para designar algo fisicamente palpável. Entretanto, categorizar os objetos e compreender as diferenças simbólicas entre eles requer um debate acerca das noções de forma e função e como socialmente as que aplicamos dentro do universo do design, do artesanato e da arte.

Um primeiro ponto de análise muito superficial é a diferenciação linguística básica que usamos para tratar cada um. Os objetos de artesanato nomeamos de peças, os de arte de obras e os industriais de objetos. A diferenciação entre os três não está apenas no nome, mas em todo o universo de produção, regras fixadas pelos agentes de legitimação para a circulação, para exibição e venda destes objetos, bem como para consagrar o seu status social 
também está vinculado ao nome que carrega. Apesar de parecer simples a fronteira que separa as três categorias, ela é complexa e porosa, e é necessária uma análise detalhada para tal separação em determinadas circunstâncias. Podemos compreender os três também, tal como Marx estabeleceu a conexão, como produtos, isto é, que pertencem a uma mesma natureza alienada de seu eventual propósito inicial, a mercadoria. São artefatos feitos para serem trocados por dinheiro, enfim, de objetos que não são concebidos ou pensados tendo como fim último o uso, mas a troca. Contudo, aplicar esta compreensão às obras de arte nos parece mais estranho do que quando nos referimos a um objeto de design, por exemplo, e isso está conectado as diferentes ideias ou noções prévias que temos de cada uma dessas categorias que aplicamos aos objetos, bem como de quem as produz. Como vimos, as obras de arte, de acordo com as noções românticas não servem para isso ou aquilo. Além da fruição estética, do prazer sensível que oferecem gratuitamente, bastam-se a si mesmas e a sua troca por dinheiro é vista como uma aberração, uma coisa eventual pois quem compra obras, o faz por "amor à arte". ${ }^{25}$ E o objeto de design? Não é uma coisa gratuita, sem para isso ou aquilo, mas algo que foi realizado para ser usado socialmente, daí pode ser considerado como produto ou mercadoria. Mas teríamos aí esgotado a nossa discussão?

Julgamos que um primeiro ponto a se observar é que ocorrem dois grandes equívocos na análise dos objetos. O primeiro deles é tentar entendê-los de forma deslocada de seu contexto social, isto é, levarmos a análise para observação formal e estética e ignorar aonde, quando, e em que contexto social eles foram produzidos. Isso torna a observação inexpressiva e dá margem a gerarmos conceitos taxativos e superficiais, tal como os filósofos antigos definiam a ontologia das coisas por conta de suas essências. Outro ponto de lapso se dá quando a biografia daquele que produziu objeto se torna mais importante do que sua produção, onde a análise é feita a partir do produtor e não do meio, e quando compreendemos que os objetos se criam a partir de contextos sociais fica claro que a produção nunca é de caráter individual. Quando defendemos a prática de relacionar o objeto apenas ao seu criador, também estamos legitimando a ideia de

25 BOURDIEU, Pierre et DARBEL, Pierre en collaboration avec Dominique Schnapper. L'Amour de l'art. Les musées d'art européens et leur public. Paris, Les Éditons de Minuit, 1966. 
gênio criativo e individual e desconsiderando que toda forma de trabalho é coletiva. Quando compreendemos o contexto sócio cultural em que as peças de artesanato, os objetos de design ou das obras de arte foram produzidos, podemos entender também aspectos relativos a esta sociedade e o mercado que opera com esses objetos. A observação dos objetos deslocados do mundo e conectados apenas com quem os desenvolveu acaba por gerar uma noção errônea dos mesmos tal como ocorre com aqueles que colocamos no rol dos pertencentes ao estatuto tradicional da obra de arte.

Com base na análise histórica do surgimento da ideia do artista como gênio criativo e da apropriação desta noção para o artesanato e o design, podemos nos questionar se de fato este adjetivo de criador tem o mesmo peso para cada profissional, independentemente de concordarmos com ele ou não. Conforme explicamos mais acima, este termo está inserido dentro de uma concepção popular ou senso comum que é reproduzido sem discussão crítica há séculos, e como isto altera a percepção do objeto que cada uma dessas categorias profissionais o desenvolve.

Os objetos entendidos como obras de arte têm como "finalidade" levar o observador para um lugar de contemplação ou de profunda aplicação da mente em abstrações. Esse estado meditativo não é um mal em si mesmo, mas obviamente isto se torna uma meia verdade se tratarmos do objeto deslocado das outras coisas do mundo e do "artista" que o produziu, desprezando seu contexto histórico. Entender o objeto desta forma é o que é desejado ao espectador que frequenta um museu, ou melhor, esse é o comportamento social esperado de quem sai de casa para ir a tal lugar, a análise pela contemplação estética apenas, sem maiores questionamentos. Tício Escobar em seu livro, El Mito del Arte y el Mito del Pueblo, defende que o que aceitamos, o que nos foi imposto, como o modelo universal da arte, foi aquilo que foi produzido na Europa entre os séculos XVI ao XX. Desse modo, o que é proposto como arte hoje é um conjunto de práticas que trazem referência dessa noção de arte, aliada à noção da produção de objetos únicos e que não podem ser repetidos. Essas obras têm como finalidade expressar o gênio individual, sendo este o indivíduo capaz de produzir formas estéticas diferenciadas de outras formas culturais e livre de funções utilitárias que obscureceriam sua percepção clara. (ESCOBAR 2014, 40).

Podemos levar a discussão acerca dos objetos para as diferenciações 
estéticas e simbólicas de forma e função. $\mathrm{O}$ debate sobre a arte, a produção industrial e a artesanal teve início na Europa no século XIX, a partir das mudanças nos meios de produção de manufatura, onde parte do sistema artesanal de produção foi substituída pela produção industrial e o desenvolvimento tecnológico. Em consequência disto, a divisão entre forma e função se tornou mais nítida e inaugurou questionamentos acerca da valorização da produção artesanal e das artes decorativas, uma vez que grande parte dos objetos funcionais passavam a ser produzidos industrialmente, muitas das peças artesanais ganhavam o caráter de "decorativas". A separação entre o artista e o artesão e mais tarde do designer, é também a divisão entre as Artes Livres e as Artes Aplicadas, na qual a primeira se relacionava com as obras desenvolvidas por artistas, com apelo estético e contemplativo e a segunda com os objetos artesanais decorativos ou industriais funcionais. Ao mencionar função social dos objetos produzidos, nos remetemos de forma rápida à função utilitária, prática ou técnica, entretanto existem funções complexas de caráter sócio cultural e de conotação simbólica, como objetos artesanais produzidos por indígenas, por exemplo.

Segundo Tício Escobar, quando falamos de forma e função podemos tratar de três modalidades de objetos: "Os belos (várias funções do mesmo valor); os expressivos (uma função fundamental hegemônica) e os ornamentais (uma função secundária). Qualquer um destes objetos pode ter um caráter estético, diz a estética industrial, mas só se torna artístico quando um significado poético é acoplado; isto é, quando o dito objeto é capaz de provocar um choque revelador, o surgimento de uma nova realidade" (ESCOBAR, 2014: 69). “A artiscialidade não se mede pela falta de funções, mas pela possibilidade de que as formas passem a causar esse choque desencadeador de novos significados que constitui o efeito artístico fundamental" (ESCOBAR, 2014: 67). Ocorre que essa noção é filosófica, digamos assim. Trata os objetos como se possuíssem essências, características únicas e fixas que podemos empregar para classificar todos os objetos que se assemelham a cada uma dessas categorias. Como não estamos mais no tempo de Aristóteles, nem tampouco de Kant, há que considerarmos outra situação mais afeita aos nossos tempos.

O fato da noção romântica ou idealista oferecer aos objetos a sua gratuidade ou ausência de finalidade, exceto a estética, de o objeto não possuir função utilitária prática ou concreta para o uso social, também não o coloca 
necessariamente no estatuto artístico. Apesar de a não função ser requerida pelo idealismo estético, eles não ocupam o lugar de obra de arte, pois existem processos de legitimação que são fundamentais para se definir que objetos são artísticos ou não. Esses processos legitimadores, que mais têm a ver com aspectos mercadológicos e políticos do que estéticos, defendem que o objeto de arte deve produzir sentido por conta própria, isto é, deve gerar reflexão, ou emoção, ou contemplação ao observador. Porém sabemos que isso está dentro do grande conjunto de noções hegemônicas que o mito do gênio criador também pertence, embora não seja um fato, mas ainda é uma romantização do Campo da Arte. O produto artesanal por exemplo, pode ser funcional ou não, e o fato de não ser utilitário pertence a este espaço onde não se pode categorizá-lo como obra de arte, e é compreendido como arte decorativa. Já o produto industrial em geral possui funcionalidade, mas também não se exclui o fator estético do objeto.

Dentro do Campo do Design por exemplo, é recorrente que as análises teóricas desenvolvidas dentro do campo se deem forma superficial. Queremos dizer com isso que a prática de analisar o objeto de forma deslocada da sociedade e situando o designer como uma espécie de criador independente do mercado comercial é uma falácia, pois embora haja um esforço dos pares para produzir um convencimento contrário, o designer não é um profissional autônomo tal como o artista. Os pares do campo usam a dita metodologia projetual para justificar a legitimidade da profissão e a sua importância em um contexto social, e não necessariamente do pensamento e da pesquisa acerca das atribuições sociais do designer. Entende-se o design, especialmente por aqueles que pertencem ao campo, como uma prática que tem por finalidade beneficiar a população e desta forma o objeto industrial desenvolvido por um designer é entendido como carismático, uma espécie de bondade ou caridade para com os infelizes mortais. Podemos analisar a partir do livro Design como Prática de Projeto de Gui Bonsiepe, como se dá o pensamento hegemônico do Campo do Design e assim como o objeto é compreendido dentro e fora dele. $\mathrm{O}$ autor afirma que o design industrial não pode ser transmitido em por uma instituição de ensino que promova um curso de projeto em design, uma vez que o saber essencial do design industrial não é sistematizado ou formalizado, desse modo não está nos livros. Bonsiepe ainda prossegue seu discurso defendendo que o design não é uma disciplina da estética aplicada, mas que é uma ferramenta usada para satisfazer necessidades 
materiais e psicológicas da população (Bonsiepe, 2012: 47, 85).

Quando se admite que um saber profissional não é transmissível a partir do conhecimento gerado dentro de uma instituição de ensino, subentende-se que o profissional atuante chega ao conhecimento de uma forma que poderíamos chamar de obscura, tal como ocorre nas hagiografias sobre epifanias dos santos ${ }^{26}$ ou nas anedotas ${ }^{27}$ contadas sobre os artistas, que ambos são dotados de um dom divino e criativo. No Campo do Design, acredita-se que a prática do designer se dá apenas de forma assistemática aplicando algo não muito claro e distinto, que é apresentado sem discussão, a metodologia de projeto. E que ela é aplicável apenas por alguns iniciados, dentro de um mercado de trabalho muito específico e que não pode ser aprendida objetivamente por conta de forma teórica e defendida de modo claro e distinto. A coisa simplesmente se dá com a aplicação da metodologia projetual. Esta visão romântica do design acaba por desmerecer a própria classe profissional, e deslegitimar a profissão, aparentando não haver cientificismo no campo, apenas o domínio de aspectos técnicos impenetráveis ao cidadão comum.

Deste modo, quando tratamos o designer como criador autônomo e absoluto, dotado de uma criatividade que não é bem esclarecida, que elabora projetos por conta própria e visando melhorar a qualidade de vida da sociedade, terminamos por associar, o projeto e a fabricação do objeto industrial a noção de criador único, tal qual à forma equivocada de como tratamos a arte e seus criadores, isto é, uma forma idealista ou romântica. Analisando o design de uma garrafa térmica, por exemplo, a partir de características formais e estéticas e por quem a desenhou. Caso esse designer tenha reconhecimento, esse objeto é visto de forma carismática e se equipara simbolicamente a uma obra de arte ou uma peça decorativa, pois certamente será exibido dentro das casas com igual holofote. Como exemplo citarei o espremedor de laranjas de Philippe Starck, que sem dúvidas é emblemático dentro da discussão acerca da fragilidade das fronteiras entre o valor de uso e o valor de troca simbólica dos objetos domésticos. De certo que esse espremedor de laranjas tem um valor de troca simbólica muito superior ao seu valor de uso. Primeiro porque em sua função básica, de espremer laranjas, é ineficaz, ele não é funcional, nem mesmo em termos básicos, que seriam

\footnotetext{
26 VARAZZE, Jacopo de. Legenda Áurea. São Paulo: Companhia das Letras, 2003.

$27 \mathrm{Na}$ verdade, nos referimos aqui às biografias de artistas, mas que são narradas de forma anedótica por VASARI, Giorgio. Vida dos artistas. São Paulo: Editora WMF Martins Fontes, 2011.
} 
espremer a laranja e fazer com que o suco flua até um recipiente sem sujar a mesa aonde ele está. Assim, se do ponto de vista de sua funcionalidade não é isso que ocorre, pois, o sumo da laranja se esparrama para fora do copo, contudo alguns pares do campo, o defendem, pois esse espremedor possui um design arrojado, inovador e digno, tal como um objeto de arte e, além disso, é assinado nada mais nada menos do que pelo carismático designer Phillipe Starck. Enfim, apesar desse espremedor de laranjas em termos funcionais ser claramente inferior a um espremedor convencional e que pode ser adquirido em lojas de um e noventa e nove, em termos simbólicos ele se insere em outro "posicionamento", tal como os profissionais de marketing gostam de dizer. Ele é compreendido como um objeto de design, que está diretamente refletido em seu valor monetário e assim a seu valor "agregado", outro termo bastante apreciado e empregado pelos "marqueteiros".

Porém, uma análise feita unicamente a partir desta ótica, que classifica o objeto por seus valores estéticos (valores esses que são inculcados ou condicionados socialmente para as pessoas através da propaganda e propagação sistemática de noções que julgamos passadistas, pois de modo geral as pessoas consideram que é belo aquilo que somos levamos a acreditar que é, ou em outras palavras, aquilo que é legitimado como tal) e por seu 'criador", é extremamente superficial, isto é, fora dessas convenções tradicionais, não resiste a uma argumentação contrária, mínima que seja. O que ocorre é que os pares e depois a própria sociedade são vítimas induzidas a essas noções, tanto pelos teóricos do campo como pelos profissionais do mercado industrial que citávamos acima (marqueteiros), pois esse tipo de visão é favorável a ambos. 


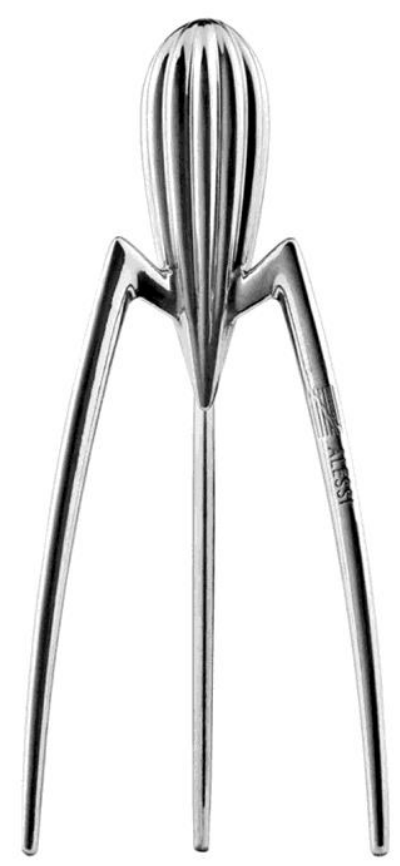

Figura 2 - Juice Salif. O icônico espremedor de laranja manual do designer Philippe Starck é feito de alumínio e possui uma forma bastante distinta da maioria dos espremedores de laranja convencionais, entretanto sua funcionalidade é amplamente questionada entre os pares do campo. (Fonte: Juice Salif, Phillipe Starck - Espremedor de laranjas desenvolvido pelo designer Felipe Starck: https://casaclaudia.abril.com.br/blog/design-de-origem/muito-alem-de-um-espremedor/. Acesso em 20/10/2018).

Sustentamos que dentro do que defendemos ser uma análise a partir da produção social do design, se estabeleça uma observação que não seja puramente um juízo de valor estético do objeto ou de valor moral para com o designer criador. Tal como afirmamos no início, da Academia à cultura popular, isso que é o "objeto de design", é tratado geralmente como um objeto à parte da sociedade, isto é, algo autônomo ou independente dos outros objetos empregados pela sociedade, como se fosse algo diferente e que não faz parte ativa da nossa história e da nossa vida social, enfim, algo em si mesmo que parece deslocado das outras questões do mundo, e pensado num ato espontâneo de iluminação criativa.

Dentro de uma noção hegemônica, o objeto não é visto como resultado de uma demanda da sociedade e tempo em que foram produzidos, mas algo dotado de uma natureza espiritual, colocado com um status que se equipara a de uma obra de arte, tal como os idealistas românticos consideravam tais objetos. Essa noção nos parece ser um grande equívoco. Através do livro Objetos de Desejo de Adrian Forty podemos exemplificar como história dos objetos é completamente ligada a 
história social dos homens e mulheres. Quando tratamos de objetos nos dias de hoje, isto é, desde a Revolução Industrial, não podemos desvencilhá-lo do fato de que a sua situação histórica concreta na sociedade industrial é a de que são produtos, isto é, mercadorias para produção da mais valia. Existe potencialmente em todos os objetos industriais um valor de troca monetária, e a sua fabricação ou o seu desenvolvimento sempre se deu visando um lucro para aqueles que são os donos das indústrias que o fabricam.

Ao tecermos considerações acerca do consumo de bens materiais e os lucros que envolvem sua produção e venda, podemos falar de dois aspectos diferentes. O primeiro é relativo à indústria em si mesma, e como dentro dela é visto a produção de objetos, no qual o dono da indústria realiza a gerência do seu negócio e de acordo com a ideologia comercial, que não apenas define a produção, mas a demanda dos objetos industriais, enfim aquilo que é produzido a partir de uma intenção de rentabilidade de cada produto pode trazer ao dono da indústria. Verifica-se também que o dono da indústria é responsável pela gestão dos seus funcionários, isto é, a maneira como eles trabalham.

Entretanto, muitos se esquecem que essa gestão é determinada também pela produção de mais valia. Dentro do modo de produção capitalista, afinal de contas, o controle ou a exploração das horas de trabalho é onde o dono da indústria obtém o lucro, pois é justamente pela exploração das horas de trabalho do empregado e não com o preço final da mercadoria, tal como defende Marx, que se dá a produção de mais valia. Então confirma-se que a situação histórica concreta do objeto industrial está diretamente ligada ao modo de produção industrial ou ao capitalismo. Quanto à prática do design e a produção dos objetos industriais, apesar de na maioria das vezes não enxergarmos este tipo de conexão que existe dentro da nossa prática profissional, os objetos industriais, ou as mercadorias, existem para atender à indústria e não ao usuário. Sustentamos que isto se dá porque existe uma visão romântica da prática do design, como foi tratado anteriormente, mas que na verdade precisamos defender que ela se pauta como forma de trabalho, assim como qualquer outra forma de trabalho da sociedade industrial. Nossa profissão soluciona problemas para a indústria, isto é, o problema da indústria é produzir a mais valia e não atender às pessoas, o uso social dos objetos industriais. Assim o designer industrial soluciona os problemas da indústria e não para aqueles que consomem os produtos que desenhamos. De modo 
que sustentamos que é isso que deve ser usado como a definição disso que é o design. Gostaríamos de atentar que para nós isto não se enquadra a todo tipo de produção do design, afinal existe uma parcela de profissionais do campo que trabalha sem o vínculo direto com a indústria, atuando de forma autônoma ou em pequenas empresas. Desse modo, não necessariamente a produção é feita de forma industrial, muitas vezes em escalas de produção menores a fabricação de objetos se dá de forma semi-industrial ou manufaturada. Desse modo, as relações de hierarquia interna na empresa e a produção de mais valia podem se dar de forma mais distinta que em uma indústria. Porém, o que vamos tratar aqui, são dos profissionais que trabalham com a produção de objetos seriados industrialmente, afinal em termos quantitativos, os produtos industriais mecanizados ainda são maioria na nossa sociedade.

Para defender esta argumentação, analisaremos alguns dados do livro Objetos de Desejo de Adrian Forty, para usar como base para nossa argumentação acerca do trabalho do designer industrial. De início, vale tratar das considerações do autor sobre das mudanças ocorridas com mobiliários específicos ao longo da história, como forma de exemplificar como essas mudanças se relacionam muito mais com as demandas econômicas da sociedade do que com o "bem-estar" do usuário. As escrivaninhas de escritório são um exemplo dessas alterações. Surgidas na década de 1880, suas adaptações até a década de 1910 se deram à medida em que a escrita cursiva foi fundamentalmente trocada pelas máquinas de escrever, desse modo as escrivaninhas passaram a ter altura ajustável com gavetas redesenhadas. Por mais que as mudanças estruturais pareçam inofensivas e visando o "bem-estar", elas foram realizadas com intuito de reduzir o tempo que a datilógrafa gastava realizando operações técnicas necessárias, tornando-se assim mais produtiva na mesma carga horária de trabalho, portanto tratava-se de exploração do trabalho pelas horas despendidas, mais trabalho pelo mesmo número de horas, um exemplo clássico de apropriação do capital. Do mesmo modo, as cadeiras para datilografia, que foram pensadas apenas no início dos anos de 1920, tiveram origem a partir de estudos desenvolvidos nas fábricas, sobre postura ao sentar (FORTY, 2007: 183-184).

Adrian Forty nos traz também mais informações sobre as mudanças ocorridas no mobiliário de escritório, mas ao fim e ao cabo convergem para a produção da mais valia. A priori ele apresenta a sociologia do trabalho no início do 
século XIX, que é fundamental para entendermos as mudanças de forma de seu mobiliário específico. Os gabinetes de trabalho de um escriturário neste período, por exemplo, permitiam certa privacidade no ambiente do escritório, o que estava diretamente relacionado a autonomia que este funcionário possuía dentro da empresa, no qual os escriturários de categoria superior envolviam-se em toda a sequência do trabalho e por isso eram comparados aos artesãos antes da divisão do trabalho.

No final do século XIX, começam a ocorrer mudanças na forma de organização do trabalho dentro dos escritórios, o que afeta diretamente a função e a forma do seu mobiliário, portanto não se trata de atendimento ao "usuário", de construir postos de trabalho ergonômicos para assegurar a saúde do trabalhador, mas há qualquer coisa que passa desapercebido para muitos pesquisadores. Apesar do escriturário e o operário de fábrica sempre terem ocupado a mesma classe social e terem uma renda mensal muito semelhante, o escriturário possuía um status social mais elevado se comparado ao trabalhador da indústria. Contudo, a demanda por serviços de escritório aumentou rapidamente, o que levou a uma contratação de mais escriturários em relação a gerência e assim também ocorreu uma mudança na forma de trabalho. Onde ainda existia certa autonomia dos funcionários dentro da empresa, passaram a aplicar a mesma setorização das fábricas, o que tornou o trabalho em escritório muito semelhante a uma linha de produção. Cada funcionário passou a ser responsável por apenas uma parte do processo de trabalho que se subdividia em setores específicos. Para atender esta nova demanda de produção o espaço físico também se modificou, acabaram por exemplo, os gabinetes de trabalho com certa privacidade e escrivaninhas abertas também foram adotadas.

Estas mudanças tinham como finalidade otimizar o tempo de trabalho e aumentar a exploração sobre a produção dos funcionários, o que foi nomeado como Administração Científica, que nada mais é do que o estudo feito para entender que mudanças espaciais seriam necessárias para que a produtividade dos escriturários aumentasse no mesmo espaço de tempo de trabalho e claro, com os mesmos salários. Percebeu-se que adotar a mesma setorização empregadas nas fábricas e padronizar as funções dos escriturários assim como o que foi feito aos operários seria mais vantajoso financeiramente para os donos das empresas.

Entretanto, voltamos a ressaltar que as mudanças que ocorreram no 
desenho de mobiliário de escritório e que se deram a partir deste novo procedimento de natureza capitalista que visava exclusivamente a mais valia, não são expostos desta forma pela maioria dos pares do Campo do Design, e sim são edulcorados como "inovações estéticas" e funcionais pensadas para favorecer o "usuário" do produto, no caso, os escriturários.

As novas escrivaninhas, o início do estudo da ergonomia como ciência e a setorização do trabalho, tiveram como finalidade real aumentar a produção do escriturário sem aumentar seu salário e seu tempo de trabalho, contudo ainda mantendo o status de um trabalhador de escritório e não um operário. "Otimizar" a produção foi o "problema" que o designer precisou resolver, e não melhorar as condições físicas do escriturário, apesar de uma coisa afetar a outra é necessário compreender que a razão inicial das mudanças ocorridas, certamente não foi o bem-estar do usuário, e sim o lucro final do dono da indústria ou empresas, que se baseia na relação da produção com as horas de trabalho, o que não difere do trabalho do operário na fábrica. Em suma, as mudanças no design ocorridas no mobiliário do escritório se dão principalmente pela busca da maior eficiência na exploração do trabalho do funcionário.

Outro exemplo, também do livro Objetos de Desejo e que discute a questão política e social dentro do design foi o surgimento da eletricidade e dos eletrodomésticos, produtos industriais praticamente inexistentes até então. Forty relaciona o desenvolvimento dos eletrodomésticos com uma lei vigente no início do século $\mathrm{XX}$ na Inglaterra, que tornava ilegal a exportação municipal de eletricidade, em uma época em que seu uso se limitava à iluminação de ruas, prédios públicos, comerciais e residências. Porém a capacidade de produção de energia municipal era excedente em relação ao consumo, então entre os anos de 1905 e 1914, engenheiros passaram a dar especial atenção ao desenvolvimento de produtos movidos a energia elétrica, o que inicialmente teve maior concentração em objetos domésticos destinados as donas de casa. Ou seja, produção excessiva de energia elétrica estava impossibilitando todo o aproveitamento lucrativo dos donos das industriais, foi criado um mercado totalmente novo que justificasse essa produção e aumentasse exponencialmente o uso da eletricidade no cotidiano (FORTY, 2007: 253).

Voltamos a citar Adrian Forty querendo exemplificar a ideia das inovações do design como ações primeiramente políticas e econômicas, antes do que se 
acredita como processos meramente criativos desenvolvidos tal como os artistas, por pessoas dotadas de uma natureza especial, a desenhá-los e torná-los objetos "especiais" que têm como o objetivo inocente ou uma despretensiosa intenção de solucionar problemas na vida de homens e mulheres. A criação, concepção ou projetos de eletrodomésticos, por exemplo, leva para a vida cotidiana o uso da eletricidade em inúmeras funções, e não apenas para a iluminação. Fogões, geladeiras, cafeteiras, ferros de passar, aquecedores e mais uma gama imensa de produtos invade as casas inglesas no século XX, e passa a justificar a produção de energia. Contudo, para que isso ocorresse foi necessário também a mudança nos hábitos da sociedade, lugar que o marketing, técnicas mercantis de venda, atuou para que a venda desses "novos" produtos se materializasse. A ideia de que os eletrodomésticos otimizavam o tempo das donas de casa, de que eles eram o progresso e o futuro dentro das casas e as mulheres munidas destes objetos para cuidar do lar passavam a pertencer a outro status social e não mais simples "donas de casa", foram essenciais para a venda de produtos elétricos e com isso para aumentar a venda de energia.

Mais uma vez questionamos até que ponto a prática do design tem como principal função "solucionar problemas" e melhorar a vida de seus usuários? Compreendemos que essas inovações geralmente não partem da vontade ou das ideias unicamente do designer. Na verdade, são ações políticas e econômicas dentro da sociedade capitalista industrial. Desse modo vale questionarmos qual a real e principal finalidade do que é isso que é design. Defendemos que a demanda surge de fatores econômicos mais amplos que antecedem os fatores sociais que se dizem preocupados com os consumidores finais. $\mathrm{Na}$ verdade, o que existe são os interesses dos donos das indústrias para gerar mais valia a partir da venda de mercadorias, e são eles que criam as necessidades sociais que o designer irá desenhar. Assim, os objetos elétricos, por exemplo, surgem da necessidade de se vender energia, bem como a ergonomia surge da necessidade de aumentar a eficácia do operário e não para resolver um problema do usuário.

Para nós, para definirmos com clareza e distinção o que é isso que é o design precisamos primeiro perder a visão romântica de que o design é uma prática ligada a um pensamento artístico, que se encontra no plano da criatividade, oriunda da produção do gênio criador e da expressão individual. 
Segundo analisa Iraldo Matias, em sua pesquisa ${ }^{28}$ no departamento de sociologia da Unicamp em 2014, economistas neozelandeses desenvolveram para o Fórum Econômico Mundial um relatório sobre a Competitividade Global, que relacionada à competitividade econômica com o desenvolvimento do design em diferentes países, esclarece a relação paralela entre os dois. Para nós, latinoamericanos, a relação com a preocupação efetiva com o design de produtos ainda é um tanto distante, afinal tal qual afirma Gui Bonsiepe, cabe aos países periféricos do capitalismo como papel principal no mercado industrial mundial, o de fornecer a matéria-prima para que os países de primeiro mundo, e mais industrializados, se encarreguem do desenvolvimento tecnológico e a fabricação dos produtos, além de controlar a distribuição nos mercados internacionais.

Mas tudo isso seria um equívoco se afirmarmos que o nosso pouco conhecimento na área do design se dá pelo nosso distanciamento sul-americano com o desenvolvimento massivo de projetos de design, e crermos que o conhecimento teórico é fruto do investimento tecnológico e de desenvolvimento industrial na produção de bens de consumo. De fato, a crença no design como uma disciplina de desenvolvimento técnico é muitas vezes defendida pelos pares, e o não entendimento da teoria social do design e dos fundamentos históricos elementares fazem que se defenda a não existência de uma ciência do campo.

Voltaremos a citar o alemão Gui Bonsiepe ${ }^{29}$, que é conceituado como um grande expoente da literatura sobre design, para sustentarmos que os próprios pares não defendem que se pense sobre o design, e que acreditam que o domínio dos aspectos técnicos já é suficiente para se debater o campo. Bonsiepe afirma que o design industrial não é uma ciência, nem mesmo uma ciência inexata e que não se tem a produção de conhecimento teórico como objetivo, afirmando que a elaboração de produtos que satisfaçam as necessidades sociais e contenham valor estético são os objetivos de fato do design, além de defender que o design trata de satisfazer as necessidades materiais e psicológicas das pessoas.

A afirmação de Gui Bonsiepe nos parece extremamente similar com o que se acredita no Brasil em relação a produção do design, além de nos auxiliar na compreensão da razão pela qual não sabemos definir o que é design, e o que se

${ }^{28}$ MATIAS, Iraldo. Projeto Revolução; Do Fetichismo a Gestão, uma Crítica a Teoria do Design. 1 Edição. Florianópolis: Editora em Debate, 2014.

29 Nos detemos aqui em trabalhar com o livro Design como Prática de Projeto de Gui Bonsiepe (2012). Deste modo quando tratamos das considerações do autor estamos nos referindo a este livro. 
espera do designer quando se é aluno em uma universidade que prepara os quadros profissionais dessa categoria. Quando não problematizamos socialmente a produção industrial de objetos, acabamos por crer na convicção errônea de que o design "satisfaz necessidades humanas", que é "algo criado para ajudar as pessoas". Não é incomum escutarmos essas afirmações de professores design que posteriormente transmitem para os alunos. A profissão que eles almejam futuramente exercer é socialmente útil e que eles podem solucionar problemas sociais com a prática do design. Não desejamos aqui debater se determinados objetos podem ou não solucionar problemas sociais específicos, nossa problematização vai além. Quando nos atemos apenas ao objeto em si, e seus aspectos técnicos, tecnológicos ou estéticos, acabamos por utilizar de uma argumentação que trata o produto desenvolvido pelo designer como eixo central de uma discussão teórica. Se uma cadeira é ou não confortável para um funcionário trabalhar oito horas por dia sentado, ou se uma mudança ergonômica vai lhe causar menos danos futuros nas costas, não deve ser o principal debate do campo. Claro que se existem melhorias dessa natureza desenvolvidas por designers, isso não é mal. Entretanto o que estamos tentando evidenciar aqui é que a preocupação com a cadeira do funcionário é de extrema superficialidade quando na verdade a discussão deveria ser de cunho político e social, isto é, a questão é o por que um funcionário deve trabalhar sentado em seu posto de trabalho oito horas por dia, se de acordo com Keynes já temos tecnologia suficiente para que trabalhe apenas três horas por dia, afinal a maior parte do tempo ele passa cuidando de atribuições não relacionadas com o trabalho, tal como vimos anteriormente.

Obviamente que compreendemos que o domínio técnico do designer para o desenvolvimento de produtos é fundamental, afinal essa é de fato a sua principal função profissional. O que queremos salientar é a falta de escopo teórico dentro de sua formação universitária de design, que resulta na propagação de uma ilusão de autonomia produtiva e criativa que de fato não existe, e ambas as coisas estão diretamente relacionadas. Se não debatermos as estruturas sociais e industriais em que vivemos hoje, não teremos perícia para compreender com clareza o que é isso que é design e como trabalham os profissionais do campo. Em outras palavras, o conhecimento teórico do design é uma ferramenta essencial para desmistificarmos a noção de criatividade, para termos ciência de que quando se trabalha para a indústria as decisões formais e técnicas não passam apenas pelo crivo do designer 
criador, mas que precisam de uma legitimação do dono da indústria, além de que design não é uma palavra que tem como finalidade agregar valores estéticos às coisas do mundo e nem que o designer é um "tipo" de artista. O designer é um profissional que concebe bens de consumo e que opera dentro de uma sociedade industrial, e por alguma razão essa perspectiva poucas vezes é contemplada.

Existem interseções e diferenças entre os objetos da cultura material. A análise panorâmica feita anteriormente sobre os objetos industriais, tendo como ponto de discussão a defesa da noção de que para falarmos de um objeto é preciso colocá-lo dentro de um contexto social e político e não o observar apenas de acordo com suas características estéticas, nos abre espaço para prosseguirmos com a observação de outros objetos, as peças artesanais.

Tal como os objetos industriais, para compreendermos simbolicamente os objetos artesanais e a sua produção é necessário que nossa análise seja realizada contextualizando o meio social em que eles são concebidos, comercializados e expostos. Pois apesar de possuírem conotações simbólicas diferentes dos objetos industriais, as peças de artesanato estão igualmente inseridas no conjunto da cultura material, e é preciso compreender que seus significados também são alterados por fatores externos em relação as suas formas - suas configurações estéticas - e funcionalidade. Do mesmo modo é preciso considerar quem legitima seus valores simbólicos e até mesmo seu uso, pois em geral as instâncias de legitimação estão muito distantes de quem o produz.

Culturalmente, não apenas no Brasil, mas em toda América Latina, as peças de artesanato são em sua maioria produzidas por grupos indígenas ou povos de origem mestiça, onde originalmente o objeto era confeccionado para uso pessoal destes povos. Os materiais utilizados na produção podem variar muito de acordo com a região, assim como a configuração estética, os grafismos ou a simbologia religiosa. Queremos dizer com isso que dentro de sociedades tidas como não complexas, as práticas artesanais eram e de certo modo ainda são utilizadas para construir toda uma variedade de objetos que supriam a totalidade das necessidades funcionais, práticas e religiosas de cada etnia específica. Esteiras para dormir, moringas para conservar água, ocas para morar, arcos para caçar, cocares para indicar hierarquia ou para manifestações ritualísticas, assim como os colares e a indumentária. Ou seja, as sociedades não complexas produziam o 
equivalente de todos os seus bens de consumo das sociedades complexas, na qual alguns possuíam função prática e outras simbologias religiosas.

A cultura indígena nos é apresentada como o grau zero das relações sociais, como nós éramos antes de sermos culturas históricas, antes de saber ler, escrever e contar. A isso se deve nosso interesse, ou o interesse antropológico moderno, pelas culturas não complexas. Tenta-se observar aquilo que a complexidade da nossa sociedade não mais permite (CIPINIUK, 2014: 104).

Esta divisão nada mais é do que algo que praticamos hoje dentro das nossas sociedades urbanas e complexas, juntamente com nossos objetos industriais. Entretanto optamos por dar certa ênfase a uma setorização que nos parece tão óbvia para tratar agora de como esses objetos, que internamente são muito bem definidos em termos funcionais e simbólicos, porém quando são deslocados para os centros urbanos e consumidos como objetos decorativos nas casas das famílias burguesas e mesclados a outros objetos da cultura material, têm seu valor de uso e sua significação alterada. Referimo-nos, por exemplo, à cestaria de origem indígena, que embora tenha sido feita para uso funcional, nos apartamentos urbanos são colocadas para decorar paredes de cozinhas, luminárias, etc. Mais adiante trataremos de forma mais específica da modificação simbólica do artesanato quando vendido a um consumidor urbano ou quando exposto em um museu ou feira de objetos artesanais. Cabe para nós agora, analisarmos em que medida a simbologia do objeto artesanal se relaciona com a do objeto industrial e mais adiante ao objeto de arte.

Se dentro de uma produção de objetos industriais, fabricados em larga escala existe uma diferenciação nítida entre objetos carismáticos ou famosos e uma vinculação a figura autoral do designer que produziu o objeto, no artesanato popular isto ocorre da mesma forma. $\mathrm{O}$ artesanato como forma de subsistência ou de manifestação popular dentro da América Latina, possui uma grande expressão e se subdivide em categorias distintas. No cenário brasileiro podemos enumerar sem muita reflexão o artesanato indígena, o sertanejo e o ribeirinho, por exemplo. De forma superficial ligamos o primeiro a trabalhos com penas e miçangas, como os cocares e os colares indígenas, o segundo com o barro, onde os sertanejos criam moringas e outros objetos decorativos e os ribeirinhos com a madeira. 
Certamente salta à vista e temos plena consciência, que nossa análise foi extremamente superficial, e a produção artesanal dessas três regiões é muito mais complexa do que acabamos de enunciar. Mas o que desejamos apontar, é como a manufatura do produto artesanal está presente dentro do nosso contexto nacional e em todas as regiões.

As diferenças entre os objetos artesanais populares do Brasil não se dão apenas nos materiais acessíveis nas regiões aonde foram produzidos. Ou seja, em geral remetemos o nosso juízo de valor a um juízo estético, tendemos a dizer que gostamos mais das peças de barro do que das de madeira porque para a decoração das nossas casas elas funcionarão melhor do ponto de vista ornamental. Se decidimos comprar um cocar indígena para sala de visitas, provavelmente esta escolha estará ligada unicamente ao tamanho e as cores que mais combinam com os outros objetos industriais que ocupam aquele espaço. Enfim, através da compra, acabamos por classificar todo tipo de objeto e os objetos artesanais, pelas suas atribuições estéticas; forma, tamanho e cor.

Ocorre que, da mesma forma em que os objetos artísticos ou os industriais, os objetos artesanais também são submetidos a um processo de legitimação para se tornarem carismáticos, ou serem muitas vezes categorizados como obras de arte, colocando-os assim na linha tênue que o divide aquilo que pertence à esfera do artesanato, da esfera do objeto de arte. E quando falamos das divisões muitas vezes quase imperceptíveis dos Campos da Arte, do design e do artesanato, estamos em geral fazendo menção a estes objetos artesanais legitimados como carismáticos dentro do setor, aqueles que identificamos o artesão pelo nome e não apenas pela região de produção. Essa noção foi herdada do Campo da Arte na qual a autoria tem grande importância e a identidade do artista criador também influencia na valorização que a obra terá. Porém, o artesanato, opera dento de uma produção coletiva e transmitida através de gerações, onde os mais jovens aprendiam o ofício com os mais velhos. A noção de identidade estética particular de cada artesão não existia, pois ela era constituída coletivamente e a noção de autoria originalmente não era empregada. Segundo Canclini, uma grande diferença entre a forma que um operário urbano e um membro de uma comunidade indígena enxergam sua profissão se dá devido ao fato de que o operário urbano entende que sua profissão é fruto de uma escolha individual e relativa às oportunidades existentes, enquanto que o indígena se vê como membro 
de uma comunidade e desse modo sua atuação profissional é determinada pela coletividade, relacionando seu pertencimento global, cultural e econômico a seu grupo, e não como uma inserção pessoal e unitária na sociedade (Canclini, 1982: 83). E, partindo dessa concepção de coletividade dos membros de uma comunidade indígena, Canclini aponta para a individualização promovida a um artesão a partir de uma assinatura pessoal nas peças artesanais fabricadas por ele, conferindo deste modo um valor diferente, que se assemelha ao da obra de arte, tornando-a única ou diferente. "Graças a assinatura, o significado das obras artesanais deixa de ser legível pelo seu vínculo com a natureza ou com a vida social para ser lido em relação com as demais obras do mesmo autor" (Canclini, 1982: 84).

Quando se leva em consideração a autoria do artesanato, isto é, quando o nome de um artesão passa a ser conhecido dentre os demais da sua região, o seu trabalho sofre um aumento de valor financeiro ou comercial, participa de feiras expositivas ou tem sua obra utilizada na cenografia de novela da Rede Globo. ${ }^{30}$ Podemos constatar que esse artesão sofreu um processo de legitimação que transformou seu trabalho imediatamente vinculado ao seu nome. Essa transformação quanto a atribuição da peça à pessoa, a um indivíduo em particular e não ao povoado ou região também transforma o sentido simbólico do objeto. Com isso verificamos que um objeto originalmente ritualístico, por exemplo, que era valorizado internamente pelas crenças vinculadas a ele, se tornam um objeto "digno de contemplação" graças a quem o legitimou e, sendo assim, ascendeu socialmente e passou a ser um objeto "decorativo" para ser contemplado como uma estátua grega, seu valor se alterou e o juízo estético ou valor de mercado frequentemente tornam-se mais importantes.

No artesanato brasileiro existem muitos mestres consagrados (vale atentar para a titulação de mestre, que já demonstra que por um processo de legitimação, este artesão é contemplado com alguma glorificação perante a outros de sua região. Isto é, o mestre é aquele que possui mais experiência, que repassa o ofício aos outros mais jovens de forma assistemática. A legitimação do mestre pode ocorrer internamente sem necessariamente ser reconhecido nos centros urbanos,

\footnotetext{
${ }^{30}$ Utilizamos esse exemplo pelo fato de que constantemente peças de artesãos brasileiros são usadas em cenários de novelas como objetos decorativos em casas dos núcleos mais abastados ou burgueses durante a trama encenada.
} 
mas também produz uma diferenciação social necessária quando suas peças são comercializadas para uma burguesia, com fim decorativo) e são a eles que em geral nos referimos quando pensamos em artesanato popular. Verifica-se também que na região do nordeste do Brasil, a arte erudita ${ }^{31}$ é muito influenciada pela estética do artesanato popular como símbolo da região. As xilogravuras do J. Borges, por exemplo, que ilustram literatura de cordel, hoje são reproduzidas em inúmeros suportes diferentes e vendidas a turistas, como chaveiros, bolsas, blusas, abridores de garrafas e etc. E, apesar de a técnica dominada por ele ser para impressão de ilustração, os impressos fazem parte do universo simbólico do artesanato nordestino. Mestre Vitalino é outro artesão que recebeu as bênçãos do grande público e também é reconhecido pelo seu nome, além de ser massivamente copiado $^{32}$ por outros artesãos. Por fim, é evidente que dentro do Campo do Artesanato, caso possamos empregar esse conceito, também existem os objetos e os produtores carismáticos, que são aqueles que são reconhecidos pelo seu nome, que são vendidos nas feiras, que ocupam os espaços decorativos das casas da burguesia. Esses objetos legitimados se localizam no saber hegemônico na fronteira com a arte, ou muitas vezes são nomeados e consagrados como objetos do Campo da Arte.

Aquilo que acabamos de descrever sobre os objetos artesanais ocorre também com o objeto de design. O objeto industrial passa a ser considerado carismático e é visto de forma romantizada pelos consumidores em comparação aos demais objetos industriais tal como o exemplo do espremedor de laranjas que empregamos mais acima. A origem e o desenvolvimento do artesanato popular e dos objetos industriais no Brasil nos dias de hoje são um importante reflexo do cenário político e social que vivemos e é preciso que essa análise seja feita. Mais adiante trataremos desta questão de forma mais pontual, cabe agora dar procedência a análise do objeto artesanal em comparação ao industrial.

Se consideramos que existem os objetos artesanais legitimados e que são

31 Fazemos referência aqui a Ariano Suassuna que em sua obra teatral "O auto da Compadecida" (SUASSUNA, A. O auto da Compadecida. $39^{\circ}$ Edição. Rio de Janeiro: Editora Nova Fronteira, 2018), se deixa influenciar pelo teatro popular das feiras e das festas religiosas. Esse fenômeno de circularidade entre o erudito e o popular, ocorre na música, literatura, teatro, cinema e nas artes plásticas.

32 O termo "cópia" dentro do Campo do artesanato é um equívoco, uma vez que não o compreendemos como um processo criativo ligado a singularidades e expressividade pessoal do artesão, mas sim de um trabalho coletivo e assistemático. 
eles que ocupam os melhores lugares, isto é, os lugares de maior destaque dentro de exposições, feiras e lojas de artesanato, as exposições, feiras ou lojas mais consagradas, precisamos entender que espaço seria esse que ocupam os artesãos não reconhecidos e não compreendidos como 'criativos' ou 'artistas'. Sem dúvidas podemos encontrar essas peças em lojas menores, destinadas a venda de suvenires sem muito valor monetário e simbólico, as ditas lembrancinhas da viagem de baixo custo que levamos para um familiar e muitas vezes comprada no próprio saguão do aeroporto. Eles também estão presentes em feiras populares abertas nas ruas que acontecem diariamente (ao contrário das feiras de artesanato consagradas que em geral ocorrem 1 vez ao ano), ou em barracas improvisadas nas beiras das estradas. Esses artesãos operam em um ciclo produtivo de subsistência com um fluxo alto de fabricação. Por serem em geral essas peças tecnicamente simples e destinadas unicamente à venda - ou seja, excluem-se as possíveis atribuições simbólicas ou ritualísticas presentes no artesanato popular elas são produzidas em grande quantidade e de acordo com a demanda do mercado que elas ocupam. Essa categoria de artesanato possui perante a sociedade um status social, um valor de troca simbólica muito inferior ao artesanato consagrado. Dificilmente este tipo de peças está ocupando um lugar de destaque na decoração de uma casa burguesa ou será atribuído a ele um valor de obra de arte. Da mesma forma que um produto industrial sem o reconhecimento de objeto de design estará guardado em um armário e será considerado apenas pela sua função utilitária e não estética. Poderíamos dizer que uma peça de souvenir artesanal trazida como lembrança de uma viagem, possui um valor afetivo maior que seu valor estético, entretanto ela simboliza também uma distinção social ligada a viagem em si, isto é, uma 'lembrancinha' de Patamban, comunidade no México conhecida pela produção de cerâmica, confirma a ida ao México, independentemente do valor estético e monetário do objeto, mas o fato de se fazer uma viagem internacional está diretamente ligado a distinção social que isso simboliza dentro da sociedade.

Podemos estabelecer relações ou associações dentro do Campo da Arte com os quadros vendidos em feiras urbanas, como por exemplo na feira Hippie no Rio de Janeiro, que ocorre aos domingos na praça General Osório em Ipanema. É indiscutível que as telas vendidas na feira Hippie são pinturas, e pinturas em tela estão dentro dos objetos que associamos ao Campo da Arte, porém não 
consideramos essas telas como obras de arte, pois não foram legitimadas como tal, e ao mesmo tempo não tratamos elas como artesanato, pois possuem um caráter de produção diferente. $\mathrm{O}$ artesanato ainda é atribuído a uma produção coletiva e sem intencionalidade de representação de um traço pessoal do artesão. Entretanto de um quadro, espera-se uma expressão do artista única ou singular, e acredita-se que esse tipo de trabalho é feito de forma individual e criativa. Constatamos assim que existem espaços fronteiriços entre os campos e que as classificações são complexas e difíceis de se estabelecer, onde os processos de legitimação que transformam o objeto em artístico ou carismático são essenciais para classificarmos cada um deles. Ou seja, são fatores políticos, sociais e econômicos que deveras atribuem valor ao objeto e não sua qualidade estética ou funcional como somos levados romanticamente a acreditar.

Outro ponto de interseção dentro das fronteiras dos campos é a que ocorre entre o artesanato e o design. É comum vermos produtos idênticos a clássicos produtos artesanais, como as moringas de barro, porém de fabricação industrial, sendo vendidos em lojas de objetos industriais. Isso acontece também com cerâmicas com grafismos indígenas, cestarias, objetos decorativos em madeira, mantas de rendas e muitos outros. Em suma, uma parcela dos produtos do artesanato popular e entendidos hegemonicamente como tal, hoje já são reproduzidos em larga escala pela indústria e vendidos em lojas de centros urbanos. Podemos entender com isso que o aspecto social e simbólico do artesanato em geral não é para o consumidor algo que seja primordial no momento da compra, sendo considerado apenas o valor estético ou decorativo. Se para alguns a história do produto é importante, o lugar de confecção, o capital financeiro que o artesanato proporciona para determinadas comunidades, o apelo simbólico das peças ou até mesmo o status social que carrega uma peça comprada em um lugar distante, para a maioria dos consumidores urbanos, o que vale de fato é o apelo estético da peça, sendo assim indiferente que processo de produção foi utilizado na fabricação do objeto.

$\mathrm{O}$ artesanato é adquirido na maioria das vezes pelo seu desenho, pela sua adequação a algum lugar na casa que se quer decorar ou para ser presenteado com fins semelhantes. Sem dúvida, isso corresponde a inclinações prévias a entrada dos consumidores na loja (CANCLINI, 1982: 102). 
Utilizamos como exemplo a loja Tok \& Stok, que possui mais de 40 filiais por todo país. Segundo o site da loja eles oferecem "Design, produtos exclusivos e o oferecimento de soluções práticas para o dia-a-dia fazem parte do conceito da Tok \& Stok, que procura sempre aliar desenho arrojado a bons preços". (https://www.tokstok.com.br/empresa/sobre-a-tokstok. Acesso em 09/09/2018) A loja trabalha com artigos para casa e escritório, atendendo a demandas tanto de mobiliário, decoração e objetos funcionais como cabides, toalhas e panelas. Enfim, em uma visita à loja você poderia comprar todo tipo de objeto industrial para montar uma casa e em geral os objetos vendidos têm o apelo de objeto carismático, ou seja, objetos de design assinados por algum designer famoso. Entretanto podemos apontar alguns grupos diferentes de objetos, na qual alguns são desenhados pelos próprios funcionários da área de design da marca, outros são réplicas de objetos famosos que originalmente possuem valores altíssimos, e quando vendidos como uma reprodução da Tok \& Stok atingem preços mais acessíveis, objetos 'artesanais' produzidos industrialmente e objetos artesanais comprados de artesãos e revendidos na loja. O site da loja está divido em categorias de objetos e dentro da categoria de acessórios existe uma subcategoria de artesanato. Este espaço seria teoricamente destinado aos produtos que foram fabricados por artesãos ou cooperativas espalhadas pelo Brasil e algumas das fotos de objeto são acompanhadas de um breve texto sobre o produtor. Entretanto há uma mescla entre produtos industriais e artesanais dentro de cada seção. Um exemplo de produto artesanal vendido como objeto decorativo pela Tok \& Stok são as peças de barro do mestre Leonildo Nascimento de Caruaru - PE, elas vêm acompanhadas do seguinte texto:

Com o talento das mãos experientes do artesão Leonildo Nascimento, os adornos em cerâmica pintados manualmente ganham as formas do sertão. Inspirados na obra do mestre Vitalino, são um ícone regional e imortalizam a técnica passada de pai para filho. A Tok \& Stok valoriza o artesanato brasileiro. Participe e contribua você também! (https://www.tokstok.com.br/cacto-mandacaru-e-asa-branca-adornoverde-roxo-mandacaru-asa-branca/p. Acesso em 09/09/2018).

Fazendo uma análise crítica em relação ao objeto artesanal dentro deste espaço descontextualizado de sua região natal, podemos constatar a perda 
completa da simbologia por trás do artesanato popular e a inserção deste em um espaço que originalmente é destinado aos objetos industriais, isto é, um local de vendas de mercadorias. A venda terceirizada do objeto artesanal pode ser analisada por diversos ângulos, o primeiro deles é a perda da referência histórica ou tradicional do objeto, trasladando-a para única e exclusivamente a sua valorização estética. Devemos considerar também que apesar de o artesão fabricar um número maior de peças para uma demanda de larga escala, o valor pela unidade da peça é muito inferior ao que ele ganharia vendendo diretamente ao consumidor. Podemos considerar nesse caso a Tok \& Stok como o agente legitimador do artesão Leonildo Nascimento, colocando-o em um lugar distinto de outros artesãos da região cujo o nome não está no site de uma grande loja nacional, apesar de isso não significar que seu faturamento seja maior ou igual à da revendedora, porque provavelmente não é.

O que desejamos trazer aqui para discussão seria compreender se existe uma diferença entre o objeto artesanal e o industrial? Afinal ambos são vendidos em uma mesma loja e passam a ser objetos carismáticos legitimados por um mercado de objetos da cultura material e tem como finalidade decorar a casa de uma burguesia que os adquire. A impessoalidade dos dois, as relações simbólicas da produção, o objeto que se vende apenas pelo apelo estético está presente tanto no artesanato quanto nos objetos de design. O deslocamento da peça artesanal do seu lugar de origem para uma loja especializada em objetos produzidos em larga escala o equipara a esses objetos. Aos olhares desatentos, pouco importa se foi o mestre Leonildo Nascimento que confeccionou a peça manualmente ou uma máquina dentro de uma fábrica, uma vez que a média de preço dos dois é muito semelhante. Então o que produz a diferença entre um objeto artesanal da Tok \& Stok e o objeto industrial é apenas a forma de produção, pois a forma de comercialização é a mesma, considerando que apenas os consumidores mais atentos questionarão ou se interessarão por essa produção. Simbolicamente ambos estão ocupando um mesmo lugar de objeto decorativo da cultura material.

Em suma, para contemplarmos os aspectos referentes às fronteiras entre os objetos dos Campos do Design, da Arte e do Artesanato, não basta apenas considerarmos os fatores estéticos que identificam cada um. É preciso considerar os aspectos produtivos (industrial ou artesanal) e suas origens sociais. Apontar para indicar que o objeto industrial é geralmente fabricado com determinados 
materiais, ou que o artesanal é manufaturado, e que o artístico é contemplativo e fruto de uma expressão individual do artista, são análises vagas e que muitas vezes podem ser aplicadas a qualquer uma das três categorias de objetos. Compreender que estas fronteiras se dão não apenas por aspectos técnicos, isto é, por forma e função, mas sim porque questões de legitimação de mercado e fatores políticos e sociais é fundamental para uma compreensão mais clara das relações dos objetos com o produtor e o consumidor e que espaço simbólico ele ocupa. Se pensarmos nessas relações graficamente fica claro que existem objetos que são mais próximos das fronteiras do que outros. Isto é, existem objetos industriais que se camuflam com artesanais, e objetos artesanais que ficam no limiar de um objeto artístico. Essas divisões se dão a partir de processos de legitimação do objeto, se são carismáticos ou não e dentro de sua categoria individual, eles podem se camuflar um dentro de outro Campo que não é o seu próprio originalmente. Então, para conseguirmos ter um olhar mais claro e crítico em relação a diferenciação dos objetos, devemos como primeira medida não os analisar de forma descontextualizada e afastada de seus aspectos históricos e sociais. As verdadeiras diferenças entre as fronteias e as categorias dos objetos se dá nestas dimensões mais subjetivas e não apenas na forma em si.

\section{2}

\section{A produção interiorana das peças de artesanato e das feiras regionais}

Tendo em mente como se constrói a visão hegemônica dos termos que empregamos ao tratarmos de cultura, acabamos por inaugurar aqui um ponto de observação relevante para uma melhor compreensão do artesanato e seus produtores no Brasil. Como recorte dessa temática, localizamos no interior nordestino polos de produção artesanal, e usaremos como exemplo um pequeno estudo empírico realizado em julho de 2017 nos estados de Alagoas e Pernambuco, a fim de compreendermos a produção e a comercialização do artesanato nestes estados pertencentes a região nordeste.

Partimos do princípio de que o artista do interior é diferente do artista urbano, que possuem culturas diferentes e daí produzem "produtos" diferenciados. 
Ocorre que embora possamos dizer que os artistas do interior realizam "obras" diferentes dos criadores das grandes cidades, há outros elementos que nos fizeram aprofundar nossas reflexões, mas o que mais marcou essa reflexão foi comprovarmos a noção de globalização da cultura, ou seja, a universalização dos valores culturais da arte em todos os rincões do país, sejam em pequenas ou grandes cidades e que se estende praticamente por todo o planeta.

Nosso primeiro ponto de parada foi a cidade de Piranhas que margeia o Rio São Francisco e divide os estados de Sergipe e Alagoas. Na margem norte do Rio, numa cidade do século XVIII que mantém a sua arquitetura original e atrai hoje um número elevado de turistas que buscam conhecer o rio São Francisco. Descendo por $40 \mathrm{~km}$ o rio em direção ao seu deságue no mar, existe um pequeno povoado no sertão alagoano datado do século XIX que possui hoje cerca de 500 habitantes chamado Ilha do Ferro, localizado no município de Pão de Açúcar. O vilarejo chamou a atenção por abrigar uma quantidade impressionante de artesãos na qual as técnicas foram passadas tradicionalmente através das gerações e permanece até hoje como símbolo local.

Quando tratamos de artesanato é necessário que lembremos que historicamente existiu a separação desta forma de trabalho, do artesão, do indivíduo que denominamos artista e que habita os grandes centros urbanos. $\mathrm{O}$ indivíduo denominado como artesão hoje é aquele que é tido socialmente como um artista menor. Não é atribuída a ele a noção de gênio criador ou detentor de um trabalho superior ou intelectualizado. Geralmente o trabalho do artesão é compreendido como um meio de subsistência, e seu produto, quando muito, isto é, quando é consagrado, é tido como algo meramente decorativo. E, da mesma forma que no Antigo Regime, o ensinamento do ofício ainda é transmitido assistematicamente através das gerações de familiares ou de pequenos grupos sociais dentro de pequenas cidades ou vilarejos.

As principais características do artesanato da região do município de Pão de Açúcar são a utilização de madeira e o bordado. O homem artesão, em sua maioria, se mantém através da pesca, do trabalho na roça ou pequena criação animal e do mesmo modo se dedicam ao artesanato com a madeira (Figuras 3 e 4). A matéria prima é essencialmente colhida na região e são usadas principalmente árvores como Mulungu, Ingazeira, Angico e Aroeira. Já as mulheres que trabalham com artesanato são bordadeiras, e além dos trabalhos domésticos que não são 
poucos, desenvolvem um tipo de bordado específico da região que se chama Boa Noite, nome inspirado em uma flor local. Esta divisão de práticas artesanais entre os homens e as mulheres é muito bem delineada, tendo cada gênero a sua forma específica de trabalho. Historicamente sempre houve uma separação clara entre homens e mulheres para a realização de trabalhos. Nessa região fora de centros urbanos, já dentro das novas noções de mercado de trabalho, característico da sociedade industrial, curiosamente verifica-se que essa divisão dos trabalhos pelo gênero do trabalhador ainda ocorre, mas especificamente no Campo do Artesanato. Homens não trabalham com bordados e mulheres não trabalham com madeira. Não tivemos ocasião de verificar esse comportamento em meio a outros trabalhos, mas acreditamos que essa divisão é recorrente.

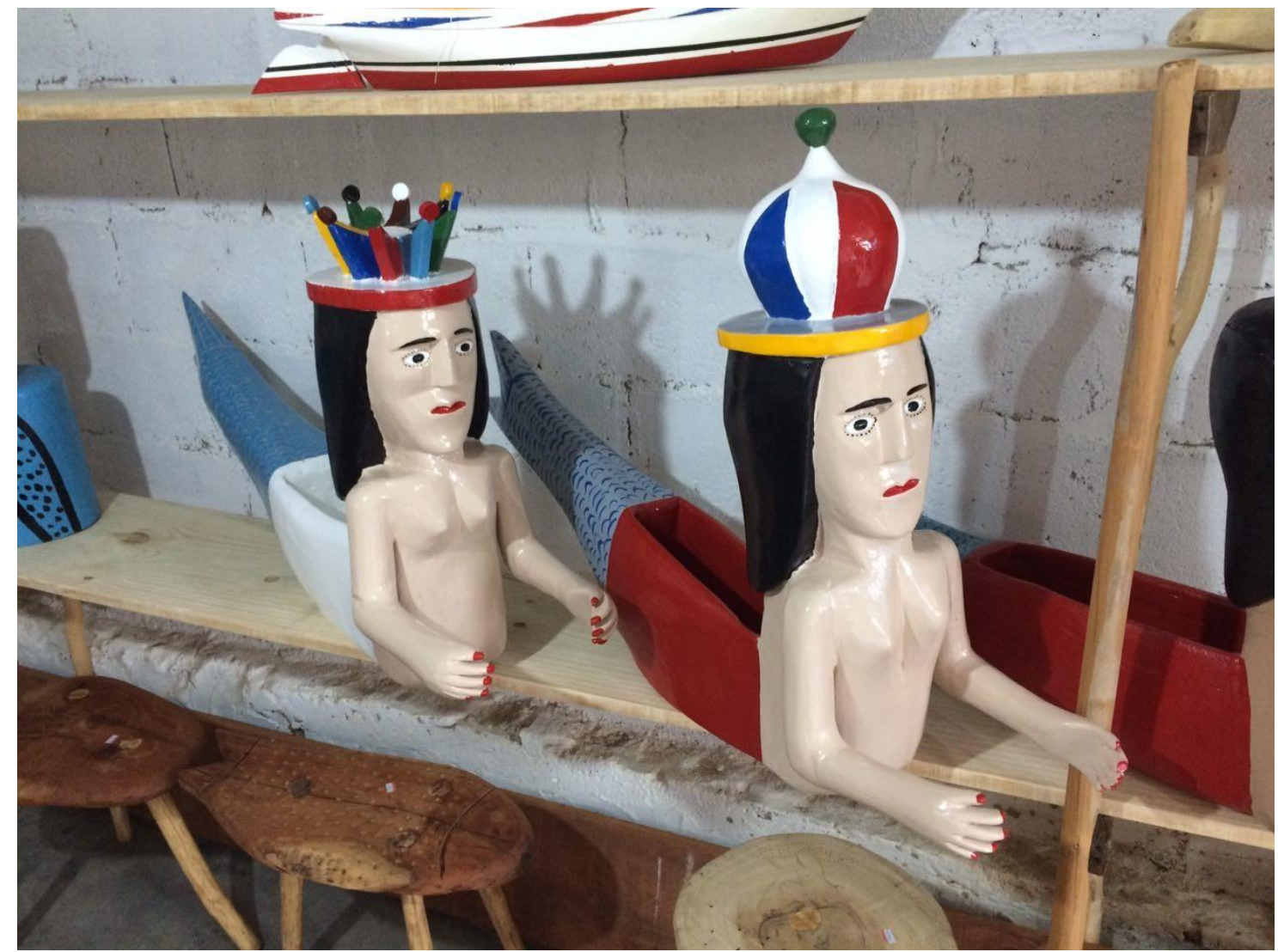

Figura 3. Artesanato produzido na Ilha do Ferro. Fotos de autoria nossa, durante a pesquisa de campo realizada em JULHO 2017. Os artesãos em geral trabalham em suas próprias casas e utilizam majoritariamente ferramentas manuais para esculpir a madeira. 


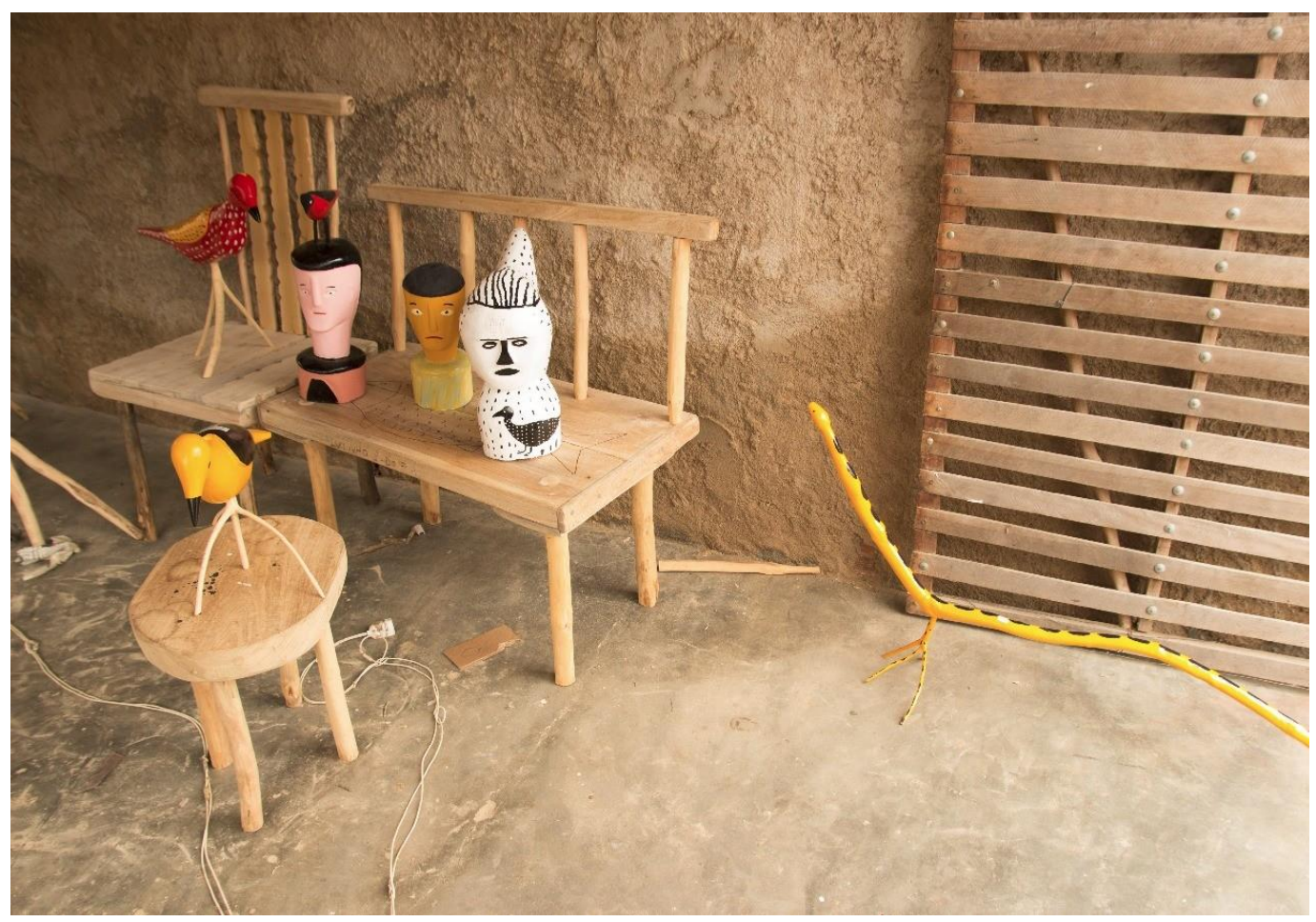

Figura 4. Artesanato produzido na Ilha do Ferro. Fotos de autoria nossa, durante a pesquisa de campo realizada em JULHO 2017. Os artesãos em geral trabalham em suas próprias casas e utilizam majoritariamente ferramentas manuais para esculpir a madeira.

Nossa busca nesta cidade foi apenas investigar panoramicamente o trabalho artesanal local, bem como conversar com seus produtores para entender uma eventual essência norteadora de suas criações, suas formas de trabalho e como isso que chamamos de mercado se agrega a este tipo de produção tradicional. Hoje o povoado já possui um público de turistas externos interessados em adquirir o artesanato local. Apesar deste número ser ainda pequeno e a cidade não possuir uma estrutura para receber pessoas de fora, tendo apenas uma pequena pousada e um restaurante, alguns artesãos da Ilha do Ferro já obtiveram um reconhecimento ou consagração que poderíamos chamar de significativo, tendo obras espalhadas por diversos estados da federação. Muitos deles já participam de feiras de arte pelo Nordeste e durante as entrevistas contaram que a receptividade comercial dos seus trabalhos é bastante boa, bem como a renda pela venda também é significativa. Recentemente foi construído na cidade um pequeno museu - uma instituição de legitimação e consagração de artistas e obras no sentido moderno - com um acervo local de artesanato e todas as casas dos mestres artesãos foram mapeadas e são sinalizadas com uma placa, a fim de facilitar a busca dos interessados em conhecer sua produção, isto é, geralmente de turistas. A 
construção do museu realizada por órgãos públicos não só impulsionou a venda das mercadorias, isto é, as peças de artesanato, mas também legitimou a produção local, e agiu como uma espécie de mecenato das instituições públicas para esse trabalho realizado na Ilha do Ferro, que é a forma mais significativa de subsistência de seus artesãos, enfim, pode-se afirmar que funciona dentro de uma ideologia comercial.

Conversando com os artesãos locais pudemos notar que existe uma hierarquia velada, isto é, não enunciada, estabelecida entre eles, onde os mais velhos ainda são tidos como mestres e respeitados pelos mais jovens. Bem como, aqueles que não são nativos da ilha também se colocam na posição de "eternos" aprendizes daqueles mais velhos. Esta hierarquização parece se justificar pelo fato de que o ensinamento do ofício é normalmente transmitido entre as gerações, como acontecia no período anterior a Idade Moderna, daí a existência de fortes laços sociais entre os velhos e jovens.

Outra questão que pudemos verificar foi o êxodo dos jovens adultos para cidades maiores com intenção de estudar e trabalhar. As áreas rurais, por mais isoladas que sejam, também já foram alcançadas pelo capitalismo ou pela economia de mercado, e os meios de subsistência dentro desse sistema nessas regiões é precário e as possibilidades de trabalho são muito reduzidas, daí essa situação que se configura como uma verdadeira expulsão da terra onde se nasceu. A ideia romântica de vida rural não é sustentável dentro da sociedade capitalista.

Entretanto, caso já não esteja acontecendo, isto nos pareceu ser uma estratégia econômica que culminará no começo de uma perda da tradição do artesanato nessa e em outras regiões do interior, devido ao fato do interesse dos jovens de se tornarem aprendizes desta cultura estar se esvaindo justamente por conta da sua ausência de pessoas na região. A Ilha, assim como grande parte do Nordeste possui graves problemas sociais e econômicos, onde a fonte de renda e o acesso à saúde e educação são limitados e grande parte da população conta com benefícios sociais públicos, o que acaba levando a saída dos jovens em busca de outras oportunidades. Já os mais velhos em sua maioria tiveram apenas a educação básica, e todo conhecimento adquirido do trabalho artesanal foi passado através das gerações e possuem a característica em comum da abordagem de formas e temas folclóricos muito presentes dentro da cultura nordestina. 
Depois de investigarmos um pouco mais esta cidade ribeirinha construída à margem do rio São Francisco que perpetua a tradição do artesanato passada de pai para filho e que, por conta disso, produz coesão social na maior parte da cidade, continuamos nossa busca por "artistas" nordestinos e seguimos para o sertão pernambucano. O vale do Catimbau é uma reserva florestal no agreste de Pernambuco, dentro do município de Buique, localizado a $350 \mathrm{~km}$ de Recife. A reserva é conhecida principalmente pela natureza local e seu parque arqueológico de pinturas rupestres.

Vilarejos como o Vale do Catimbau ainda funcionam dentro de um processo de acumulação primitiva, e não se integram completamente aos moldes sociais capitalistas modernos. A acumulação primitiva do capital foi um processo de acumulação de riquezas ocorrido na Europa entre os séculos XVI e XVIII. Ela foi substituída pelo modo de produção capitalista, onde ocorreu a expropriação da produção familiar, artesanal, camponesa e corporativa, quando o produtor foi separado dos seus meios de produção, formando uma força de trabalho livre e disponível para ser comprada pela grande indústria, nas fábricas situadas nas grandes cidades. O interior do Brasil, principalmente nas áreas mais isoladas e pobres, a subsistência de seus moradores ainda é baseada na produção familiar, seja ela agrícola ou artesanal.

O vilarejo em si não oferece uma produção de artesanato, entretanto existem dois artistas na região que moram afastados da vila em casas de pau a pique (taipa de mão) dentro da caatinga que despertaram nosso interesse. $\mathrm{O}$ mais velho deles é o mestre José Bezerra, que além de artesão também sobrevive com o trabalho da roça e uma pequena criação de animais. A região, diferentemente da Ilha do Ferro, sofre muito com a falta de água de chuva e assim é ainda mais pobre do que as cidades ribeirinhas de Alagoas. José Bezerra trabalha com artesanato em madeira (Figura 5), e com madeiras da região e tem suas obras expostas em inúmeros museus de arte popular em Pernambuco e no Brasil, já tendo inclusive participado de exposições na Europa. Ele relatou que não tem pretensão de sair da pequena casa de barro que vive, nem do sertão. Alega que seu trabalho é necessidade pessoal e espiritual (o termo é nosso), pois aquilo nunca foi mostrado por outra pessoa, ele diz ter sentido a importância de encontrar formas de animais nos troncos das árvores. 
Assim, pudemos identificar concretamente que a enunciação nas palavras do artesão, que reitera a ideia dominante desde o final da Idade Média, que o artista é dotado de um dom divino e que não foram as circunstâncias sociais miseráveis que o levaram a este trabalho, mas que poderiam ser quaisquer outras, incluindo o contrário daquilo que ocorre. O todo se explica como algo de natureza maior ou transcendental, inexplicável e incontrolável, que se coloca como destino ou necessidade vital de expressar algo que não sabe bem o que é através da arte de tirar animais dos troncos das árvores da caatinga. Esta ideia está tão enraizada dentro do panorama social, mesmo que seja em um lugar assim distante, que a crença do artesão de que de fato sua produção é uma ação livre e uma escolha espontânea, ainda que determinada por deus, torna-se real para ele. José Bezerra relata que depois de se perceber de acordo com aquilo que sua disposição social guardava para ele como artesão, passou a ensinar sua técnica e suas crenças para outros nativos, dentre eles Luiz Benício, o segundo artesão que tivemos ocasião de conversar no vale do Catimbau.

O artesão mora próximo ao seu mestre e foi José Bezerra quem o introduziu ao trabalho com madeira. Apesar de os dois argumentarem de modo parecido sobre a da produção que realizam (ambos produzem suas peças com a madeira morta coletada na região), seus trabalhos têm uma configuração bem distinta. Luiz trabalha com esculturas em tamanho grande (geralmente sendo maiores do que o próprio escultor), e suas formas são mais figurativas, abrangendo não apenas animais, mas também santos, pessoas, entidades folclóricas etc. (Figura $6)$.

Luiz Benício nos contou um pouco da história de como começou o trabalho com madeira e a experiência com José Bezerra. Segundo ele em sua tradição familiar todos os seus antepassados trabalhavam na roça em plantações e criação de animais, e ele nunca teve interesse em seguir estes passos, foi quando ele se descobriu no trabalho de seu vizinho artesão. Luiz contou que começou fazendo pequenos tatus, e hoje ele já vende obras para vários países, com valores que chegam a 20 mil reais. Quando estivemos lá no vilarejo ele nos mostrou alguns processos do trabalho que estava desenvolvendo, dois seguiriam para o Rio de Janeiro e outro para a Argélia.

Assim como na Ilha do Ferro e no Antigo Regime de modo geral, o artesanato mantinha e mantém essa característica de ser ensinado através de 
gerações entre pessoas de um mesmo estrato social. Essa forma de trabalho nessas regiões isoladas ainda hoje é uma forma de subsistência, mas é também e curiosamente, encarado como mercadoria, onde aqueles que o fazem são possuidores dos meios de produção de um produto de mercado com caráter decorativo. $\mathrm{O}$ artesanato popular existe para quem os faz como forma de comércio, enfim, para ser trocado por dinheiro e se possível por distinção social como algo superior às demais formas de mercadorias da região. Porém, o que pudemos notar é que não existe a intenção de esconder essa noção comercial em relação ao que produzem e ao próprio trabalho que realizam e a forma como lidam em relação com o que desejam sobre suas peças, isto é, não existe nenhum pudor em relação ao fato de que desejam comercializar suas peças.

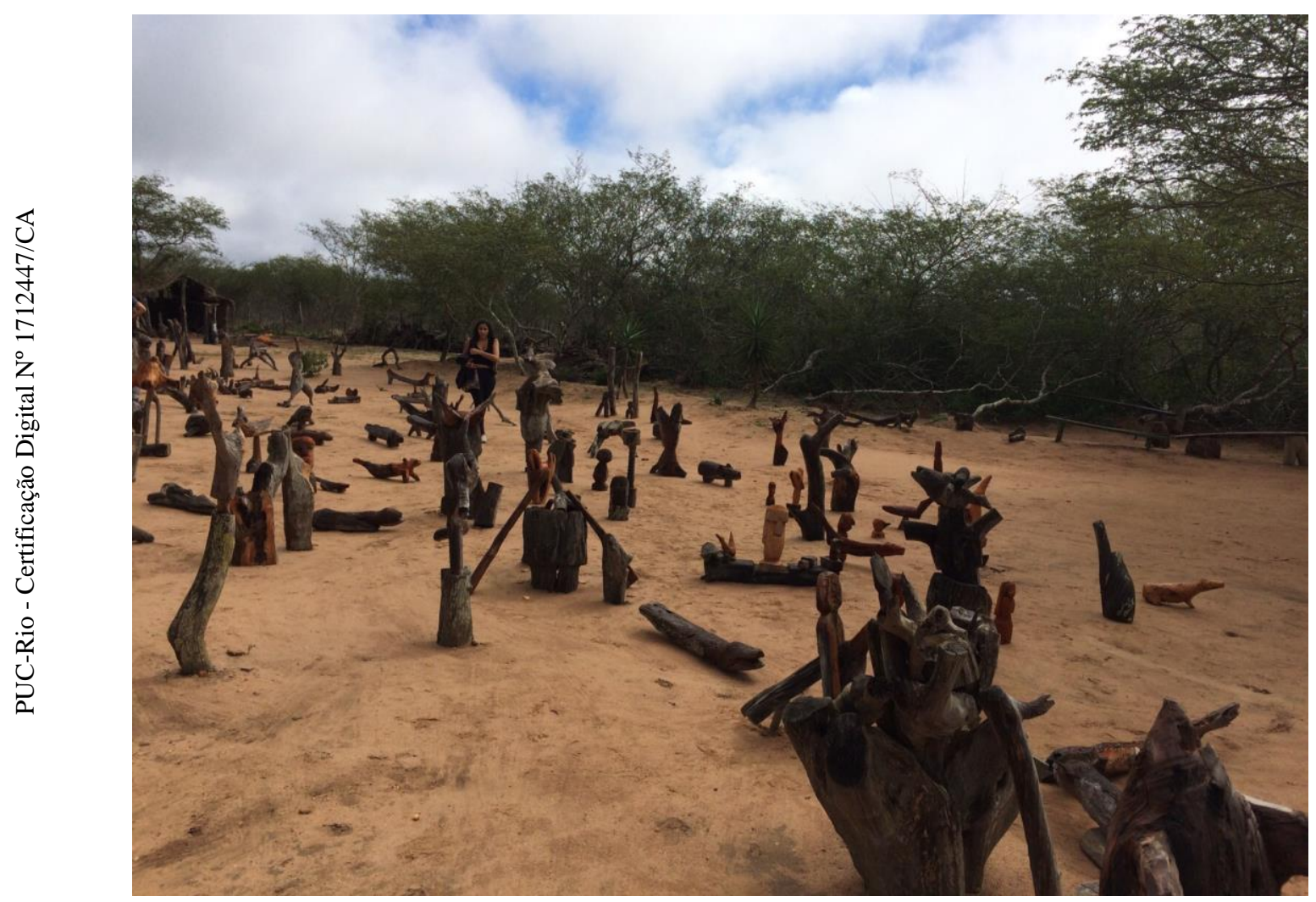

Figura 5. Oficina do Zé Bezerra - Vale do Catimbau PE. Pátio de exibição das peças em madeira, no sítio em que vive e trabalha. 


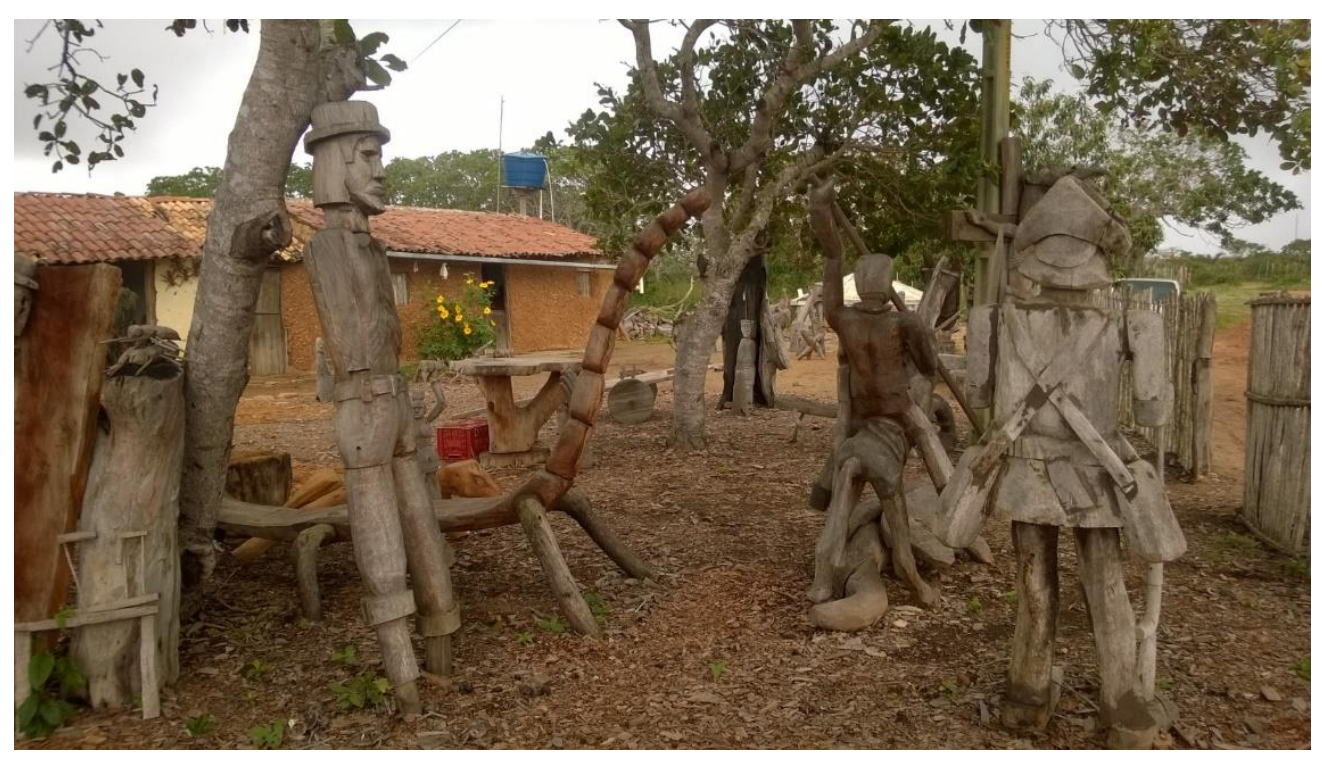

Figura 6. Oficina Luiz Benício - Vale do Catimbau PE.

A comercialização do artesanato dentro do contexto nacional ocorre geralmente de três formas; venda direta do artesão, por meio de intermediários a pequenas lojas e pelas feiras anuais de artesanato. Independentemente de qual dos meios de comercialização foi utilizado, eles possuem características simbólicas no que se trata de seus consumidores e seu uso depois que deslocado. Os objetos artesanais apesar de serem produzidos nas áreas rurais são vendidos normalmente a turistas vindos dos meios urbanos. Geralmente de origem camponesa ou indígena, eles originalmente são ligados a uma série de associações simbólicas próprias de cada lugar. A cultura indígena, salvo erro, é muito clara nos ornamentos empregados. Não pudemos identificar se eram falsas (indígena para turistas) ou não, de todo modo distingue-se das formas que estamos nomeando de camponesas. Um cocar indígena por exemplo, é mais que um adorno, cada forma ou cor tem um significado simbólico dentro de uma tribo e tal como vimos mais acima, quando ele é vendido como artesanato torna-se um ornamento para o deleite estético de gente sofisticada que "entende" de culturas exóticas. O que ocorre de forma contrária também, como com as moringas de barro do sertão brasileiro, que perdem sua função utilitária tradicional e viram objetos decorativos nas varandas das casas de campo da alta burguesia. Os objetos artesanais quando deslocados do seu local de origem transmutam de significado. Seria etnocêntrico pensarmos que o significado se perde e não que ele se transforma quando passa de um sistema cultural para outro, ele ganha novos entendimentos sociais e simbólicos. A visão 
purista da perda total da identidade se torna taxativa e elitista, pois assumimos assim a posição de quem quer manter essas sociedades marginalizadas distantes, intocadas, como uma peça de museu em uma redoma de vidro, sem contato com a modernização da sociedade. É preciso levarmos em conta mais do que os aspectos referentes a transformação de significado, pois se analisarmos apenas por essa ótica desconsideramos que o artesanato é mais que um símbolo cultural, é um objeto de mercado. E mais, também subjugamos o artesão e o afastamos da possibilidade de escolha de venda. Vale ressaltar que os produtores de artesanato se beneficiam do deslocamento simbólico do objeto, uma vez que para ele a venda é sua fonte de renda. Existe uma adaptação na fabricação do objeto, modificando-o do original para que ele seja vendido mais facilmente e tendo diferença de uso ou não, essa circulação de bens permite que seus significados de alguma forma participem de outro sistema sociocultural. "Nesses movimentos, comunicam-se significados, que são recebidos, reprocessados e recodificados". (CANCLINI, 2004: 43).

Observar a migração dos produtos artesanais nos permitiu ter uma compreensão de como o capitalismo foi introduzido nas culturas tradicionais, no qual um objeto originalmente de cunho simbólico e ritualístico se tornou mercadoria dentro do sistema capitalista, o que levou a uma subordinação dessas culturas tidas como não complexas a um modelo de comércio e consumo ditado pelos grandes centros, descontextualizando e ressignificando o artesanato.

Este processo de mudança de significado do artesanato que ocorre devido a trajetória que ele percorreu, tem como ponto inicial a sua produção e como final o seu uso pelo consumidor. Entretanto entre estes dois extremos temos o mercado que influência tanto nas relações de venda com o artesão quanto nas relações de compra do consumidor final. Como mencionado anteriormente, podemos observar diferentes tipos de pontos de venda de artesanato e as relações são distintas em cada um deles. A venda direta, feita pelo próprio artesão que muitas vezes ocorre na sua oficina quando turistas estão visitando a região, permite um contato direto com o produtor e uma proximidade com a história e o uso do objeto, que muitas vezes originalmente não são de cunho decorativo e ganham esta característica quando deslocados ao espaço urbano. Simbolicamente, esse objeto carrega uma história mais íntima no momento que para o consumidor ele está contextualizado em determinado local e sabe-se que foi produzida por uma pessoa específica e que 
possui seus significados próprios. Além disso, a vantagem para o artesão é de vender as peças por um valor determinado por ele no qual os lucros também acontecem de forma integral.

Os postos de venda em geral não são controlados pelos povos que fabricam as peças e quando estes objetos necessitam de um intermediário para serem vendidos por pequenas lojas urbanas, eles se misturam a outros objetos de outras regiões e em geral não ocorre uma classificação de acordo com o artesão, mas sim do local de fabricação. Por outro lado, o artesanato, por ser um ofício coletivizado, não possui a pretensão por parte dos artesãos de se produzirem peças únicas, ou que cada um deles possua traços característicos próprios. A ideia de pertencimento, de autor da peça de artesanato não está presente dentro das comunidades originalmente. Isso passa a ser imposto por instituições urbanas com a comercialização das peças. Logo, a ideia de autoria é própria da noção erudita de arte e não do artesanato. Porém, independente do que o artesão espera em relação a reconhecimento individual ou coletivo, não se altera o fato de que quando o objeto sai do local de produção e é comprado dentro de uma loja urbana, o seu significado e simbologia originais são perdidos, em geral nem o próprio vendedor é capaz de dar informações mais específicas sobre a peça. A apropriação do produto se dá de forma individual e silenciosa, onde o uso puramente decorativo é o principal chamariz, e as funções originais simbólicas ou funcionais são deixadas de lado.

É necessário também apontarmos a diferença entre consumidores, no qual um grupo compreendido como menos sofisticado consome os souvenires de viagem como uma recordação e um grupo mais sofisticado as peças artesanais, como signos de distinção, pois além de mostrar que comprador possuía os meios para realizar uma viagem para o local que adquiriu o objeto, mostra-se também os valores vinculados aos apreciadores de artesanato popular. O tipo de consumo é o que regula o mercado do artesanato e assim o que será produzido e em que quantidade aos artesãos. Aqueles que agem como os intermediários entendem a demanda do mercado e encomendam certas peças, ou sugerem temáticas novas a partir de uma técnica já dominada por determinado povoado. Nesta forma, o significado original se torna mais distante, e o poder de escolha sai da esfera das comunidades e vai para quem gerencia a circulação. 
Quando temos peças artesanais dentro dos museus por exemplo, o deslocamento simbólico continua existindo, em geral ele está descontextualizado do seu tempo e espaço de origem e ao lado de outras peças se sintonizam esteticamente. No museu, ele é colocado em redoma de vidro ou em vitrines e com finalidade de ser contemplado. Porém este espaço também é um lugar de fetichização, onde a peça está distante do seu uso, ou do seu valor cerimonial e ritualístico, e a contemplação se dá apenas por suas virtudes estéticas.

Outro local comum na América Latina para a exibição e venda de artesanato são as grandes feiras. A cidade do Recife por exemplo, sedia uma vez por ano a maior feira artesanal da América do Sul, a FENEART. Com duração de duas semanas, a feira se divide em dois ambientes. O primeiro que abriga os mestres artesãos reconhecidos do estado, e na maioria das vezes eles estão presentes nos estandes para conversar com os consumidores interessados. Já a segunda parte da feira é destinada a comerciantes que em geral adquirem produtos e intermedeiam a venda, a curadoria neste ambiente não tem a preocupação de agrupar os estandes de acordo com qualquer tipo de padrão, ou categoria dos produtos, ou país da onde vieram, pode-se ver luminárias de sal do Himalaia trazidas do Paquistão ao lado de um expositor de doces e pimentas de Minas Gerais e blusas feitas no Complexo da Maré - RJ. Para o artesão, as grandes feiras podem tornar-se um ambiente hostil. Cria-se a ilusão de que a venda será impulsionada e a margem de lucros será alta. Mas, todo o custo de se alugar o metro quadrado de um estande, de se hospedar e se alimentar na capital afasta o produtor deste centro anual de venda de seu produto, o que dá margem a investidores externos adquirirem as peças nas oficinas por um preço muito abaixo do que venderão nas feiras, dando assim ao intermediário o poder de decidir que peças serão mais ou menos fabricadas e até requerer mudanças estéticas. Se tira a autonomia do produtor que já não participa da venda final e assim aproxima o objeto artesanal simbolicamente de um objeto de mercadoria, mais regido pelas leis do modo de produção capitalista. Na FENEARTE em especial, existe um espaço destinado a artesãos nordestinos, selecionados através de submissão de propostas que é custeado pelo SEBRAE, onde é possível a exposição e venda pelo produtor diretamente e sem os altos custos da feira, porém essa iniciativa ainda tem pequeno alcance. Em geral a feira deixou de ser o local de contato com o produtor na maioria das vezes, e é mais um espaço destinado apenas a 
comercialização através de investidores que pouca ou nenhuma relação possui com os artesãos. Já para o consumidor, cria-se a ilusão do contato mais pessoal com o objeto do que se ele for adquirido em loja. O que ocorre é que muitas vezes os vendedores por lidarem com variedade menor de produtos em cada estande, possuem mais informações do ciclo produtivo das peças, mas em pouco se difere do consumo industrial em lojas da capital.

Enfim, tanto a venda como a exibição do artesanato no Brasil, em geral o levam sempre para o lugar comum de objeto decorativo, da perda de seu valor simbólico e seu caráter ritualístico. O não contato com o produtor e a compra efetuada através de um intermediário faz com que as características originais e históricas das peças não cheguem até o consumidor final, que se preocupa geralmente com a configuração estética antes de qualquer outro fator. Além disto vimos também que dentro dos museus e do entendimento popular o artesanato não tem o mesmo reconhecimento da arte erudita e é compreendido como cultura popular, onde sua expressividade é tida de forma distinta, e até se poderia dizer inferior, às obras de artes plásticas. Podemos chegar a essa conclusão de forma muito simples quando percebemos que os espaços destinados exclusivamente a artesanato são espaços de comercialização direta, e não de contemplação. Isto também se dá pelo fato de que ele tem originalmente raízes mestiças ou indígenas nas cidades de interior, e em nosso país o auxílio social e econômico do governo pouco chega nessas regiões. $\mathrm{O}$ artesanato hoje está em uma posição de resistência cultural de quem o produz. Ele auxilia na subsistência e com isso também reduz o êxodo para as grandes cidades, além de ser elemento chave na construção do imaginário de identidade estética e artística nacional.

\section{3}

\section{Comunicação Visual e Artes Gráficas - uma visão das práticas pelos profissionais atuantes}

Pudemos fazer uma primeira análise anteriormente sobre as fronteiras entre os Campos do Design, da Arte e do Artesanato e compreender como essa lógica opera dentro do mercado industrial e assim de legitimação do mesmo. 
Analisamos as diferenças nominais hegemônicas que são utilizadas em cada uma das categorias de objetos e aonde essas fronteiras são mais distantes e aonde são mais estreitas. Desse modo, concluímos que os objetos ou os produtores carismáticos, ou legitimados, são os que mais circulam entre a porosidade das linhas demarcatórias dos Campos, e que são esses processos mercantis de legitimação ou fundados na lógica comercial, que produzem o valor simbólico e de mais valia aos objetos, colocando-os assim em locais diferenciados dentro do mundo em que vivemos e em relação aos demais objetos menos reconhecidos, sendo que em determinados casos dão a eles status de obras de arte, mesmo que seja para um mero produto artesanal ou industrial. A análise das diferenciações entre forma e função e o deslocamento do objeto também dá flexibilidade a categorização do mesmo e produz assim uma não compreensão plena por parte de um observador leigo. Dentro do universo dos especialistas da área, o que gera uma categorização equivocada é a análise do objeto de forma deslocada do mundo, isto é, quando são valorizadas as características estéticas e funcionais e deixadas de lado as simbólicas, econômicas e políticas.

Partimos primeiramente da análise dos objetos industriais e dos artesanais, traçando fronteiras entre eles e entre objetos de arte. Em seguida foi utilizado como exemplo o contexto nordestino brasileiro em um recorte artesanal de produção e a relação social deste ofício tradicional e das condições políticas e sociais da região. A partir deste momento, passaremos ao exame das linhas tênues que dividem o design gráfico, ou a comunicação visual, dos trabalhos tidos ou considerados como pertencentes ao Campo da Arte, tal como a ilustração, o desenho e a pintura. Como recorte de localização, continuaremos tratando da região Nordeste do Brasil, mais especificamente agora de Recife, a capital do estado de Pernambuco. E, diferentemente da região interiorana nordestina, onde realizamos nossa experiência empírica, Recife é um grande centro urbano, o que o leva a possuir condições sócio culturais e políticas diferentes das pequenas cidades estudadas anteriormente.

Como recorte do tema traremos em holofote as artes visuais vinculadas à Nova Música pernambucana. ${ }^{33}$ Nosso intuito é não apenas o de compreender o

${ }^{33}$ Chamo de Nova Música Pernambucana a produção musical que sofreu forte influência do MangueBeat, ou seja, que trazem a miscigenação de gêneros proposta pelo movimento, mas que não se integraram a ele por se dar em um período posterior aos anos 2000. 
que de fato é entendido por artes visuais e a qual campo de produção ela se insere, mas também por nos interessar esta relação na produção cultural que engloba tanto aspectos musicais quanto visuais no dito mercado fonográfico.

As análises dessas relações se tornam relevantes em dois pontos distintos. O primeiro diz respeito a questão do trabalho coletivo e de que forma o briefing é trabalhado em uma situação que a arte visual deve representar e identificar uma manifestação musical. Isto é, gostaríamos de saber como se dá o trabalho na prática de um artista gráfico, um designer, ou um ilustrador, tem como objetivo ao realizar a identidade visual de um CD de um músico. Indagamo-nos sobre quais seriam os aspectos técnicos, artísticos ou relativos à prática do designer, que são efetivamente priorizados na confecção da imagem cuja realização se aproxima das técnicas mais antigas de representação gráfica, ainda que possam receber acréscimos de tecnologia digital e outros incrementos que os "artistas" gráficos têm empregado. Desejamos definir até que ponto vai a autonomia criativa daquele que desenvolve o trabalho gráfico e, dependendo do trabalho profissional que exerce (designer, artista gráfico ou ilustrador) e definir a quais aspectos ou especificidades técnicas ele se atém para realizar esse trabalho. Nossa investigação pretende analisar se a escolha do desenvolvedor do projeto gráfico é feita em função de uma estética individual ou pessoal, ou se o designer ou artista se submete a um briefing pré-estipulado pelo músico ou gravadora que ele vai representar.

Em segundo lugar, outro ponto que nos desperta interesse também e que se comunica com a questão da mitificação do trabalho do artista e consequentemente do fenômeno da arte é a questão da identificação da autoria por parte do público em relação a atribuição da identidade do desenho. Ou seja, quando ocorre a distribuição de um CD (compact disk) e no momento onde se dá o seu consumo, completando assim o ciclo de sua mercantilização, perguntamo-nos a quem o consumidor ou usuário atribui a imagem estampada na capa do álbum, enfim, se é mais à banda que ele gosta de escutar, ou ao criador visual da capa? Lembrando aqui que a noção de gosto não é a mesma que Kant mencionava, uma faculdade sensível, um atributo biológico de natureza subjetiva, comum a todos os homens e que nos permite distinguir o belo e o bem. Trata-se na verdade, de uma convenção arbitrária, como todas as outras convenções, externa ao usuário, produzida coletivamente e inculcada coercitivamente, profundamente enraizada na cultura e 
que nos grupa de acordo com nossos valores de classe. É mais provável que alguém pertencente à alta burguesia, goste de champagne com caviar e odeie ou não goste de cachaça com buchada de bode.

Assim, dentro da forma de vinculação e distribuição do Campo da Música, o artista gráfico na maioria das vezes, não é reconhecido por essa criação, e se mantém em segundo plano no que se refere a referência de produção da imagem das capas de discos ou cartazes. Acreditamos que as instâncias de legitimação e consagração que operam para o caso da música, não acompanham, necessariamente, o Campo da Arte, ou mais especificamente, o subcampo das Artes Gráficas e daí suas aproximações com o Campo do Design.

Como exemplo, vamos utilizar o disco Toda Vez que eu Dou um Passo o Mundo Sai do Lugar do Siba, pois a identidade visual deste CD foi desenvolvida pelos Gêmeos (grafiteiros consagrados de São Paulo), e neste caso o reconhecimento dos artistas gráficos precede a fama do músico, então a atribuição é direta. Mas na maioria das obras desenvolvidas para disco, o artista gráfico se torna anônimo e a imagem gráfica desenvolvida para o álbum faz mais referência ao músico do que ao designer ou artista gráfico.

Quando mencionamos um regime de distribuição comercial, julgamos que seria necessário também entrar na discussão disso que é a noção de "mérito" e "fama" e como essas duas definições se relacionam com o público consumidor. Tendemos a crer que o mérito criativo de algumas pessoas é apenas uma competência pessoal ligada à competência profissional dessa categoria. Já a fama é algo externo aos méritos do criador, haja vista que se dá a posteriori, que depende também de uma aprovação de um público, envolve o conhecimento de uma história de todas as produções simbólicas que se assemelham ao que se está desejando consagrar. Uma música ao ser lançada, dialoga naturalmente com todas as outras músicas anteriores e também com aquelas que estão sendo produzidas e lançadas naquele momento. Esse diálogo é a condição de possibilidade do juízo que fazemos em relação às outras músicas e que permite sabermos se ela é melhor ou pior do que as outras. Se nesse diálogo uma música se sobressai, temos que definir por qual motivo ela discrepou positivamente, mas somente isso não garante a sua consagração. Essa aprovação não ocorre de forma natural, mas sim a partir de um processo coercitivo de inculcação guiado e definido pela indústria cultural, pelo mercado artístico, por aquilo que existia antes de "nova" música ser 
lançada. Não se trata apenas de aspectos estéticos autônomos de uma obra, mas de condições concretas de produção que dão a condição de possibilidade de sabermos que aquilo é uma música - uma produção simbólica - e que na sociedade industrial o modo de produção possui regras próprias que diferem daquilo que tinha validade no passado. Cabe aqui formular uma pergunta: se nós temos escolhas pessoais, se essa condição de natureza subjetiva realmente preside nossas escolhas, tal como preconizava Kant e consideramos que elas se dão de modo autônomo ou independente do determinismo social. Enfim, como poderiam essas escolhas se dar dentro de uma sociedade capitalista? Se elas fossem absolutamente autônomas e dependessem apenas de nossas escolhas pessoais, por qual motivo identificamos ou concordamos que existem também imposições de mercado?

Além disto vale frisar que a escolha deste ponto de vista para investigação também se relaciona com o fato de que as produções criativas dos artistas sejam transformadas em uma produção em larga escala - produção de massa voltada para um grande público, no caso da música, ou da produção industrial mecanizada, no caso na fabricação de objetos industriais - em encartes de discos, cartazes e artes visuais virtuais que compõe sites e propagandas. Neste ponto existe uma linha tênue que separa o trabalho do designer e do artista plástico de definirem como e onde os criadores se colocam neste tipo de trabalho e como enxergam essa divisão.

O estado de Pernambuco possui uma produção cultural muito vasta e diversificada, logo, para selecionar quais artistas gráficos seriam interessantes para investigar decidimos partir de um referencial que, de algum modo, pudesse dar uma unidade a esse conjunto. Em Recife, durante o Carnaval, são montados inúmeros palcos em locais públicos que são destinados a comportar shows com entrada franca, custeados pela Secretaria de Cultura através da arrecadação de impostos. Entre eles, existe um que começou em 1995, de forma independente, idealizado pelo produtor cultural Antonio Gutierrez, que tem como objetivo a geração de um espaço para que novas bandas locais pudessem se apresentar. Assim, apesar de ocorrer durante o Carnaval, o palco do Rec Beat possui uma proposta distinta dos demais palcos da cidade. Embora a sua produção e programação sejam patrocinadas pela prefeitura, esse palco possui uma organização, curadoria e identidade visual próprias, diferentemente dos outros palcos carnavalescos. O Rec Beat tem a intenção de ser um festival de bandas novas, experimentais e inusitadas 
dentro do carnaval recifense, ocorrendo simultaneamente e acolhendo um público que não necessariamente está nos blocos de frevo e maracatus tradicionais da região, enfim, trata-se de uma proposta alternativa em relação ao modo como os outros palcos operam. Além disso, a cada ano um artista gráfico é convidado para a criação da identidade visual do festival, incluindo neste trabalho a decoração do palco, os cartazes com a programação e todos os meios de vinculação para a mídia do Rec Beat.

O Festival dentro do carnaval do Recife tem por diferencial a proposta de convidar participantes de um cenário cultural não convencional, sejam eles músicos, designers ou artistas plásticos. Sua pretensão é de transmitir uma noção de movimento alternativo com uma produção que apesar de ser patrocinada pela prefeitura possui uma curadoria independente. Os cartazes desenvolvidos para a divulgação do festival ao longo dos 22 anos da história do palco, não possuem um padrão engessado, contemplando artistas novos e outros mais consagrados, alguns que já faziam parte do meio da música e outros ligados mais à cultura tradicional, enfim, abrangendo uma gama heterogênea pernambucana de artistas plásticos e designers com o fim de criar a cada ano uma identidade visual diferente.

Apesar de sutis, existem algumas distinções entre um palco tido como independente e um obviamente patrocinado por grandes indústrias e gerido diretamente por um sistema político e econômico, uma delas é a diferenciação do público em cada um. Os compreendidos como 'alternativos', como o Rec Beat, passam a ideia de uma certa distinção social e política, mas de fato ambos existem pelos mesmos meios de financiamento e seus artistas também são aqueles legitimados por uma indústria fonográfica de massa, mudando apenas a escala de alcance das propostas de trabalho cultural. Janet Wolff defende que a cultura é determinada por fatores que vão além do reflexo das estruturas econômicas e sociais, 'é mediada pela:

[...] complexidade e pela natureza contraditória dos grupos sociais nos quais se origina; é mediada pelas situações especificas de seus produtores; é mediada pela natureza da operação dos códigos e convenções estéticos através dos quais a ideologia é transformada e nos quais se expressa. (WOLLF, 1978: 85). 
Partindo desde interesse pela história, pela produção e pela estética destes vinte e dois anos de Rec Beat, decidimos fazer uma seleção de alguns dos últimos artistas gráficos ou designers gráficos, que trabalharam na criação dos cartazes do festival para tentar estabelecer um contato afim de realizar as entrevistas.

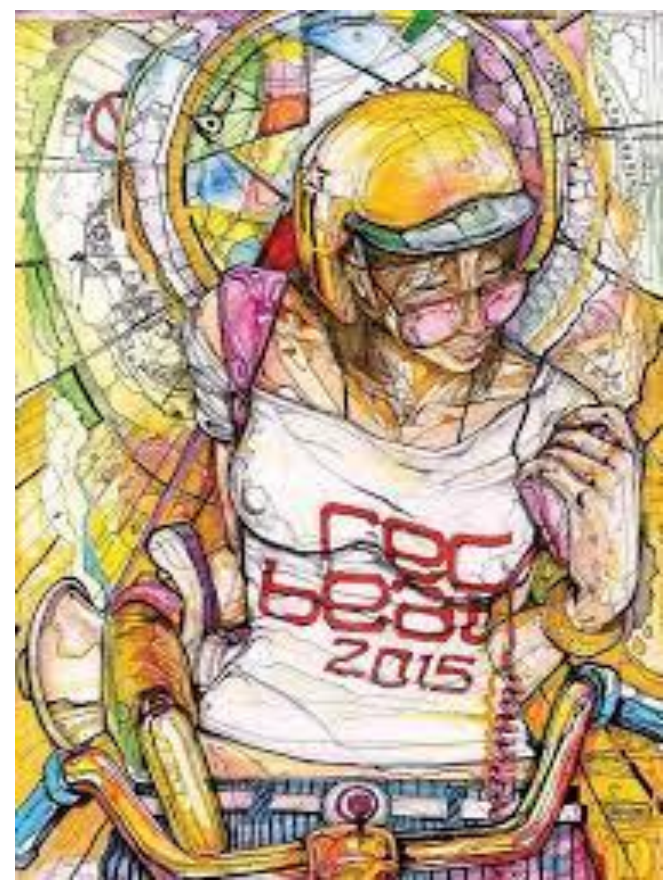

Figura 7. Cartaz RecBeat 2015 - Raoni Assis. (Fonte: http://revistaogrito.com/raoni-assis-assinao-cartaz-de-20-anos-do-rec-beat/. Acesso em 20/10/2018).

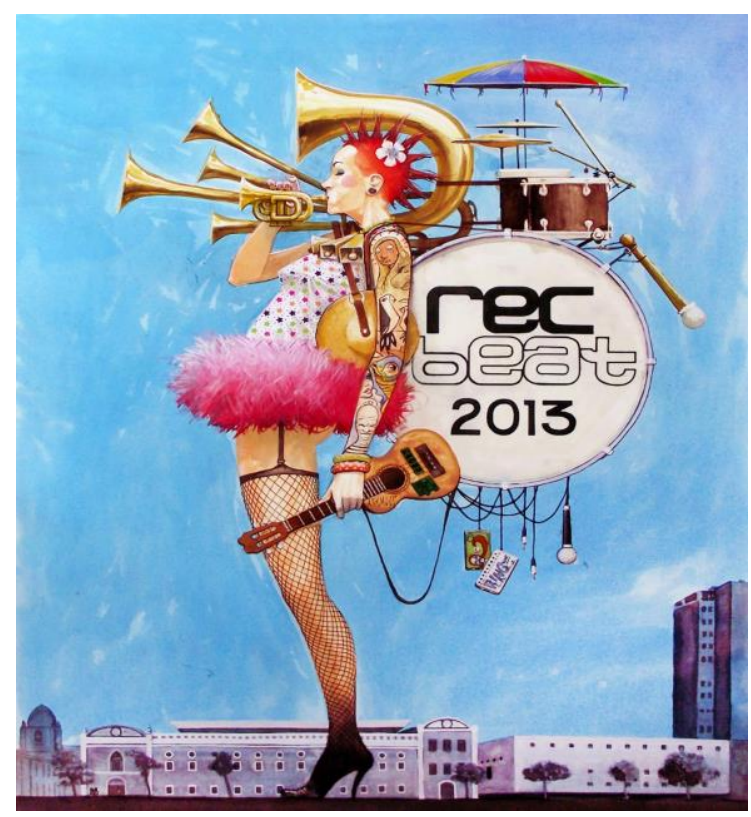

Figura 8. Cartaz RecBeat 2013 - Shiko.

(Fonte: http://www.tenhomaisdiscosqueamigos.com/2013/02/02/festival-rec-beat-divulgaprogramacao-da-edicao-2013/. Acesso em 20/10/2018). 

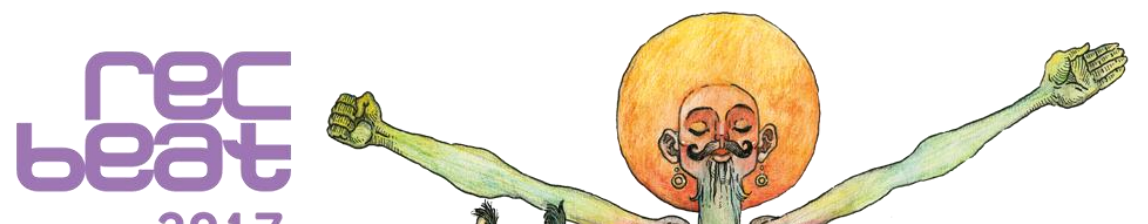

2017

cais da

alfandêga

Recife

Brasil

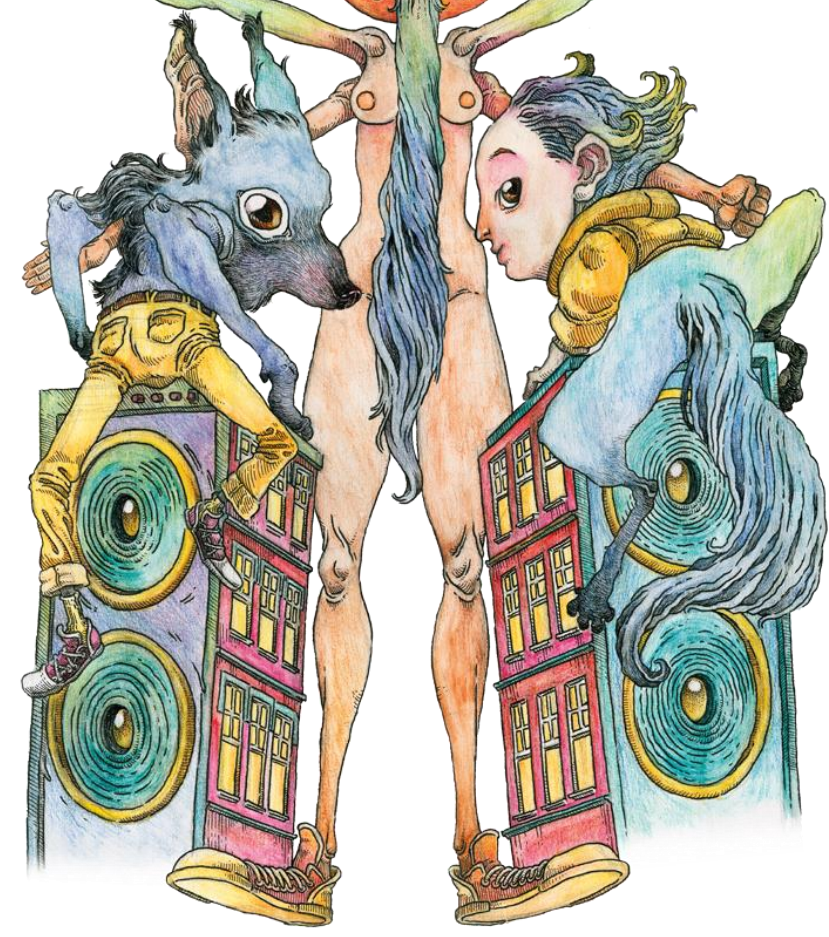

Figura 9. Cartaz RecBeat 2017 - Ayode França.

(Fonte:http://www.tenhomaisdiscosqueamigos.com/2013/02/02/festival-rec-beat-divulgaprogramacao-da-edicao-2013/. Acesso em 20/10/2018).

\section{A. RAONI ASSIS}

O nosso primeiro entrevistado foi o ilustrador Raoni Assis, responsável pelo cartaz do Rec Beat de 2015 o artista tem seu trabalho vinculado a bandas como Marsa e ilustrações no livro Tô Mirô sobre o poeta Miró da Muribeca. Com 30 anos, o olindense também é dono da casa de cultura mais importante de Olinda, A Casa do Cachorro Preto, que traz um espaço destinado a exposição e lançamento de novos artistas, assim como shows, teatro e oficinas. Formado em marketing, hoje Raoni se considera ilustrador e designer, e pude conversar um pouco com ele. Os pontos essenciais do nosso debate foram: 
MAYRA: Como você classifica seu trabalho, como arte ou como design. É possível separar isso dentro desse processo de criação de um cartaz, de uma capa que tem um briefing direcionado a outro artista?

RAONI: Eu entro mais em ilustração, sendo mais aquilo que eu falei, eu acho que é um meio termo. Eu entendo o tesão artístico da história que você não tem quando faz um trabalho encomendado, mas eu também não acho que é simplesmente uma questão técnica do tipo: - vou fazer o que me encomendaram tecnicamente, é um meio termo. Acho que ilustração é uma coisa que designa bem esse trabalho.

MAYRA: E quando você trabalha com um músico, você considera esse trabalho colaborativo, conjunto?

RAONI: Depende do trabalho, isso varia de trabalho pra trabalho, teve trabalho que eu comecei a desenhar sem nem ter ouvido o álbum, mas já sabia mais ou menos como era a banda. Mas eu considero a obra mesmo o som né, a ilustração pode nem existir. A ideia de dar uma cara pra aquela banda pode funcionar de vários jeitos, as vezes pode ser integrada e eu também já vi gente escolher desenho meu que já existia. Mas em geral é uma leitura minha do que eu vi na obra da galera.

MAYRA: E você acha que quando sua obra entra em circulação, como uma capa de $\mathrm{CD}$, você acha que ela fica vinculada a você ou ao músico?

RAONI: Eu acho que divide, um pouquinho cada um, a pessoa ouvindo aquela música vai remeter ao seu desenho, porque não é só a capa, tem o encarte, você cria uma identidade completa. Às vezes eu fico me perguntando se a galera quando escuta realmente vai na imagem. Isso é eu não sei mesmo.

MAYRA: Geralmente você trabalha com artistas independentes, mas alguma vez você chegou a fazer algum trabalho diretamente ligado com a indústria fonográfica tradicional, ou alguma instituição mais burocrática? 
RAONI: Eu fiz o cartaz da FIFA aqui, e aí tinha uma série de restrições, que eu ignorei e aí eu fiz, eu nem li na verdade, eu sei que existia porque vi muita gente falando, mas eu não li, aí eu resolvi mandar, se eles não quiserem eles pedem outra coisa, e eles aceitaram. Fiz para decoração do carnaval de Olinda há uns dois anos atrás e obviamente para prefeitura tem uma série de restrições, mas rolou também, você acaba botando subliminarmente umas ideias, mas eles limitam um pouco. $\mathrm{O}$ cotidiano já limita um bocado, você se comunicar com alguém sem ofender por exemplo, você já se limita, e isso aí em desenho é a mesma coisa, não dá pra ser você cem por cento sempre.

\section{B. SHIKO}

Shiko é quadrinista e ilustrador e foi quem desenvolveu o cartaz do Rec Beat de 2013. Com 41 anos, ele tem vasta experiência em trabalhos para capas de álbum e já foi consagrado com o $30^{\circ}$ prêmio Angelo Agostini de melhor desenhista. Hoje Shiko mora em João Pessoa, e na ocasião da minha visita ele estava desenvolvendo uma ilustração para a banda Nação Zumbi.

MAYRA: No desenvolvimento de uma capa de álbum por exemplo, você acredita ser livre para criar ou é necessário cumprir um briefing pré-estipulado?

SHIKO: No ambiente do mercado independente basicamente é o músico quem resolve essas questões e como geralmente é uma conversa entre amigos então é bem livre a criação, tem uma conversa, eu vou apresentar o que estou propondo, veja se para vocês isso reflete o que é o projeto, o que é a banda e partir disso que essa imagem é construída.

MAYRA: Mas você já chegou a trabalhar como artista que não é independente, que tenha a indústria fonográfica no meio?

SHIKO: Tem um trabalho recente que é uma produtora que tem como perfil trabalhar de maneira mais profissional artistas da periferia, artistas que não têm uma base para elaborar uma coisa mais comercial, que venda seu projeto. Então nesse caso específico que eu lembro agora, tem uma preocupação de como 
trabalhar a imagem do artista e aí isso envolve uma conversa maior, um entendimento mais complexo, então eu conversava muito mais com o produtor do que o artista, quase não conversei com o artista. Por outro lado, eu acho que meu trabalho tenha uma cara, tenha as especificidades dele e tal, com uma estética mais ou menos já bem definida que quando alguém me procura, a produtora no caso, ela já tem uma ideia clara do que eu vou apresentar, então mesmo nesse caso não há uma diferença muito grande entre o que a produtora espera e o que eu apresentaria. A diferença aí é que a conversa já não é com o artista é com a produtora, mas eu não me sinto também absolutamente travado, travado, no meu processo de criação. Em outros casos, agora mesmo ia rolar um "trampo" que acabou sendo cancelado com vários artistas, que era uma campanha para o Rock in Rio, aí tem outra dimensão, aí sim o briefing vem fechado e você executa aquilo que já veio "brifado" para você. Mas a maior parte da minha experiência que é de músicos, até mesmo o trabalho que você viu que eu estou fazendo agora, com o Nação Zumbi que é uma banda maior, que tem uma estrutura mais comercial, ainda sim a conversa é bem aberta. Mas eu acho que passa por isso, se a galera me procura é porque já tem uma ideia do que eu vou apresentar.

MAYRA: Nesse tipo de trabalho mais independente a criação é feita de forma coletiva? Ela passa por você e pelo músico?

SHIKO: Sim, até em parte por uma opção minha, como quase sempre eu tenho uma relação de amizade com essas bandas então eu até prefiro ter essa conversa com eles no momento que eu tô produzindo, eu normalmente já conheço o trabalho de alguns caras de algum tempo já e faço um esboço, ou dois, ou três e apresento a leitura que eu fiz, e normalmente essa conversa anda fácil. Às vezes quando você tenta transformar essa proposta musical numa apresentação visual dela, talvez isso às vezes coloque questões de entendimento do projeto para a banda que talvez eles não tivessem passado por elas ainda, então às vezes essa conversa fica confusa entre os integrantes. Quando complica é mais uma dificuldade do entendimento deles sobre o que é o projeto do que um ruído de comunicação entre a gente. 
MAYRA: Outra questão é a dificuldade de nomear este tipo de trabalho, se ele é um trabalho do designer ou do artista. Como você classificaria o seu trabalho?

SHIKO: Isto de que o trabalho artístico tem que estar associado a uma absoluta liberdade de execução e de conceito dos artistas, eu acho que a conversa já tem que começar aí. Porque isso inclusive é recente, então da Renascença onde tudo era encomenda até o começo do século $\mathrm{XX}$ onde artistas incríveis trabalharam "brifados", então a gente precisa primeiro definir aonde que começa o trabalho puramente artístico.

Digamos, o cara está pretendendo uma Bienal, um salão, ele sabe o perfil daquele curador, daquela Bienal, ele produz "brifados" pelo perfil da instituição, ou pelo perfil do curador, ela está sendo "brifados" pelo mercado. E também tem isso, que hoje é difícil entender que um trabalho mais próximo da ilustração seja uma arte que vá ter o mesmo conceito que uma arte mais conceitual, nesse sentido talvez até um trabalho de design vá ser mais bem aceito do que um trabalho mais figurativo, mais próximo da ilustração. Isso pra mim é um conflito de classe no final das contas, vai desaguar nisso no final das contas. Porque quem passa pela formação artística burguesa não vai se formar ilustrador, ele vai se formar um artista de vanguarda, um artista conceitual e quem passa pela formação artística burguesa tá em outra esfera social, e aí essa discussão do que é maior do que é menor, do que vale e do que não vale no final pra mim é um conflito de classes.

MAYRA: Como você vê a classificação do regionalismo que é dada a produção artística nordestina?

SHIKO: Eu sempre conto a mesma história pra falar disso. Eu estava numa bienal de grafite em $\mathrm{BH}$, isso a mais de dez anos, aí chego lá e eu era a única pessoa da Paraíba e tinha muita gente de fora, de outros países, e do Rio e de São Paulo e de $\mathrm{BH}$ e a gente foi fazer um mural junto, e fomos conversando sobre quem ia fazer o que, como elaborar e me perguntaram o que eu ia fazer, aí eu disse que ia fazer uma Gueixa, aí o pessoal disse pra eu não fazer uma Gueixa não, pra eu fazer um cangaceiro. E eu não queria fazer um cangaceiro, e começaram a questionar que eu era da Paraíba e que eu deveria fazer um cangaceiro, aí eu disse que não queria porque eu era um grafiteiro nordestino, que na minha cidade não tinha material, 
não tinha uma loja de tintas, não tem circulação de artistas de outros lugares, tudo é dificuldade. Aí você tem que passar por cima de um monte de barreira, aí quando você tá em São Paulo as facilidades são muito maiores pra você por conta do ambiente, da circulação e ninguém tá cobrando que você faça nada, ninguém quer que você faça um bandeirante. Aí depois de tudo ainda tem que ficar no curral do regional, da referência a xilogravura, do cordel ou desse nordeste histórico, folclórico, porque é isso que o Sudeste espera que venha do Nordeste. Mas é muito comum, e se espera isso da música também, se espera do cinema, que a gente no cinema fique no máximo no cinema novo de Glauber Rocha e que na música a gente pode até ir pra música eletrônica ou pro rap mas a gente tem que fazer uma costurinha ali pro regional, tem que fazer cosplay de nordestino no palco para se apresentar. Eu não estou afim disso não, nem eu e nem quase todo mundo.

\section{AYODE FRANÇA}

Ayôde é ilustrador, designer, animador e quadrinista do Recife e fez o último cartaz do Rec Beat, de 2016.

MAYRA: Uma das questões que eu queria entender nessa produção gráfica para o mercado de música é o entendimento do próprio profissional, se ele considera seu trabalho artes plásticas, design, artes gráficas ou algum outro termo?

AYODE: Na minha visão acaba passando por todos, é meio uma mistura. Por exemplo, esse trabalho que eu fiz pro Rec Beat tem essa pegada do design porque no final das contas ele é um trabalho encomendado e pensando já para ser impresso em tipos de mídia diferentes então o processo de elaboração da imagem para ser usada em uma camisa por exemplo, ela já é pensada para isso, para um cartaz, para uma campanha online.

MAYRA: E você acha que para esse tipo de trabalho existe um briefing que talvez seja mais fechado do que suas produções livres, ou você tem uma liberdade grande?

AYODE: Geralmente isso depende muito de como você desenvolveu seu trabalho ao longo do tempo, se você desenvolve um trabalho mais por encomenda você 
acaba se envolvendo mais com projetos que a pessoa que tá promovendo ele já sabe o que quer, você realiza a ideia dele, mas quando você já tem algum trabalho autoral mais divulgado você já tem mais liberdade com quem vai te contratar.

MAYRA: E para os cartazes do Rec Beat por exemplo, qual o processo de seleção? É edital?

AYODE: O pessoal do Rec Beat me ligou e disse que queriam um cartaz e me deram liberdade total para fazer o que eu quisesse. A única exigência é que tivesse um texto justificando a imagem.

MAYRA: E isso foi vinculado aonde?

AYODE: Eu acho que foi no site da revista $\mathrm{O}$ Grito, mas eu acho que foi só lá.

MAYRA: Você já chegou a trabalhar com capa de álbum?

AYODE: Já, para algumas bandas de conhecidos, já fiz capa de $\mathrm{CD}$, de ep (?) e animação para bandas.

MAYRA: E aí nesse processo quando você está trabalhando com capa você acha que a questão da divulgação do seu trabalho é mais vinculada a você ou a banda?

AYODE: Não sei como te falar como funciona a divulgação, mas eu nunca percebi nenhum retorno em relação a minha arte para a banda.

MAYRA: E você acha que esse tipo de trabalho é realizado de forma coletiva?

AYODE: Eu preferia que fosse, mas as experiências que eu tive não foram, a maioria não tá muito interessada em construir a identidade da banda, eles falam que querem uma capa, com nome da banda e falam pra eu fazer o que eu quiser. Não existe muita troca. 
MAYRA: Você vê o estigma do regionalismo no seu trabalho?

AYODE: Entra sim, existe uma relação. Às vezes entra de forma proposital, tanto para subverter os conceitos como para reforçar alguns e as vezes não entra também de forma proposital, a ideia seria você inserir novos conceitos dentro do que poderia ser considerado um trabalho regional, mas vejo nada negativo nisso não, acho até interessante, quando o trabalho artístico entra nessa parte de identidade local.

Ao final das entrevistas pudemos constatar que esta divisão entre o que é design, ilustração e artes gráficas é praticamente inexistente dentro do universo de quem as produz. Além disso, ao tratar da questão do briefing, verificamos que para cada gênero criativo ou prática específica, o termo acaba tendo uma importância determinada e não uma demanda concreta do modo de produção industrial. Acreditamos que o relato mais substancial que obtivemos foi o do Shiko, que em sua fala se colocou politicamente. Ele se mostrou como alguém que compreende que seu trabalho está e é moldado por valores de uma sociedade de mercado. Os pares dos campos da arte e do design tendem a se colocar a margem de uma demanda industrial, e negam-se a admitir a inserção em um mercado capitalista. As estruturas dentro destes campos não diferem das outras, entretanto seus componentes insistem em negar sua igualdade com todo o resto da estrutura social.

Desmistificar a noção convencional de artista e entender seu trabalho que exige treinamento, dedicação, estudo, como outro trabalho qualquer, nos faz ter maior clareza sobre o sistema político, econômico e social que gira em torno desse profissional, que atende a demandas práticas e mercadológicas. Apontamos ao longo do texto algumas posturas que encontramos no discurso dos artistas, dos artesãos e dos designers, e podemos concluir que muito pouco se modifica entre eles, mas que mesmo assim na visão hegemônica, esses três profissionais são vistos em status sociais diferentes, o que altera toda a ótica da demanda de mercado de cada um.

O fator que maiormente despertou nossa atenção foi o fato de que nenhum deles ter admitido abertamente que seus trabalhos são objeto ou resultado dos mecanismos determinados pelo mercado tal como pudemos observar entre os 
"artistas" populares. Os objetos desenvolvidos como concretização de práticas sociais ou forma de trabalho, dentro do modo de produção capitalista com intuito de transformar o valor de uso social das práticas, que ora denominamos arte, ora design, em valor de troca simbólica. Sendo que o que estamos chamando de troca simbólica é o afastamento dos verdadeiros valores humanos, aqueles associados ao valor de uso social, pelos valores de mercado. Que estão transformando objetos da cultura material e imaterial com valor de uso social em produtos ou mercadorias, isto é, em meros objetos de troca comercial, com um preço regulado pelo mecanismo de oferta e procura, ou seja, valores de mercado. Até o início da Idade Moderna essa noção não existia, mas verificamos que mesmo entre os artesãos populares do interior, que ainda guardam antigos comportamentos.

Assim, pudemos constatar que a noção dicotômica da Idade Moderna, o mito da criação como atributo de um dom divino, noção que se reflete na querela entre as artes maiores - a arte produzida pelos artistas - e as menores - a arte produzida pelos artesãos - ainda é extremamente presente, até mesmo no discurso do Shiko, quando ele traz a questão de a arte acadêmica e burguesa ter "mais valia" do que a ilustração, o que ele define como um conflito de classes. Enfim, com as entrevistas pudemos compreender mais claramente o olhar do criador sobre si mesmo, sobre suas práticas neste tipo de trabalho vinculado à música e outros gêneros artísticos ou criativos e notamos que não existe um interesse de classe por parte desses, em se definirem politicamente como uma categoria profissional, pois não existe uma noção clara e distinta desse grupo social entre aquele que é ilustrador, músico, artista ou designer. Essas práticas, específicas que sejam, são tidas mais ou menos como sendo a mesma coisa, ou seja, simplesmente arte, uma prática que não se explica cientificamente, mas algo autônomo ou independente e que se dá por razões obscuras, um “je ne sais quoi”. 


\section{4 \\ Conclusão}

De fato, a intenção [do artista ou criador] é, por sua vez, o produto das normas e das convenções sociais que contribuem para definir a fronteira, sempre incerta e historicamente mutável, entre os simples objetos técnicos e os objetos de arte (Bourdieu, 2006: 33).

Utilizando a citação de Bourdieu como epígrafe para uma pequena síntese a respeito da ideia força desse trabalho, pudemos constatar brevemente que analisamos ao longo do texto algumas das fronteiras técnicas e simbólicas que diferenciam o Campo da Arte, do Campo do Design e do Artesanato, e também a complexidade de se evidenciar essas distinções, que além de tênues muitas vezes são conflitivas ou sobrepostas e que afinal verificamos que eram difíceis de discernir. Em certos casos o mercado de trocas comerciais do capitalismo modifica a categorização de qualquer desses objetos através dos agentes legitimadores, que atribuem a determinados produtos carismáticos a simbologia de obra de arte. Entretanto resta-nos ainda nessa conclusão definir qual seria para nós a importância dessa análise? Isto é, porque definir teoricamente as fronteiras do design, da arte e do artesanato? Seria isso útil enquanto pesquisa científica no Campo do Design, uma vez que o mercado opera desta forma, tal como os pares do Campo e pouco ou quase nada resta a fazer? Nessa conclusão, portanto, ratificaremos nossa reflexão desenvolvida anteriormente respondendo a essas questões.

Nos parece claro e distinto como a noção mítica sobre o artista se reflete em outros campos que não necessariamente o Campo da Arte. Também nos parece claro como essas noções míticas influenciam diretamente o nosso entendimento sobre isso que é design. Logo, sustentamos que a definição sobre qual a área de atuação do design e da arte não está sendo bem fundamentada pelos pares hegemonicamente, verificamos que é preciso pensar por qual motivo nos deixamos influenciar por essas noções míticas. Ao tomarmos essa posição não nos referimos apenas às pessoas leigas e distantes das práticas artísticas, mas principalmente aos pares do Campo da Arte ou do design que deveriam ter como requisito básico um conhecimento histórico mínimo, assim como um pensamento crítico fundamentado 
que permitisse a consciência da verdadeira autonomia da arte e do design e o que eles representam tanto socialmente quanto para o mercado de trocas de mercadorias, isto é, de obras de arte típico do capitalismo. A crença no dom inato do artista, do artesão ou do designer de certo modo deslegitima suas práticas profissionais, afinal essa visão romântica não carrega apenas um olhar poético, transcendente das coisas materiais, como defendem alguns, sobre um profissional sensível e distinto socialmente, mas também reforça paradigmas de que artistas são "vagabundos" ou "preguiçosos" em relação ao mundo daqueles que trabalham e vivem o dia a dia, enfim, aqueles que não possuem uma rotina digna de trabalho como os demais.

Essa noção pode ser analisada por dois diferentes ângulos. O primeiro diz respeito ao trabalho do artista ou do designer em si, isto é, considera-se que o trabalho artístico destinado apenas às atribuições criativas (vale frisar que consideramos que todo trabalho é potencialmente criativo), e não a uma prática laboral que requer horas de trabalho e estudo para o desenvolvimento do sujeito social em um profissional artista. Isso se intensifica na crença de que o artista é, muitas vezes, autodidata, que simplesmente ele sabe utilizar os materiais e se relacionar com a produção artística vigente na época. É sabido que atualmente a formação do indivíduo como artista é legitimada pelas escolas ou academias de arte, ou por melhor dizer tal qual defende Bourdieu, não apenas o nível de competência artística é relacionado diretamente com o capital escolar, mas a frequência em museus e a compreensão da arte em si pressupõem um capital cultural adquirido tanto dentro das instituições de ensino como também pela classe social que influencia diretamente na trajetória social (BOURDIEU, 2002: 19). De modo que é necessária a compreensão de que o desenvolvimento de obras de arte não se dá de forma espontânea, ele é fruto de um trabalho que requer processo e assiduidade, assim como em outros gêneros da arte, tal como a música por exemplo, que nos parece mais óbvia a relação do músico com seus inúmeros ensaios ou com o domínio de um instrumento depois de anos de estudo, o que podemos entender também por treinamento, embora esse termo seja pouco empregado. Assim, acreditar unicamente e predominantemente no dom do artista desmerece o tirocínio da arte, as horas de trabalho em ateliê, a formação acadêmica, ou a busca pelo conhecimento teórico e referencial do profissional do Campo da Arte. 
Ora, se esta argumentação partisse apenas da classe dominante que por razões ímpares têm interesse em defender esta concepção, a mistificação não nos pareceria tão estranha, uma vez que sabemos que os interesses da elite criam determinados mitos sociais a fim de beneficiar a manutenção e reprodução de sua própria classe, contudo, o que nos parece mais grave, é o fato de que os pares do Campo da Arte e do Design tendem a crer nesses mitos também, prova de que a inculcação social de uma crença romântica do artista é tão enraizada que obscurece a verdadeira função e difusão da arte e do design, sem esquecer que em grande parte a própria classe profissional é parte dessa extração social. Sustentamos que quem de fato está ciente e comprometido com os mecanismos mercadológicos e ideológicos da produção criativa são os agentes de legitimação, comercialização e patrocínio, enfim, pares do campo, afinal são eles quem determinam as vias que o mercado capitalista atuará.

Logo, retornando a questão aventada no início dessa conclusão, que possuí a intenção de indagar sobre a importância de se fazer uma análise crítica a respeito da crença do artista como ser criativo, e de que forma o mercado capitalista se apropria dessa noção, nos cabe agora evidenciar por que defendemos que muitas vezes o próprio profissional do campo é assegurado por uma inocência em relação a sua atuação no mercado. Em outras palavras, verificamos que quem determina ou legitima essa crença, na maioria dos casos, não é próprio artista, mas uma disposição social, um habitus de classe ou o sistema social vigente, a própria construção social do comportamento do artista é responsável por levá-lo como vítima a se manter ignorante ou inocente e se entender como ser criativo e predestinado. Verificamos também que todos nós (os não artistas) somos induzidos a acreditar nesses mitos a partir de um processo de inculcação social repressor, na qual o artista exerce um papel na sociedade diferente dos demais trabalhadores. Dessa forma ele estaria fadado a ter determinadas características, por ter uma sensibilidade mais aguçada dentro de um contexto que marginaliza sua classe profissional.

Do mesmo modo verificamos que se fala em remuneração artística como consequência de uma expressão pessoal e não como as vias de fato, assim como qualquer outra profissão. Vale ressaltar que tratamos dessas noções nos referindo principalmente ao Campo da Arte por ela ser oriunda dele, mas hoje não mais se limita ao profissional artista, uma vez que outros setores se apropriaram dessa 
crença sobre a criatividade e o dom, como os pares do Campo do Design e do Campo do Artesanato. Como vimos, as relações funcionais e simbólicas dessas profissões são distintas, mas o que as une como práticas semelhantes é justamente a noção da produção criativa como eixo central na atuação dos profissionais de arte, de design e artesanato. Desse modo, a gigantesca dificuldade para definir fronteiras entre os campos parte desse ponto em comum entre eles, essa visão obscurecida pela noção romântica na produção de objetos da cultura material com grande apelo estético, porém que a partir de uma análise técnica produtiva ou ideológica dos pares, possuem distinções significativas.

Assim, se nós enquanto pares do Campo do Design sustentamos que os próprios profissionais atuantes em grande parte não dissimulam essa crença, que eles de fato confiam nessa concepção da noção do que é um artista, por que essa análise nos parece valorosa? Já defendemos aqui em qual momento histórico isto está situado, bem como debatemos acerca das especificidades do Campo da Arte que sustenta, e porque sustenta, a figura do artista tal qual nós o contemplamos hoje, e de que forma é possível desmontarmos essa argumentação com base nos dados do mercado de arte e também como ocorre a movimentação financeira dele.

Além disto, tratamos panoramicamente, tal Bourdieu defende, que quem domina os códigos da arte, isto é, quem não apenas frequenta os espaços destinados às exposições, mas também compreende os movimentos artísticos, ou valoriza o artesanato popular original, ou deseja os objetos carismáticos do design industrial, está dentro de um padrão social de comportamento diretamente ligado ao capital financeiro ou escolar. $\mathrm{O}$ que nos restou, portanto, foi tentar compreender de que forma aqueles que estão efetivamente dentro do Campo da Arte, ou dos demais setores que também empregam suas crenças, definir como continuam defendendo a existência do gênio, o artista romantizado, tal qual foi voga até o século XVIII.

Nos pareceu e por essa razão assim o definimos, que a validação desta noção para aqueles que estão inseridos como profissionais atuantes no Campo da Arte e do Design ocorre dentro das instituições de ensino superior comprometidas com a formação de profissionais das áreas de design e artes. ${ }^{34}$ Desse modo,

\footnotetext{
${ }^{34}$ Aqui nos abstemos de tratar do caso do artesanato, uma vez que é um ofício geralmente ensinado de forma assistemática e dentro de comunidades. O saber do artesanato, na forma que aqui tratamos, ou seja, o artesanato familiar perpetuado tal qual faziam as sociedades primitivas,
} 
quando um jovem almeja ou é levado à almejar atuar em uma dessas profissões e presta um vestibular tanto para artes como para design, é compreensível que pareça um tanto obscuro não apenas como será sua atuação profissional ao fim dos anos cursando a universidade, quanto ao esclarecimento pouco nítido em relação à forma que ambos os cursos serão ministrados, uma vez que eles são bastante distantes da ideia de educação que se constrói ao longo do ensino escolar básico. As escolas como tradicionalmente conhecemos, não contemplam o Campo do Design dentro do método de ensino, e as aulas de arte são muito distantes do que de fato será ditado pelo mercado e da produção da arte contemporaneamente. Para somar ao pouco interesse escolar em relação a essas áreas de atuação profissional, vemos as palavras arte e design serem utilizadas no nosso cotidiano de forma copiosa em circunstancias muito distantes do que nós como pares do campo compreendemos teoricamente como tal.

Design é uma palavra utilizada hoje como um indicativo para alguma prática profissional que se acredita ter uma capacidade de produzir uma estética superior, sendo então compreendido que o profissional da área é a pessoa que trabalha no desenvolvimento estético de algo ou alguma coisa. Não é incomum vermos salões de beleza que anunciam profissionais como designers de sobrancelha, designers de unha, hair designers ou make up designers.

Dentro deste contexto pode até parecer que utilizamos a palavra estética como equívoco, quando na verdade estaríamos falando de esteticistas, mas lamentavelmente não é esse o caso. Isto sem falarmos em pessoas que se auto intitulam designers por ter domínio técnico de certas ferramentas utilizadas para o desenvolvimento de projetos gráficos ou até mesmo de objetos, e assim atuam no mercado prestando serviços de designers a partir de um aprendizado técnico e autodidata. A palavra design também aparece com frequência como adjetivo em propagandas de objetos industriais e serve de termômetro para distinguir um objeto dos demais, ou seja, como um objeto industrial superior tanto na sua forma como na sua função, apenas porque foi adjetivado como um objeto com design. Logo, quando se anuncia, um carro, uma geladeira, um smartphone, uma televisão ou um sapato com design, o que se quer oferecer ao público consumidor é a noção de superioridade estética e técnica em relação aos demais, a palavra design acaba

não é institucionalizado. Entretanto o consumidor do artesanato denota a estes objetos a mesma noção romantizada que carregam os objetos artísticos. 
por legitimar uma espécie de aura ao produto, respaldada obviamente pelas ferramentas de venda do marketing.

Logo, defendemos que uma das maiores lacunas que existe para a definição da prática do design está diretamente ligada ao ensino acadêmico oferecido nas universidades, onde se contempla muito mais os aspectos técnicos do que os teóricos. Não acreditamos que se essa proporção fosse inversa o mercado se alteraria de alguma forma, isto é, se houvesse uma maior percepção por parte dos designers de como seu trabalho se insere na sociedade e ao mesmo tempo das suas reais capacidades de atuação, a indústria se modificaria e inverteria sua forma de produção dos bens de consumo. Nossa crítica aqui pretende questionar apenas a ignorância a respeito da atividade profissional real do designer e a noção romântica oriunda do Campo da Arte que é presente no setor, afinal se temos entendimento do porquê e para quem estamos projetando objetos industriais e qual será de fato nossa participação em um desenvolvimento de produtos dentro de um mercado industrial, a capacidade de elaborar um pensamento crítico sobre nosso próprio trabalho é aprimorada.

Colocando-me pessoalmente como exemplo desse tipo de formação profissional na universidade, pude confirmar que ao longo da minha graduação universitária como designer de produtos pela PUC-Rio em 2013, tive pouquíssimo contato com uma formação teórica, com professores que me fizessem questionar ou entender como funciona a estrutura social da indústria no Brasil, e como seria minha atuação profissional dentro de escritórios voltados para o desenvolvimento de produtos. De certo modo, nós, os alunos saímos do curso acreditando estarmos aptos a exercer nossa profissão, entretanto o mercado de trabalho é extremamente distante do que nos é inculcado. Nos locais de trabalho, espera-se do aluno de graduação em design um conhecimento técnico muito maior do que se almeja em relação ao pensamento crítico. É exigido que saibamos um pouco de cada ferramenta para ao fim do curso elaborarmos um projeto final sozinhos. Isto é, ao longo do último ano, nós alunos devemos desenvolver um produto com a orientação de um professor. Dentro deste processo devemos possuir a autonomia criativa de decidir o que exatamente queremos fazer, temos que ser autossuficientes também em fazer toda a pesquisa de mercado e similares do produto, necessitamos saber construir modelagens 3D em programas de computador além dos protótipos manuais, devemos ser aptos em fotografia de 
produto, em photoshop e em comunicação visual para criarmos a marca, o branding, a embalagem e se ainda sobrar tempo um vídeo promocional que sempre é muito bem visto.

Nossa crítica não é exatamente sobre a necessidade de dominarmos tecnicamente muitas ferramentas diferentes e de termos de aplicar esse conhecimento em um único projeto para que se avalie as aptidões do aluno, ou a estrutura empregada nessa proposta específica. Porém nos parece um tanto distante da realidade do mercado de trabalho que se domine superficialmente habilidades técnicas distintas, além da simulação de um desenvolvimento projetual totalmente autoral. Desse modo nos voltamos para responder a essa pulverização de conhecimentos e todos eles obrigatórios ao jovem designer trabalhando acerca do trabalho coletivo, que requer não apenas a setorização de funções, devido a uma necessidade real de especialização em alguma ferramenta e não um domínio parcial de muitas, mas também a subordinação a um 'patrocinador' do projeto.

Podemos compreender que a universidade e o mercado de trabalho operam de forma distintas. A transmissão do conhecimento técnico superficial é apenas uma apresentação das possibilidades dos setores onde o aluno eventualmente poderá atuar no mercado de trabalho, e que fica a cargo do aluno se especializar na sua área de interesse pessoal e conforme as demandas existentes. Nosso exame a respeito desse modelo de ensino não pretende invalidar o que é feito na parte técnica da formação do aluno, mas sim apontar a carência na formação intelectual, afinal se de fato não é possível que haja um aprofundamento em uma área específica, deveria ao menos haver uma discussão no campo teórico com fim de esclarecer ao aluno que a simulação de mercado do projeto final nada tem de similar com a forma que o designer de produto atuará no mercado de trabalho. Além disso, a divisão das fronteiras que discutimos ao longo desse texto nos parece mais nebulosa quando estamos dentro da universidade, pois somos levamos a crer na autonomia criativa do designer e na transposição da noção mítica da figura do artista para o designer.

Nos parece também incongruente que ao mesmo tempo em que se defende uma formação prática e se exija do aluno conhecimentos técnicos, exista uma concepção de que a produção de objetos tem qualquer relação com uma criatividade inata. Apesar dessa noção ser falaciosa também no Campo da Arte, é mais plausível que ela exista na produção da obra artística uma vez que para a 
maioria da população a função da arte é contemplativa. O conhecimento acerca da especulação financeira em torno da arte é constituído apenas entre as extrações de classes mais abastadas, que de fato fazem essas transações. Porém aplicar a noção de dom criativo a um designer que desenvolve uma cadeira vendida na Tok \& Stok por exemplo, nos parece extremamente ilógico. A metodologia projetual tal qual aprendemos na universidade tem como etapa a "pesquisa de mercado", seja lá o que isso possa significar. O fato é que ela contempla qual é o público-alvo que se quer atingir e qual o poder de compra desse eventual consumidor, assim como a análise de produtos similares, o desenvolvimento de inúmeras possibilidades de desenho, a prototipação do objeto, testes de ergonomia e resistência, variações de material, desenhos técnicos, enfim, uma gama de passos a serem seguidos que são pré-requisitos para a produção. Isto tudo sem mencionar que se o profissional é empregado em uma empresa e não um empreendedor, ainda existe o crivo de uma gerência a qual ele é subordinado que avalia questões financeiras essenciais para que a decisão do que será produzido seja tomada. Portanto, desde a idealização, concepção ou projeto de um objeto são necessárias análises financeiras e mercadológicas que irão, sem dúvida, interferir na forma e na função do produto final.

Ora, onde está então o fator criativo dentro desse desenvolvimento? Julgamos que além existir um treinamento para que se aprenda a projetar objetos, a questão estética é extremamente relativa. Tal qual na arte, mas de modo mais explícito sabemos que o juízo de gosto estético é fruto de uma inculcação social, que no caso do design de produtos é conduzido de forma ávida pelas empresas de marketing, pelas revistas de decoração de casas, e todo tipo de propaganda comercial. Consideramos um produto mais bonito do que outro porque fomos condicionados a pensar desta maneira ou entre os exemplares que nos apresentam. Não somos levados a pensar em coisas inexistentes, ou fora daquilo que foi produzido. Assim e da mesma forma que julgamos que um aparelho eletrônico é mais "intuitivo" porque estamos habituados a utilizá-lo, por exemplo, há quem prefira o sistema operacional da Mac do que do Windows para seus smartphones e computadores.

Isso que hoje nos parece um dado que beira a obviedade, era bastante turvo quando ainda éramos alunos da graduação. Nos foi ensinado que uma cadeira acolchoada e com encosto é mais confortável, mas nunca nos fizeram 
compreender que ela é apenas tida como "mais confortável" para nós ocidentais, posto que a noção de conforto é um arbitrário cultural e porque estamos habituados a esse tipo de cadeira, e que para os orientais essa percepção de conforto é diferente.

Entretanto, ironicamente uma cadeira nomeada de Favela dos Irmãos Campana, feita toda de sarrafos de madeira é tida como um produto de alto luxo e "valor agregado", tal como os profissionais de marketing gostam muito de dizer, apesar de estar muito distante do que se espera de nossa noção de conforto, e a argumentação para se justificar esse produto é a assinatura do projetista e não os tão mencionados fatores ergonômicos que teoricamente devem estar presentes em produtos pensados para melhorar a vida das pessoas. E para fundamentar esse tipo de incongruência, os pares de campo se debruçam na argumentação de que esses objetos de apelo estético e não funcionais são objetos com uma aura artística.

Mas o que é isso que é uma aura em uma obra de arte? Ou bem compreendemos a arte na forma romantizada como uma expressão individual e sentimental do artista, ou bem admitimos que existe uma reprodutibilidade industrial e um interesse financeiro no Campo da Arte também. Nos parece que dentro deste limbo na relação fronteiriça da arte e do design, o termo arte não se relaciona com a sua definição tradicional, mas é utilizado como um argumento justificativo para fabricação de objetos de luxo com pouco valor funcional. Se trata da legitimação do objeto a partir da biografia do criador, e não pelo objeto em si. De fato, quando se atinge (em qualquer profissão, tal como mencionamos o caso do futebol arte) um determinado reconhecimento onde não se depende mais da qualidade funcional e estética daquilo que é produzido por já haver uma aceitação prévia unicamente pelo fato de que quem projetou já possui um grau de legitimidade inquestionável, esse designer possui uma liberdade criativa muito maior do que seus colegas que trabalham dentro de padrões e regras mais engessados. E desse modo, quem consome esse tipo de objeto certamente não o faz esperando um retorno prático, mas sim por prestígio ou por uma distinção social, tal qual funciona o grande mercado de arte, no qual pessoas pagam verdadeiras fortunas por coisas que poderíamos questionar o valor agregado por diferentes razões. Podemos então estabelecer uma relação direta entre a caracterização de um objeto industrial como arte e deixar para a ação dos agentes legitimadores se encarregarem para que tal denominação ocorra. Então, em termos 
vulgares, compreendemos que a classificação artística em campos que não necessariamente são da arte, tem vínculo direto com a fama ou reconhecimento do designer autoral ou do artesão em questão. Quando se trata de "futebol arte" por exemplo, não estamos designando qualquer jogador, mas sim aqueles que têm destaque em relação a outros, e mesmo que por superioridade técnica, alcançaram um reconhecimento inquestionável, transmitindo assim a noção de excepcionalidade em relação aos demais.

Quando anteriormente apresentamos exemplos da banalização da palavra design, e seu uso para configurar uma noção superficial do campo, uma noção que se interessa apenas pelas razões estéticas de um produto ou serviço, não podemos deixar de mencionar que o mesmo ocorre com o objeto de arte. Do mesmo modo que design legitima uma configuração ou uma forma entendida como "melhor", "mais acabada" ou mais "bem-feita", arte traz uma compreensão de uma prática possuidora de uma aura especial, não acessível a toda ou qualquer pessoa. Envolve implicitamente toda a noção já debatida em relação a criatividade, talento e dom, o que nos leva a crer em uma designação inata do produtor. Podemos fazer essa análise sob diferentes aspectos, no cinema por exemplo, não são todos os diretores que fazem filmes que consideramos artísticos, bem como não classificamos artisticamente qualquer cantor ou ator, tendemos a acreditar que existem uns que realizam trabalhos de arte e outros não. Entretanto nos parece um tanto confuso defender o porquê da crença artística presente em alguns trabalhos ou pessoas e outros não, o que nos faz voltar a justificativa do dom inato defendida pelos pares do Campo da Arte, ou pelo menos os defensores da noção romântica recorrente no campo.

Nos parece que os reais motivos para a permanência dessas noções estão presentes na forma pela qual o mercado opera com a legitimação de indivíduos e como ele nos faz crer na superioridade de algo em relação aos demais. Além disso podemos constatar que existe uma tendência ou um habitus a se configurar como artístico os trabalhos com maior erudição, dentro é claro daquilo que compreendemos por erudito na cultura ocidental moderna. Assim, voltando a ideia de erudição e cultura, tal qual foi defendido por Canclini, podemos relacionar então a cultura com o que entendemos enquanto arte.

Quando se legitima algo ou alguma coisa como artístico, está se assegurando também o pertencimento ao mercado capitalista, mas entendido ou 
camuflado como cultural ou pertinente à cultura. A arte nos é apresentada como um dos pilares que forma aquilo que se tem como cultura hoje. Mas então, se a arte é tida como resultado de um dom inato, por que tendemos a valorizar em maior grau aqueles artistas que possuem um conhecimento técnico mais elevado? Isto é, a arte assistemática ou popular, não é vista sob a mesma ótica da arte erudita, tida como superior. Produtos populares são comercializados por valores menores, bem como seu reconhecimento simbólico é reduzido em relação à arte erudita. Um músico da orquestra sinfônica não é entendido ou respeitado socialmente do mesmo modo que um tocador de sanfona do sertão de Alagoas, mesmo que ambos possuam o domínio de seu instrumento, assim como não assistimos a uma ópera de modo igual ao que assistimos uma apresentação de um repentista nordestino, ou um cantor de funk nos morros cariocas. Se desejamos debater porque entendemos hegemonicamente que existe mais arte em determinados lugares do que em outros, precisamos inicialmente atentar para a hipocrisia de que considerarmos que a prática artística é fruto apenas de um talento criativo, quando socialmente o valor da técnica, da prática e do treinamento é inegavelmente considerado quando rotulamos o que é de fato é arte ou não, afinal existe uma diferenciação de status social quando tratamos de cultura e cultura popular, onde uma tem mais valor simbólico que a outra.

Ao longo de nosso trabalho tecemos uma breve consideração acerca do estudo universitário da arte e do design, e argumentamos sobre a falta de um conhecimento prévio adequado por parte do aluno que deseja cursar uma dessas carreiras. Essa noção equivocada sobre ambas as profissões se dá também pela forma leviana que empregamos as palavras arte e design para caracterizar o juízo de valor estético, camuflando assim a real atuação profissional no mercado que é de fato quem exige treinamento e técnica e quem estipula um regulamento firme no desenvolvimento de ideias e projetos. E, para além da expectativa superficial do que foi ministrado nesses cursos universitários, nos deparamos com o dado de que as próprias formações nas áreas perpetuam um ensino que pouco esclarece como se dá o exercício verídico da profissão no Brasil.

A falta de uma formação teórica mais representativa é uma das causas que engendra a falta de uma formação de pensamento crítico, ou que se constitua a prática de realizar a análise de objetos como separados do mundo, isto é, sem que haja uma reflexão política, histórica, econômica e social, o que é fundamental para 
entendermos a lógica do mercado consumidor no capitalismo, e assim refletirmos o porquê e para quem estamos produzindo bens de consumo.

Vale frisar que pudemos comprovar que a supervalorização da estética dos objetos industriais também nos oferece espaço para que haja a sobreposição das fronteiras que dividem os campos, isto é, um objeto legitimado como belo, independente das suas funções práticas, está mais propício a estar no limite da separação entre design e arte ou artesanato e arte. Subentende-se que o objeto artístico possui algo de valor contemplativo, mas quando os agentes legitimadores definem um objeto artesanal ou um objeto industrial como arte, cria-se um equívoco classificatório, fato esse que leva muitas pessoas a entenderem o design e o artesanato como um apêndice da arte. Mesmo dentro das escolas de design e nos discursos dos pares do campo, podemos encontrar com facilidade esse tipo de comparação, que consequentemente esse foi um dos fatores pelo qual comprovamos a existência de uma grande distância entre o ensino universitário e o mercado de trabalho, daí uma das razões para se refletir acerca da grande quantidade de alunos formados e que não exercem a profissão, tanto por se depararem com a realidade do mercado, que põe fim a uma expectativa em uma autonomia criativa, quanto pela demanda de profissionais menor do que a oferta $\mathrm{e}$ pelo despreparo com que os alunos deixam o curso para exercer sua carreira.

Uma convicção que pudemos depreender de nosso estudo foi a outra característica dos cursos de formação em design, pois eles evidenciam que majoritariamente a realidade dos designers famosos, que são os profissionais que já detêm uma maior liberdade na elaboração de projetos, por já terem passado pelo processo de legitimação e dessa forma possuírem maior autonomia ou mais capital simbólico. Assim, não nos parece claro como é a relação de trabalho dos demais designers, que precisam prestar contas aos chefes e não elaborar projetos a partir de um briefing mais pessoal. Logo, o distanciamento com o que se almeja e o que se tem na maioria do mercado de trabalho acaba por ser muito grande, o que também é um fator chave para que hoje uma opção comum dos designers recémformados é abrir uma própria microempresa. Ademais, o trabalho autônomo do designer assegura uma maior liberdade projetual em relação ao trabalho na indústria.

Analisar quem criou as demandas dessas mercadorias é também uma ferramenta teórica para compreendermos o mercado de bens de consumo com mais 
clareza, e fundamental para a sustentação de que a prática criativa não é algo que se dá internamente e é absorvido pela sociedade, mas sim o contrário. Não existe criação se não há uma demanda de consumo, isto é, um dono de empresa não investirá na produção de algo que não julgue vendável. Do mesmo modo, que não parece razoável que um artista plástico que desenvolve obras que não correspondam à expectativa do mercado possa manter a sua produção, pois é evidente que terá dificuldade de sobreviver do seu trabalho. Por mais que o profissional em questão tenha uma autonomia maior a de um subalterno em uma indústria, isto é, que ele seja dono do próprio negócio ou que tenha um ateliê individual para desenvolver projetos de arte, existe um briefing implícito, o que podemos entender como a demanda de mercado preexistente por conta do modo de produção capitalista.

O que está se consumindo no mundo é a resposta para o que se deve fabricar para que se tenha uma maior possibilidade de êxito de venda, caso contrário dificilmente esse objeto irá se estabelecer ou possuir uma existência no conjunto dos objetos da cultura material. Logo, defender uma expressão individual pura é um tanto equivocado, seja para artistas, seja para designers. Vivemos em uma sociedade extremamente determinada pelo individualismo, nós nos acreditamos como sujeitos únicos, que detemos gostos e ideologias próprias e que julgamos desenvolver sozinhos a civilização, tal como Robson Crusoé, a partir de uma caixa de ferramentas e da nossa biografia individual. Essa crença vai além das aspirações artísticas manifestadas por algumas pessoas, de modo geral, existe a percepção que aquilo que vestimos, que comemos, a música que escutamos, os livros que lemos e todas as nossas ações, sejam elas voltadas direta ou indiretamente para um consumo de bens e modelos de comportamento, são tidas como expressões individuais e que desse modo temos o livre arbítrio das nossas escolhas. Em nosso trabalho não defendemos que exista algum modelo de pressão ditatorial explícito que nos molda a ser conforme a imposição de um poder diretamente opressor, mas nos parece inequívoco que existe uma predisposição social prévia, um habitus, que nos empurra para sermos aquilo que somos.

O que tivemos a intenção de defender foi uma reflexão aprofundada de como o mercado consumidor nos propõe formas de consumo pré-estruturadas, ou seja, nos dá algumas opções de comportamento social e que seguimos acreditando em uma autonomia de liberdade absoluta de escolha. Consumimos o que existe no 
mundo para ser consumido, nossos gostos pessoais provêm daquilo que nos é inculcado a gostarmos, assim como nosso paladar é constituído socialmente, como construímos nossa noção de conforto, como passamos a acreditar no amor romântico como alguma coisa mais ou menos intuitiva. Enfim, desejamos evidenciar que a noção de individualidade ou de liberdade é arbitrária e que os valores que acreditamos piamente ou que a partir daí o exercermos, não é assim tão autônomo. Procuramos indicar que muitas são as ferramentas instituídas na nossa sociedade e que nos condicionam sem que percebamos com clareza. Elas nos impõem um comportamento social, sem falar que atualmente a crença na individualidade é algo crescente devido as mudanças nas formas de comunicação que vem sendo implementadas com o uso das tecnologias digitais (internet). Desde as mais explícitas, tal como o marketing, onde é nítido a intencionalidade de manipulação, até atuações mais sutis como nos filmes, na música, nos livros, ou nas escolas, estamos sofrendo influências para a construção de um comportamento que nos fazem repetir padrões de consumo e gosto.

Esse foi o eito, que empregamos para constatar que a crença na individualidade não é apenas voltada para a prática criativa, mas é também um importante elemento comportamental e social. Somos condicionados a nos acreditarmos autônomos e independentes nas nossas escolhas, quando na verdade a todo momento estamos sob influência não apenas das indústrias, mas também do Estado, que se inclina ao poder e vontade das indústrias. A visão romântica de liberdade está presente em todos os indivíduos, seja no trabalho ou na vida social.

Desse modo agrupamos para essa conclusão algumas das defesas formuladas ao longo deste trabalho em um mesmo conjunto, cujo o mote comprovou o desencadeamento das noções hegemônicas presentes na sociedade e que tiveram como ponto inicial a crença na autonomia. Entender o artista como gênio, o designer como criativo e o artesão como proprietário de um saber ancestral se associam à noção de consumo como expressão do individualismo, e a coletividade no trabalho como não pertencente em todas as áreas. O que podemos concluir acerca das fronteiras entre o Campo da Arte, o Campo do Design e o Campo do Artesanato é que os fatores determinantes para que essa separação se dê são flexíveis e variantes. Podemos apontar oposições na produção, na comercialização, nos tipos de representação simbólica, no público consumidor e entre os autores dos objetos em questão. Logo, as distinções entre os 
campos estabelecem alguns padrões específicos para estes modelos de produção criativa. Da mesma forma, os pontos intercessores os colocam próximos enquanto profissionais produtores e objetos, por exemplo quando tratamos da noção da criatividade, autonomia e individualidade de quem produz. A dificuldade que encontramos em mapear essas fronteiras é o fato de que essas concepções não são engessadas em uma fórmula exata de produção, circulação e consumo. Agregar legitimação e reconhecimento a determinados produtos, é o fator que os movimenta de um Campo para outro, e desse modo se altera a percepção simbólica sobre eles, os produtos, por parte do público e dos pares, além de modificar também seu valor financeiro.

Analisar o objeto dentro de seu contexto histórico e social é a ferramenta fundamental para compreendê-lo dentro da sociedade. Nós, como pesquisadores do Campo do Design, estamos convictos de que é necessário que se estabeleçam as análises de mercadorias dentro desses moldes, para que assim possamos inseri-las corretamente dentro da estrutura social da sua época. Isso nos tem valor teórico enquanto discussão acerca dos padrões de consumo e para a compreensão de como ele se dá. Uma vez que isso se torna claro para nós, se expande a nossa capacidade de fomentar um pensamento crítico como pesquisadores e como projetistas de objetos.

Nossa hipótese inicial se baseava no desejo de investigar e decifrar as fronteiras muitas vezes imperceptíveis entre design, arte e artesanato. Ao longo do processo de construção desta dissertação, nos deparamos com noções inéditas para nós, que acabaram por guiar a pesquisa por caminhos não previstos. Tanto as entrevistas com produtores diferentes, quanto o aprofundamento teórico, nos provaram como é necessário que sejamos flexíveis quanto aos nossos pontos de argumentação, pois estamos sempre nos transformando enquanto seres sociais que somos. Assim, concluímos que como nós, as fronteiras também não são engessadas, e determinarmos regras rígidas para separar os campos torna-se um equívoco, ou um ato prepotente. Depois desse mapeamento dos pontos que são capazes de evidenciar quando eles se aproximam ou quando se afastam, o Campo do Design, do Campo da Arte e do Campo do Artesanato, pode ser mais bem definido. Procuramos apresentar quais os aspectos são capazes de modificar simbolicamente o pertencimento de um objeto em uma categoria e transportá-lo para outra. Por fim, como uma conclusão pessoal, pudemos compreender que 
existem meios de se classificar a separação de fronteiras em linhas gerais, entretanto para que se faça um estudo aprofundado de um objeto não há uma fórmula exata para aplicarmos nessas distinções. É sempre necessária uma investigação atenta e compreensiva para se entender essas divisões que se modificam de um objeto para outro, ou de um produtor para outro, afinal as fronteiras são elásticas. 


\section{Referências bibliográficas}

BEZERRA, J.; REGINATO; L. Mangue beat: Guitarras e Alfaias da Lama do Recife para o Mundo. 1ª Edição. São Paulo: Panda Books, 2017.

BONSIEPE, G. Design: Como Prática de Projeto. 1르로ao. São Paulo: Blucher, 2012.

BOURDIEU, P. Un art moyen: Essai sur les usages sociaux de la photgraphie. Paris: Minuit, 1965.

BOURDIEU, P. A Produção da Crença: Contribuição para uma Economia dos Bens Simbólicos. 3를 Edição. Porto Alegre: Editora Zouk, 2005.

BOURDIEU, P. A Distinção: Crítica social do julgamento. 2ª Edição. Porto Alegre: Editora Zouk, 2006.

CANCLINI, N. G. As Culturas Populares no Capitalismo. 1를 Edição. São Paulo: Editora Brasiliense S.A, 1982.

CANCLINI, N. G. Diferentes, Desiguais e Desconectados: Mapas da Interculturalidade. 1를 Edição. Rio de Janeiro: Editora UFRJ, 2005.

CANCLINI, N. G. A Sociedade sem Relato: A Antropologia e Estética da Iminência. 1를 Edição. São Paulo: EDUSP, 2012.

CANCLINI, N. G. La Producción Simbólica: Teoría y Método em Sociología del Arte. 10ª Edição. Buenos Aires: Siglo Veintiuno Editores, 2014.

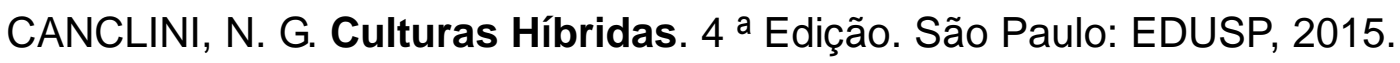

CIPINIUK, A. Design: O livro dos Porquês - O Campo do Design Compreendido como Produção Social. 1를 Edição. Rio de Janeiro: Editora PUC-RIO, 2014.

ELIAS, N. A sociedade dos indivíduos. Tradução: Vera Ribeiro. Rio de Janeiro: Jorge Zahar Editora, 1994. 
ESCOBAR, T. El Mito del Arte y el Mito del Pueblo: Cuestiones Sobre Arte Popular. 1를 Edição. Buenos Aires: ARIEL, 2014.

FORTY, A. Objetos de Desejo. 1를 Edição. São Paulo: COSAC NAIF, 2007.

GRAEBER, D. On the Phenomenon of Bullshit Jobs: A Work Rant. 2013. https://strikemag.org/bullshit-jobs/ acesso em: 20/09/2018

KANT, I. Crítica da Razão Pura. Tradução: Manuela Pinto e Alexandre Morujão. 5ª Edição. Lisboa: Fundação Calouste Gulbenkian, 2001.

MARX, K. Grundrisse. Rio de Janeiro: Editora UFRJ, 2011.

MATIAS, I. Projeto Revolução; Do Fetichismo a Gestão, uma Crítica a Teoria do Design. 1 Edição. Florianópolis: Editora em Debate, 2014.

SENNETT, R. O Domínio do Homem Público. 1ª Edição. Rio de Janeiro: Editora RECORD, 2014.

SUASSUNA, A. 0 auto da Compadecida. $39^{\circ}$ Edição. Rio de Janeiro: Editora Nova Fronteira, 2018.

TELES, J. Do Frevo ao Mangue Beat. 1를 Edição. São Paulo: Editora 34, 2000.

THORTON; S. Sete dias no Mundo da Arte. São Paulo: AGIR, 2010.

VARAZZE, J. de. Legenda Áurea. São Paulo: Companhia das Letras, 2003. VASARI, G. Vida dos artistas. São Paulo: Editora Martins Fontes, 2011.

WOLFF, J. A Produção Social da Arte. 1를 Edição. Rio de Janeiro: ZAHAR Editores S.A, 1981. 